Заснований

y 2009 p.

Свідоцтво про державну реєстрацію друкованого засобу масової інформації

Серія КВ № 15436-4008 ПР

22 червня 2009 p.

Адреса редакції:

Україна, 69600,

м. Запоріжжя, МСП-41,

вул. Жуковського, 66

Телефон

для довідок:

(061) 228-75-26

Факс: (061) 228-75-26

\section{Вісник}

\section{Запорізького національного університету}

\section{Юридичні науки}

№ 2, 2019

Запоріжжя 2019 
DOI Вісник Запорізького національного університету: Збірник наукових праць. Юридичні науки https://doi.org/10.26661/hznuj-2616-9444

DOI № 2/2019

https://doi.org/10.26661/hznuj-2019-2-98

Вісник Запорізького національного університету: Збірник наукових праць. Юридичні науки. Запоріжжя: Запорізький національний університет, 2019. № 2. 101 с.

Рекомендовано до друку та поширення через мережу Internet вченою радою ЗНУ (протокол засідання № 4 від 26.11.2019 р.)

Згідно з Постановою Президіїі ВАК України № 1-05/1 від 10.02.2010 р.; Наказ МОН України № 1528 від 29.12.2014 р. збірник внесений до переліку наукових фахових видань (юридичні науки).

Вісник Запорізького національного університету: Збірник наукових праць. Юридичні науки внесено до Міжнародної науково метричної бази даних «Index Copernicus International» (Польща) (з 1 січня 2015 р.).

\section{РЕДАКЦЙНА РАДА:}

Головний редактор

- Коломоєць Т.О., доктор юридичних наук, професор

Заступник головного редактора - Колпаков В.К., доктор юридичних наук, професор

Відповідальний редактор

- Верлос Н.В., кандидат юридичних наук, доцент

\section{РЕДАКЦІЙНА КОЛЕГІЯ:}

Биргеу М. М.

Болокан I. B.

Бондар О. Г.

Галіцина Н. В.

Дугенець О. С.

Ібрагімов С. I.

Курінний Є. В.

Кушнір С. М.

Сильченко М. В.

Уільям Дж. Уоткінс

Федчишин Ю. А.

Шарая А. А.
- доктор юридичних наук, професор (Республіка
Молдова)

- доктор юридичних наук, доцент

- доктор юридичних наук, доцент

- доктор юридичних наук, доцент

- доктор юридичних наук, професор (Російська Федерація)

- доктор юридичних наук, професор (Республіка Таджикистан)

- доктор юридичних наук, професор

- доктор юридичних наук, доцент

- доктор юридичних наук, професор (Республіка Білорусь)

- доктор юридичних наук (Південна Кароліна, США)

- кандидат юридичних наук, доцент

- кандидат юридичних наук, доцент 


\section{MICT}

\section{РОЗДІЛ І. АКТУАЛЬНІ ПИТАННЯ ТЕОРІЇ ТА ІСТОРІЇ ДЕРЖАВИ І ПРАВА}

Середа А. М.

НАСТУПНІСТЬ КРИМІНАЛЬНОГО СУДОЧИНСТВА

В УКРАЇНІ В ПЕРІОД ХVII-ХІХ СТ.

РОЗДІЛ ІІ. ЗЕМЕЛЬНЕ ПРАВО; АГРАРНЕ ПРАВО;

ЕКОЛОГІЧНЕ ПРАВО; ПРИРОДОРЕСУРСНЕ ПРАВО

Бондар О. Г., Луц Д. М.

СУЧАСНИЙ СТАН ПРАВОВОГО РЕГУЛЮВАННЯ ОРГАНІЧНОГО

ТВАРИННИЦТВА В УКРАЇНІ: АКТУАЛЬНІ ПРОБЛЕМИ 16

РОЗДІЛ ІІ. ЦИВІЛЬНЕ ПРАВО ТА ЦИВІЛЬНИЙ ПРОЦЕС; МІЖНАРОДНЕ ПРИВАТНЕ ПРАВО

Алімов К. О., Щипанова О. О.

НОРМАТИВНИЙ АНАЛІЗ РЕАЛІЗАЦІЇ ПРИНЦИПУ ГЛАСНОСТІ

В ЦИВІЛЬНОМУ СУДОЧИНСТВІ УКРАЇНИ. 26

Самойленко Г. В.

ГАРАНТІЇ ПРАВ ПАСАЖИРА ЗА ДОГОВОРОМ ПЕРЕВЕЗЕННЯ ПАСАЖИРА 34

Ткалич М. О.

TO THE QUESTION OF DEFINING THE CONCEPT OF "SPORT"

UNDER THE LEGISLATION OF UKRAINE

РОЗДІЛ ІV. АДМІНІСТРАТИВНЕ ТА ФІНАНСОВЕ ПРАВО

Коломоєць Т. О., Кушнір С. М.

ІНСТРУМЕНТАРІЙ «КАБІНЕТНОГО ДОСЛІДЖЕННЯ»: ЧИ ВДАЛОЮ

С НОВА ЗАКОНОДАВЧА МОДЕЛЬ МОНІТОРИНГУ СПОСОБУ ЖИТТЯ? 49

Пирожкова Ю. В.

НАБУТТЯ ПРАВА НА ПРИВАТНУ ДЕТЕКТИВНУ (РОЗШУКОВУ) ДІЯЛЬНІСТЬ

В УКРАЇНІ: ДЕЯКІ ДИСКУСІЙНІ ПИТАННЯ ПЕРСПЕКТИВНОЇ РЕГЛАМЕНТАЦІЇ.. 55

\section{РОЗДІЛ V. КРИМІНАЛЬНИЙ ПРОЦЕС ТА КРИМІНАЛІСТИКА; ОПЕРАТИВНО-РОЗШУКОВА ДІЯЛЬНІСТЬ}

Войтович Є. М.

ЩОДО ТРИВАЛОСТІ ПОВНОВАЖЕНЬ СЛІДЧОГО СУДДІ

В КРИМІНАЛЬНОМУ ПРОВАДЖЕННІ 63 
Сна I. B.

ПРОБЛЕМНІ ПИТАННЯ ПРОВЕДЕННЯ СЛІДЧИХ (РОЗШУКОВИХ) ДІЙ, ЯКІ СУПРОВОДЖУЮТЬСЯ ВИЛУЧЕННЯМ ЕЛЕКТРОННИХ НОСЇ̈В ІНФОРМАЦЇ̈.

Ларкін М. О.

ОСОБЛИВОСТІ ДОПИТУ ПІДОЗРЮВАНОГО -

ЧЛЕНА МОЛОДІЖНОЇ НЕФОРМАЛЬНОЇ ГРУПИ (ОБ 'СДНАННЯ)

ПІД ЧАС ДОСУДОВОГО РОЗСЛІДУВАННЯ.....

Мельковський О. В.

ВНУТРІШНІ ТА ЗОВНІШНІ ЗАГРОЗИ БЕЗПЕЦІ ДІЯЛЬНОСТІ

ВИЩОГО НАВЧАЛЬНОГО ЗАКЛАДУ: ТЕОРЕТИЧНІ ТА ПРАКТИЧНІ АСПЕКТИ.

80

Сінєльнік Р. В.

ВТРУЧАННЯ В ДІЯЛЬНІСТЬ СУДОВИХ ОРГАНІВ ЯК СПРОБА ПОСЯГАННЯ

НА ПРИНЦИП НЕЗАЛЕЖНОСТІ СУДОВОЇ ГІЛКИ ВЛАДИ В УКРАЇНІ 86

ІНФОРМАЦІЙНА ДОВІДКА ПРО АВТОРІВ

99

ВИМОГИ ДО ОФОРМЛЕННЯ СТАТЕЙ У “ВІСНИК ЗАПОРІЗЬКОГО

НАЦІОНАЛЬНОГО УНІВЕРСИТЕТУ” (СЕРІЯ „ЮРИДИЧНІ НАУКИ”) .

100 


\section{CONTENTS}

\section{SECTION I. TOPICAL ISSUES OF THEORY AND HYSTORY OF STATE AND LAW}

Sereda A. N.

SUCCESSION OF CRIMINAL PROCEEDINGS IN UKRAINE

DURING XVII-XIX CENTURIES

\section{SECTION II. LAND LAW; AGRARIAN LAW; ENVIRONMENT LAW; NATURAL RESOURCES LAW}

Bondar O. G., Luts D. M.

THE CURRENT STATE OF LEGAL REGULATION OF ORGANIC

ANIMAL BREEDING IN UKRAINE: ACTUAL PROBLEMS.

SECTION III. CIVIL LAW AND CIVIL PROCEDUR; FEMILY LAW; INTERNATIONAL PRIVATE LAW

Alimov K. O., Shchypanova O. O.

REGULATORY ANALYSIS OF REALIZATION OF THE PRINCIPLE OF GLASSES IN THE CIVIL COMMISSION OF UKRAINE.

Samoylenko G. V.

PASSENGER RIGHTS GUARANTEES UNDER THE CONTRACT OF CARRIAGE OF THE PASSENGER.

Tkalych M. O.

TO THE QUESTION OF DEFINING THE CONCEPT OF "SPORT"

UNDER THE LEGISLATION OF UKRAINE

SECTION IV. ADNINISTRATIVE AND FINANCIAL LAW

Kolomoiets T. O., Kushnir S. M.

TOOLS SET OF "DESK RESEARCH”: IS THE NEW LEGISLATIVE MODEL

OF LIFESTYLE MONITORING MODEL SUCCESSFUL?

Pyrozhkova J. V.

ACQUISITION OF THE RIGHT TO PRIVATE DETECTIVE (SEARCH)

PRACTICE IN UKRAINE: SOME DISCUSSIONS ON PERSPECTIVE REGULATION. 55

\section{SECTION V. CRIMINAL PROCEDURE AND CRIMINOLOGY; OPERATIONAL SEARCH ACTIVITY}

Voitovich E. M.

CONCERNING THE DURATION OF THE POWERS OF THE INVESTIGATING

JUDGE IN CRIMINAL PROCEEDINGS. 63 
Yena I. V.

PROBLEMS OF ISSUES OF THE INVESTIGATIVE (DEFINITIVE)

ACTIONS THE EXTRACTION OF ELECTRONIC MEDIA

Larkin M. A.

FEATURES OF THE INTERROGATION OF THE SUSPECTED MEMBER

YOUTH INFORMAL GROUP (ASSOCIATION) DURING

THE PRE-TRIAL INVESTIGATION.

Melkovskiy O. V.

INTERNAL AND EXTERNAL THREATS TO SAFETY OF ACTIVITY OF HIGHER EDUCATIONAL ESTABLISHMENT: THEORETICAL AND PRACTICAL ASPECTS

Sinielnik R. V.

INTERVENTION IN THE ACTIVITIES OF JUDICIAL AUTHORITIES HOW TO TAKE ACHIEVEMENT OF THE INDEPENDENCE

OF THE JUDICIAL BRANCH OF POWER IN UKRAINE. 86

INFORMATIONAL REFERENCES ABOUT THE AUTHORS . 99

THE REQUIREMENTS TO THE ARTICLES' REGISTRATION

IN THE "ZNU JOURNAL” (SERIES “LEGAL SCIENCES”). 100 


\section{РОЗДІЛ І. АКТУАЛЬНІ ПИТАННЯ ТЕОРІЇ ТА ІСТОРЇ̈ ДЕРЖАВИ І ПРАВА}

УДК 343.1(477)(091)»16/18»

DOI https://doi.org/10.26661/2616-9444-2019-2-01

\section{Наступність кримінального судочинства в Україні в період XVII-XIX ст.}

Середа А. М.

Запорізький національний університет, вул. Жуковського, 66, м. Запоріжжя, Украӥна

sereda.angela@ukr.net

\section{Ключові слова:}

кримінально-прочесуальне

право, суб'єкти кримінально-

прочесуальних відносин,

судова система, кримінальне

судочинство.

Надійшло до редколегії:

20.08.2019

Прийнято до друку:
У статті на основі аналізу нормативно-правових актів досліджено розвиток кримінально-процесуального права та функціонування його суб'єктів. Розкрито структуру та механізм складових елементів кримінально-процесуального права, особливості провадження судочинства.

\section{Succession of criminal proceedings in Ukraine during XVII-XIX centuries}

\section{Sereda A. N.}

Zaporizhzhya National University, str. Zhukovskogo, 66, Zaporizhzhya, Ukraine sereda.angela@ukr.net

Key words: criminal procedure law, subjects of criminal procedure relations, judicial system, criminal proceedings.
The Hetmanate trial in the eighteenth century generally retained the basic features of previous periods. But Russia's intensified interference in Ukraine's internal affairs, and in particular its judiciary, has made some changes. The Ukrainian competitive process with its simplicity, democracy and accessibility is gradually being supplanted by the inquisition process. However, it should be noted and positive changes in the judiciary Hetmanate. Thus, the legislation provides for a number of cases where a criminal case is initiated by the judicial authorities and without the victim's complaint. Thus, the criminal process of the Hetmanate becomes public.

In the courts of the Russian Empire and Russian Ukraine in the first half of the XIX century the trial was secret, the public was not allowed to sit in court. In addition, the legal regulation of the production of major investigative actions during the imperial period changed primarily in the form of fixing the relevant criminal procedural rules until 1832, which were located in many different legal acts, and since 1832 they were grouped in Book II of the Code of Criminal Code, but generally with changes of a more democratic 
nature, as evidenced above all by the existence of rules that guarantee certain procedural rights of suspects and accused, the requirements of humane treatment of them, including the direct prohibition of using physical influence, as well as more detailed regulation of the Institute for the Protection of Suspects and Accused.

Subsequently, the defendants' complaints of non-privileged states were admitted to the senate for sentences of corporal punishment and exile to settlements or to hard labor, but complaints could only be submitted after enforcement of the sentence. In the case of unjustified complaint, the convicted person was punished by corporal punishment, and if the complaint was found to be justified, the senate renewed the convicted person in his rights; at the same time determined him the compensation for the punishment incurred and imposed penalties on those who had been sentenced.

The trial was conducted in writing; the court ruled on the basis of the recordings of witnesses, defendants, experts and other written documents recorded in the minutes. On the basis of written protocols, the court decided the fate of the accused on strictly formal rules of assessment of evidence. The process remained inquisitive; torture was applied to the defendants during the trial in order to obtain a guilty plea (although torture had been prohibited in criminal proceedings since 1801). The decisions of the lower courts were necessarily sent for approval by the higher courts. In individual cases (mainly concerning nobles), the judgment of the court, after hearing the case in several courts, was reported to the king, on whom the final decision depended.

\begin{abstract}
Однією 3 форм захисту прав i свобод людини $\epsilon$ кримінальне судочинство. Фактично особливості кримінального правосуддя, становище людини в ньому $\epsilon$ чи не основними чинниками, на підставі яких відрізняють демократичну, правову державу від
\end{abstract} тоталітарної.

Складні соціальні системи, зокрема такі, як кримінальне судочинство, для їх глибокого розуміння повинні аналізуватися щодо історичного розвитку.

Важливим чинником необхідності звернення саме до історії $€$ наявність складнощів та протирічь, якими супроводжувався процес формування кримінально-процесуального права української державності та які проявлялися у формуванні та розвитку системи судочинства. Історико-правове дослідження кримінального процесу дає змогу виявити й систематизувати набутий досвід у реформуванні цієї галузі права, визначити його позитивні сторони та недоліки, а головне, виявити певні закономірності генезису вітчизняного кримінально-процесуального права, корисні для сучасності та майбуття.

Теоретичну основу дослідження складають положення, що містяться в дослідженнях правників, істориків тощо. Свій внесок у розроблення зазначеної проблеми здійснили, зокрема, такі дореволюційні автори, як І. Гессен, В. Даневський, Г. Джаншиєв, А. Коні,

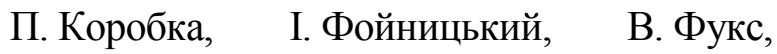
М. Холєв. Серед сучасних правників слід відзначити Р. Стецюка, Н. Сизу, В. Землянську, І. Полякова, В. Рум'янцева, О. Ярмиша. Вагомий внесок у дослідження зазначеного питання зробили такі українські історики права, як В. Горобець, В. Срмолаєв, І. Ісаєв, С. Кудін, Я. Падох, А. Рогожин, І. Сафронова, М. Страхов, I. Усенко.

Мета статті полягає в тому, щоб на
основі 2 аналізу
процесуального законодавства та наукових досліджень дослідити тенденції розвитку кримінального судочинства на 
українських землях, виявити етапи цього процесу, принципи кримінального судочинства.

Отже, кримінальний процес має свою історію розвитку. Треба зазначити, що еволюція судочинства була пов'язана 3 рівнем розвитку суспільства, держави й права, тому задля систематизації та більшої планомірності викладу зазначеної проблеми необхідно виокремити основні періоди становлення та розвитку кримінального процесу.

Так, аналізуючи князівський період IX - XIV ст., посилаємось на збірник норм староруського права «Руська правда», де вперше згадується про порядок судового розгляду та вирішення кримінальної справи. Згодом у Поширеній редакції Руської Правди виокремлюються норми процесуального права та правила безпосереднього судочинства. Отже, треба зазначити, що загалом судочинство періоду Київської Русі не відзначалося жорстокістю ні в здобутті доказів, ні в покаранні [1].

Другий

литовсько-польський період XIV - XVII ст. забезпечує судочинство збірником литовського кримінально-процесуального права, а саме «Судебником Казимира IV», збірниками магдебурзького права та Статутами Великого князівства Литовського 1529 р., 1566 р. та 1588 р., які присвячені суду й судовому процесу.

Необхідно відзначити, що в зазначені періоди саме принципи кримінального процесу були закріплені в законі, а панівними в державі були політичні та правові ідеї щодо завдань i способу здійснення судочинства в кримінальному провадженні, що визначають спрямованість i побудову кримінального процесу загалом, форму та зміст його стадій та інститутів, порушення яких обов'язково тягне до скасування вироку та інших рішень у справі.

Саме принцип правової рівності в кримінальному процесі встановлював Перший Литовський Статут 1529 р., який поширював свою дію на українські землі за часів їх перебування у складі Литви. Після об'єднання Польщі та Великого Князівства Литовського в єдину федеративну державу, а саме Річ Посполиту, на українських землях, що ввійшли до цього об'єднання, поширювали свою дію Литовські статути 1566 р. та 1588 р., за якими кримінальний процес був переважно змагальним, отже, рівність сторін під час провадження справи в суді мала місце [2].

Українському середньовічному процесу була властива станова нерівність. Формалізм судочинства був пережитком обвинувального змагального процесу. Особливістю судового процесу українських земель XVI ст. був дуалізм процесів, а саме загального та звичаєвого.

Так, копне судочинство здійснювалося на засадах рівності учасників процесу, усності та широкої участі громадськості в розгляді справи та прийнятті рішення. Статути 1529 р., 1566 p. закріпили недопустимість заочного покарання та неможливість піддати шляхтича арешту та ув'язненню без вироку суду [2].

Необхідно звернути увагу на появу професійних суддів - знавців права. Строката система численних судових чиновників-асистентів судді, яка почала формування ще за часів Київської Русі, згодом впорядковується, припиняється дублювання функцій судових чиновників, з'являється професійне судове чиновництво. Держава починає дбати про безпеку членів суду.

Крім того, була вже відтворена система як правових, так і позаправових судових доказів, які походили зі звичаєвого права. Правовими доказами були власне зізнання, свідоцькі показання, письмові документи. Визнавалися також позаправові докази («ставення шапки», «викидщина»), але в разі їхнього пред'явлення суд вимагав підкріплення доказами правовими. Особливе місце в системі позаправових доказів посідали присяга та зіставлення голінок 
(практикувалося в копних судах у виняткових випадках).

Отже, судовий процес засновувався на давньоруському походженні, а його еволюція була зумовлена суспільнодержавним розвитком князівства. Хоча вона відбувалася повільніше, ніж еволюція судової системи, пореформений процес якісно відрізнявся від дореформеного.

Третій козацько-гетьманський період XVII - XVIII ст. врегульовує оригінальну судову систему й процес, які існували в Запорізькій Січі та Гетьманщині.

Так, судочинство здійснювалося в Запорізькій Січі відповідно до норм звичаєвого права. Одним із найважливіших принципів козацького правосуддя була рівність усіх козаків перед судом. Процес за своїм характером був обвинувально-змагальним.

В результаті національної революції XVII ст. було створено незалежну державу, яка мала судову систему й судочинство, які існували протягом багатьох десятиліть після входження Гетьманщини до складу Росії.

До системи доказів Гетьманської держави належали грамоти, оглядини, речові докази, допити на муках. Важливе місце посідало подання письмових грамот, які поділялися на публічні та приватні. Публічні грамоти, до яких належали будь-які урядові документи, та документи, складені перед урядом і поміщені в урядові книги, деякі договори, вважалися повним доказом, тому проти них суд не допускав доказів від свідків чи присяги. Меншу вартість мали приватні документи, які можна було заперечувати іншими доказами [3, с. 77].

Кримінальний процес у Гетьманщині будувався на підставах модернізаторства, оскільки цих принципів у сучасних формулюваннях тогочасне правознавство не знало. Йдеться про принципи законності (кримінальне судочинство повинно було керуватися законом або санкціонованими державою звичаями); здійснення правосуддя судами або іншими наділеними судовими функціями державними органами (виключалися самосуд або судові дії посадовців, не уповноважених на те); презумпції невинуватості (вину особи доводив тільки суд або прирівняний до нього орган); диспозитивності (провадження у кримінальній справі могло бути порушене лише за скаргою потерпілого); змагальності (проявлявся безпосередньо під час судового розгляду); забезпечення права обвинувачуваного на захист (міг вдаватися до послуг як професійного адвоката, так й іншої довіреної особи); відкритості судового процесу в кримінальних справах (могли бути присутніми всі правоздатні особи); усності судочинства (сторони з'являлися в суд особисто й усно доводили власну правоту); безпосередності (суди першої інстанції повинні були перевірити всі факти i докази по справі); формалізму (почав проявлятися на початку XVIII ст., полягав у тому, що всі кримінальнопроцесуальні дії повинні були здійснюватися за встановленою формою) $[4$, c. 84$]$.

На території Гетьманщини діяв Кодекс українського права «Права, за якими судиться малоросійський народ», 1743 р., який містив значну кількість найважливіших норм процесуального права. Хоча Сенат так і не був затверджений, він мав значне поширення в Україні. Судоустрою були присвячені розділи 7, 8, 9, норми винятково кримінально-процесуального права містилися у розділі 25, у якому, зокрема, йдеться про ведення допиту злочинців та запідозрюваних у злочинах «під муками», ведення в судах спеціальних книг для «запису справ карних», порядок виконання вироків тощо. Цей законодавчий акт передбачав застосування як змагальнообвинувального, так й іноді слідчого (інквізиційного) процесів під час розгляду та вирішення кримінальних справ [5]. 
Четвертий імперський період 3 кінця XVIII ст. до початку XX ст. Україна перебувала у складі Російської імперії.

Треба зазначити, що в період 3 кінця XVIII ст. до початку XX ст. близько 90\% українських земель входили до складу Російської імперії. Потрібно врахувати ту обставину, що загалом розвиток кримінального процесу в Наддніпрянській Україні в науковому аспекті досліджений порівняно недостатньо.

Це стосується, зокрема, питань систематизації кримінальнопроцесуального законодавства, стадій попереднього розслідування, розвитку основних розшукових органів, а саме Особливої канцелярії МВC, Третього відділення, корпусу жандармів, тому слід зіставити їх фактичну діяльність до норм чинного кримінально-процесуального законодавства, показати ступінь особистої участі монархів у судочинстві з особливо важливих політичних злочинів, виявити тенденції розвитку кримінального процесу та врахувати досвід того часу.

На початку XIX ст. в Росії вже відбувалися спроби вдосконалення кримінально-процесуального

судочинства. Ці спроби здійснювалися за певними напрямами. По-перше, законодавець прагнув узгодити закони та звести вже наявні акти в певну систему, підготувавши новий зведений нормативно-правовий акт; по-друге, для вдосконалення національного законодавства стала використовуватися рецепція іноземного права як шляхом запозичення цілих нормативних актів, так i шляхом їх перероблення та узгодження 3 вітчизняними актами; по-трете, замість застарілого Соборного Уложення необхідно було розробити новий загальний кодифікований акт 3 урахуванням модних тоді європейських віянь на основі природного права.

Спроби

вдосконалення

кримінального судочинства були пов'язані 3 діяльністю Комісій для складання законів та складання законів щодо впорядкування кримінальнопроцесуального законодавства. Загалом результати роботи Комісії для складання законів оцінювалися вкрай незадовільно. Так, 25 серпня 1801 р. був виданий наказ Комісії щодо складання законів судоустрою та судочинства, яким надавалась виняткова важливість для затвердження спокою в державі. За дорученням імператора М. Сперанський визначив основу наведення порядку в судочинстві в законодавства.

Саме розробленням проєкту Статуту кримінального судочинства керував Г. Розенкампф. Проєкт внесли на розгляд Державної ради, однак його не прийняли. Проте накопичений досвід був широко використаний під час створення Повного зібрання та Зводу законів Російської імперії. Деякі положення судових проєктів лягли в основу Статуту кримінального судочинства 1864 p. Недоліки проєктів дали змогу M. Сперанському переглянути свої погляди на проведення систематизації, критично осмислити свою законотворчість, а на основі всієї діяльності Комісії розробити новий план і методику систематизації кримінальнопроцесуального законодавства [6, с. 143].

В основу Зводу законів, перше видання якого з'явилося при Миколі I у 1832 р., склавши другу книгу XV тому, лягли основні положення законодавчих актів за часів Петра I, Катерини II та їх наступників. Порядок кримінального судочинства за Зводом законів 1832 р. був побудований за принципом німецького дореформеного процесу. Так, у Зводі блок кримінально-процесуальних норм був сконсолідований та отримав назву «Про судочинство за злочинами», але цей блок норм став лише складовою частиною Зводу. Однак Звід деяким чином удосконалив судовий процес, але зберіг його клановість та елементи формальної системи доказів (досконалі та недосконалі докази) [7]. 
Процес став поділятися на стадії (попереднє розслідування, суд та вирок), що дало змогу досить чітко розподілити функції учасників процесу на кожній 3 них. Попереднє розслідування й вирок належали до відома поліції. В її ж віданні перебував суд за злочинами невеликої тяжкості. Суд у нижчих інстанціях (повітовий суд, палати кримінального суду) складався 3 посадових осіб, призначених урядом, i виборних засідателів від станів. У судах вищих, наприклад сенаті, допускалися тільки призначені посадові особи.

В рамках систематизації законодавства попереднє розслідування поділялося на попереднє слідство та формальне слідство. Попереднє слідство передбачало дознавальні дії за законом та за наявності певних підстав (повідомлення або донос про відомі донощику ознаки злочину, за який на нього не покладались обов'язки щось доводити; скарги потерпілого; документи прокурорів та стряпчих; явки з повинною та, нарешті, зі власного розсуду поліції, яка приступала до слідства на основі отриманих нею відомостей).

До попереднього слідства належали встановлення факту злочину, для чого могли бути проведені різні допити, а також особисті огляди, експертиза, обшуки та виїмки, виклик або привід підозрюваного, його допит i вжиття запобіжних заходів, серед яких головним було особисте затримання. Кримінально-процесуальний закон регулював практично всі відомі в той час слідчі дії, при цьому найбільша увага приділялася все ж таки допиту спочатку в поліції, а потім під час проведення формального слідства, оскільки саме свідчення підозрюваних та звинувачених становили основне джерело доказів.

Формальне слідство з'ясовувало те, над якою особою чи майном був скоєний злочин, якими засобами, коли, де, навмисно або ненавмисно. Під час проведення формального слідства була необхідна присутність представників від того стану, до якого належав обвинувачений. Прокурори та стряпчі мали спостерігати за ходом слідства, а особливо за тим, щоб обвинувачені могли скористатися всіма наданими законом засобами до захисту. Формальне слідство полягало в зборах та записі всіх доказів.

Після закінчення слідства всі матеріали негайно відсилалися в суд, який розглядав те, чи правильно проведено слідство, опитував обвинуваченого, 3'ясовував, чи не було йому спричинено незаконних допитів, за потреби піддавав його знову допитам, намагаючись схилити до визнання провини. 3 доказами суд знайомився виключно в письмовому варіанті, яке надавало слідство, і в канцелярії суду складався спеціальний витяг. Суд міг надати розпорядження щодо додаткового слідства, але сам проводити огляди або допити свідків не мав права. Рішення суду грунтувалось на встановлених в законі правилах щодо сили доказів. Однак під час розслідування злочинів проти держави робилися винятки iз загальних кримінально-процесуальних норм, що свідчило про те, що державна влада робила все, щоб не допустити жодних намірів на наявний лад [8, с. 118].

Вирок повинен був виноситися на основі достатніх доказів винності та відповідності закону. Встановлювалося, що за нестачі доказів слід було звільнити підсудного, проте один досконалий доказ міг послужити підставою до винесення вироку. Формальна сила доказів була видозмінена порівняно 3 попереднім часом шляхом введення поняття «віддавати перевагу», але станові й інші відмінності учасників процесу, як і раніше, впливали на силу їх показань. Щодо справ за злочинами проти держави переважно застосовувався загальний підхід, однак під час розслідування та судового розгляду особливо важливих політичних справ владою встановлювалися спеціальні правила. Кримінально-процесуальні та кримінально-виконавчі норми, пов'язані 3 процедурою винесення вироку та його реалізації, концентрувалися послідовно в 
таких законах, як Статут про засланців 1822 p. та Звід законів кримінальних 1832 р.

Законодавець визначав судове рішення на підставі достатніх доказів i строго за законом. Вирок мав бути оголошений підсудному, який міг його оскаржити або подати прохання про помилування, при цьому була можливість апелювання до імператора, який за законом визначався як «верховний суддя», відповідно, до нього направлялися рішення судів про засудження за політичні злочини для затвердження. Здебільшого засуджені за державні злочини засуджувалися до покарань, пов'язаних 3 позбавленням волі. Умови відбування покарання в місцях ув'язнення також детально регламентувалися законом, проте на практиці дуже часто норми не виконувались, а стан в тюрмах навіть в офіційних повідомленнях оцінювався як вкрай незадовільний.

15 серпня 1845 р. була успішно завершена дев'ятирічна кропітка робота «Уложення про покарання кримінальні та виправні», яка підписана імператором Миколою I. Це перший кодифікований акт у сфері російського кримінального права, що діяв також в українських губерніях Російської імперії в другій половині XIX ст. - на початку XX ст. [9].

Вперше для карного законодавства Російської імперії було проведено поділ на загальну та спеціальну частини. В документі йшлося про формальне визначення поняття злочину, а саме діяння, заборонене законом під страхом покарання. Також були зазначені менш тяжкі протиправні дії. Проступок визначався як порушення правил, призначених для охорони визначених законами прав громадської або особистої безпеки й користі. За ступенем тяжкості злочини було поділено на тяжкі, звичайні та проступки.

Загальновідомим $є$ факт, що особлива частина кримінального закону будується за ступенем важливості охоронюваної сфери суспільних відносин. Особлива частина Уложення розпочиналася злочинами проти віри, крім того, були виділені розділи й глави, де окремо узагальнювались склади злочинів власне проти політичної влади (бунти, повстання тощо), проти порядку управління, посадові злочини тощо. За своїм змістом диспозиції державних злочинів були спрямовані на захист наявного ладу (абсолютної монархіі), при цьому передбачалися досить жорсткі покарання, зокрема бунт проти влади карався стратою й посиланням на каторгу [9].

Судочинство у всіх його стадіях було негласним, тільки вирок суду підлягав оголошенню, щоби перш за все підтримати систему залякування. Вироки судів першої інстанції переглядалися в ревізійному порядку. Перегляд вироків за скаргами підсудних допускався тільки у справах менш тяжких, які не підлягали ревізії.

Згодом були допущені скарги підсудних 3 непривілейованих станів до сенату на вироки про тілесне покарання й заслання на поселення або в каторгу, але скарги могли надаватися тільки після виконання вироку. В разі необгрунтованості скарги засуджений піддавався тілесному покаранню, а якщо скарга виявлялася грунтовною, то сенат поновлював засудженого в його правах, водночас визначав йому винагороду за понесене покарання й накладав стягнення на осіб, які винесли несправедливий вирок.

Судочинство велося в письмовій формі, суд виносив рішення на підставі записаних у протокол показів свідків, звинувачуваних, експертів та інших письмових документів. На основі письмових протоколів за суворо формальними правилами оцінювання доказів суд вирішував долю звинувачуваного. Процес залишався інквізиційним, під час судочинства застосовували тортури до звинувачуваних, щоби досягти визнання ними своєї провини (хоча 31801 p. тортури в кримінальному процесі заборонялися). Рішення нижчих судів 
обов'язково надсилали на затвердження вищим. В окремих справах (переважно щодо дворян) вирок суду після розгляду справи в декількох судових інстанціях доповідався цареві, від якого залежало кінцеве рішення.

Отже, судовий процес Гетьманщини в XVIII ст. загалом зберіг основні ознаки попереднього періоду. Однак посилене втручання Росії у внутрішні справи України, зокрема іï судочинство, внесло певні зміни. Український змагальний процес із його простотою, демократичністю та доступністю поступово витісняється інквізиційним процесом. Водночас слід відзначити позитивні зміни в судочинстві Гетьманщини. Так, законодавством передбачено низку випадків, коли кримінальна справа порушується судовими органами без скарги потерпілого. Таким чином, кримінальний процес Гетьманщини набуває публічного характеру.

Однак в судах Російської імперії та російської України у XIX ст. судочинство було таємним, громадськість не допускалась на засідання суду. Крім того, правове регулювання виробництва основних слідчих дій в імперський період зазнало зміни перш за все за формою закріплення відповідних кримінальнопроцесуальних норм до 1832 р., які розташовувалися в безлічі різних правових актів, а 31832 р. вони були згруповані в Книзі другій Зводу законів кримінальних, але загалом зі змінами більш демократичного характеру, про що свідчить перш за все наявність норм, які гарантують певні процесуальні права підозрюваних та обвинувачених, вимоги гуманного до них ставлення, зокрема прямо заборонялося використовувати фізичний вплив, а також більш детальне регулювання інституту захисту підозрюваних та обвинувачених (інститут «депутатів»).

У другій половині XIX ст. утворився тип процесу, який відповідав рівню передових європейських держав, що визнавали багато науковців. I. Фойницький констатував, що в нашому новому процесі $\epsilon$ багато спільного 3 англійським, особливо французьким процесом; загалом він наближається до того ж типу, котрий вироблений цими кращими представниками європейської культури, та встановлює наші родинні зв'язки. Варто підкреслити, що, оцінюючи тип процесу як демократичний та прогресивний, учений мав на увазі його досудову частину, а саме досудове слідство. Висловлюючи загальну думку вченихпроцесуалістів, вчений зазначав, що судові статути 1864 р. в історії російського життя знаменують поворот від порядку поліцейського до порядку правового, що було живим свідченням боротьби старої та нової систем [10, с. 424].

\section{Література}

1. Руська Правда. URL: http:// litopys.org.ua/oldukr2/oldukr51.htm.

2. Литовський Статут. URL: http: //litopys.org.ua/statut2/st1566.htm.

3. Падох Я. Суди і судовий процес Старої України. Нью-Йорк - Париж -Сідней Торонто. Львів : Наукове товариство ім. Шевченка, 1990. 128 с.

4. Стецюк Б. Органи кримінального судочинства Гетьманщини. Підприємництво, господарство і право. 2005. № 11. С. 82-85.

5. Права, за якими судиться малоросійський народ, 1743 p. URL: http://archeos.org.ua/wp-content/uploads/2013/12/.pdf.

6. Власов Г., Гончаров Н. История розыскного процесса в России (законодательство и практика) : монография. Домодедово : РИПК МВД России, 1997. 234 с. 
7. Свод законов Российской империи, повелением государя императора Николая Павловича составленный. Изд. 1832 г. Т. 15. Санкт-Петербург, 1832. URL: http://www.prlib.ru/Lib/Pages/authority_1-2-4-2.

8. Ефремова Н. Судоустройство России в XVII - первой половине XIX вв.: историкоправовое исследование : монография. Москва: Наука, 1993. 192 с.

9. Уложение о наказаниях уголовных и исправительных 1845 года. Полное собрание законов Российской империи. Санкт-Петербург, 1846. T. XX. Отделение I. URL: http://nlr.ru/e-res/law_r/search.php?part=510\&regim=3.

10. Фойницкий И. Курс уголовного судопроизводства / под ред. А. Смирнова. СанктПетербург : Альфа, 1996. 607 с.

\section{References}

1. "Ruska Pravda", available at: http:// litopys.org.ua/oldukr2/oldukr51.htm.

2. "Lithuanian Statute", available at: http: //litopys.org.ua/statut2/st1566.htm.

3. Padokh, Ya. (1990), Sudy i sudovyi protses Staroi Ukrainy [Courts and litigation of Old Ukraine], New York - Paris - Sydney - Toronto, Naukove tovarystvo im. Shevchenka, Lviv, Ukraine.

4. Stetsiuk, B. (2005), "Bodies of criminal proceedings of the Hetmanate", Pidpryiemnytstvo, hospodarstvo i pravo, no. 11, pp. 82-85.

5. (1743), "Rights under which the Little Russian people are sued", available at: http://archeos.org.ua/wp-content/uploads/2013/12/.pdf.

6. Vlasov, G.. and Goncharov, N. (1997), Istoriya rozysknogo processa $v$ Rossii (zakonodatelstvo i praktika) : monografiya [The history of the search process in Russia (legislation and practice) : monograph], RIPK MVD Rossii, Domodedovo, Russia.

7. (1832), "The Code of Laws of the Russian Empire, by order of the Emperor Nikolai Pavlovich", Publishing House 1832, Vol. 15, Saint-Petersburg, available at: http: // www.prlib.ru/Lib/Pages/authority_1-2-4-2.

8. Efremova, N. (1993), Sudoustrojstvo Rossii v HVII - pervoj polovine XIX vv.: istorikopravovoe issledovanie : monografiya [The judicial system of Russia in the XVII first half of the XIX centuries .: historical and legal research : monograph], Nauka, Moscow, Russia.

9. (1846), "Code of Criminal and Correctional Sentences of 1845. Complete collection of laws of the Russian Empire", Saint-Petersburg, Vol. XX. Department I, available at: http://nlr.ru/e-res/law_r/search.php?part=510\&regim=3.

10. Fojnickij, I. (1996), Kurs uholovnoho sudoproizvodstva [Criminal Justice Course], Alfa, Saint-Petersburg, Russia. 


\section{РОЗДІЛ ІІ. ЗЕМЕЛЬНЕ ПРАВО; АГРАРНЕ ПРАВО; ЕКОЛОГІЧНЕ ПРАВО; ПРИРОДОРЕСУРСНЕ ПРАВО}

УДК 349.42:636.08

DOI https://doi.org/10.26661/2616-9444-2019-2-02

\section{Сучасний стан правового регулювання органічного тваринництва в Україні: актуальні проблеми}

Бондар О. Г., Луц Д. М.

Запорізький національний університет, вул. Жуковського, 66, м. Запоріжжя, Україна bondar.znu@gmail.com,dimaluts89@gmail.com

\begin{abstract}
Ключові слова: органічне органічне продукиія тваринного походження, племінна справа, державна підтримка, регіональна програма розвитку.
\end{abstract}

Надійшло до редколегї: 05.09.2019

Прийнято до друку: 18.10 .2019
У статті досліджено актуальні проблеми формування інституту правового регулювання органічного тваринництва. Встановлено, що наявна нормативно-правова база, яка регулює відносини у зазначеній сфері, потребує вдосконалення, насамперед, у контексті євроінтеграційних процесів. На підставі аналізу законодавчого визначення поняття «органічне тваринництво» запропоновано доповнити його прив'язкою до селекційної роботи. Зроблено висновок про необхідність узгодження нормативних положень, 3 одного боку, у сфері племінної справи у тваринництві, а 3 іншого боку, щодо органічного тваринництва. Окреслено проблеми щодо нормативного забезпечення державної підтримки, зокрема фінансової, галузі органічного тваринництва, а також сформульовано певні пропозиції щодо їх вирішення. Досліджено зміст окремих регіональних програм підтримки аграрного сектору економіки, визначено їх роль та потенціал в організаційноправовому механізмі підтримки органічного тваринництва на відповідних територіях.

\section{The current state of legal regulation of organic animal breeding in Ukraine: actual problems}

Bondar O. G., Luts D. M.

Zaporizhzhya national university, str. Zhukovsky, 66, Zaporizhzhya, Ukraine

bondar.znu@gmail.com,dimaluts89@gmail.com

Key words:

organic production, organic livestock breeding, legal regulation of organic livestock breeding, products of the animal origin, pedigree business, state support, regional development program.
Actual problems of formation of institute of legal regulation of organic livestock breeding are investigated. It is established that the existing legal framework regulating relations in this area needs improvement, especially in the context of European integration processes.

It is concluded that today there is a question of ensuring consumption of not only quality and safe products, but also organic products of animal origin. 
One of the vectors determined by the Ukraine 2020 Sustainable Development Strategy is the safety vector, which, among other things, emphasizes the need to ensure a safe environment and access to quality drinking water, safe food and manufactured goods. It is determined that the implementation of this vector should cover the area of production and circulation of organic agricultural products, a significant part of which is products of animal origin.

Based on the analysis of the definition of "organic livestock breeding", enshrined in the Law of Ukraine "On basic principles and requirements for organic production, circulation and labeling of organic products", it is concluded that it is quite blurred, as it includes the categories "products needed for breeding animals" and "obtained products of animal origin". There seems to be a gap in the proposed definition, which is not mentioning of the breeding work that is necessary for bringing in new breeds of animals that are more suitable for organic livestock. On this basis, the following definition is proposed: "Organic livestock is an organic production related to the keeping, raising and breeding of farm animals (including poultry and insects) that meet the statutory requirements aimed at obtaining organic production".

In order to improve the legal regulation of organic livestock breeding, it is proposed to complete Art. 6 of the Law of Ukraine "On pedigree business in livestock breeding" with a separate item that would stipulate the need to raise pedigree animals for further use in the field of organic livestock breeding. In order to establish breeding work that will be aimed at raising of new breeds that will be suitable for organic animal husbandry, there is a need to harmonize the provisions of legislative and regulatory normative acts, on the one hand, in the field of livestock breeding business, on the other - in the field of organic animal breeding.

The problems of normative foundation of state assistance, financial in particular, sphere of organic livestock breeding are outlined and some proposals for their solution are formulated.

The content of individual regional programs to support the agricultural sector of the economy is investigated and their role and potential in the organizational and legal mechanism of support of organic livestock breeding in the respective territories is determined.

Як засвідчує досвід провідних зарубіжних країн, щороку відбувається стабільний приріст у постачанні на світові ринки органічної сільськогосподарської продукції. Якщо у 1999 р. такої продукції було реалізовано на 15,2 млрд. доларів США, то у 2017 р. - на 97 млрд. [1]. Розвиток органічного виробництва $\epsilon$ вельми актуальним сьогодні з огляду на низку очевидних екологічних, економічних та соціальних переваг, що притаманні цій сфері діяльності. Серед завдань, поставлених Концепцією Державної цільової програми розвитку аграрного сектору економіки на період до 2020 р., передбачається, окрім іншого, сприяння створенню нових потужностей iз виробництва й глибокої переробки сільськогосподарської продукції та модернізації наявних, зокрема, у сфері виробництва органічної продукції, розширення площі виробництва 
органічної продукції та сировини, що свідчить про наміри покращити наявну ситуацію у сфері виробництва органічної сільськогосподарської продукції [2].

Повністю

вищевикладене стосується галузі органічного тваринництва. Протягом останніх років в Україні окреслилась позитивна динаміка в цій сфері, проте наявна нормативноправова база потребує вдосконалення, насамперед у контексті євроінтеграційних процесів.

Метою статті $\epsilon$ дослідження сучасного стану правового регулювання органічного тваринництва в Україні та формулювання на цій основі рекомендацій щодо вдосконалення нормативного забезпечення розвитку вказаної галузі.

У вітчизняній правовій науці спостерігається певний брак праць, які би приділяли увагу досліджуваній тематиці, водночас наявні суттєві напрацювання таких учених, як А.П. Гетьман, В.Ю. Уркевич, М.В. Шульга, В.В. Носік, В.М. Срмоленко, А.С. Овчаренко, Т.К. Оверковська, Т.М. Магомедова. На окрему увагу заслуговує стаття T.В. Курман «Проблеми законодавчого забезпечення виробництва органічної продукції тваринництва», а також монографія «Органічне сільське господарство: еколого-економічні імперативи розвитку» (Київ, 2015 р.).

Відповідно до ст. 50 Конституції України кожному гарантується право вільного доступу до інформації про стан довкілля, якість харчових продуктів i предметів побуту, а також право на їі поширення. Така інформація ніким не може бути засекречена [3]. Частина 3 ст. 42 Основного Закону покладає на державу обов'язок захищати права споживачів, здійснювати контроль за якістю й безпечністю продукції та всіх видів послуг і робіт [3].

Вимоги щодо безпечності харчових продуктів закладені у Законі України від 23 грудня 1997 р. (в редакції від 22 липня 2014 р.) «Про основні принципи та вимоги до безпечності та якості харчових продуктів», який регулює відносини між органами виконавчої влади, операторами ринку харчових продуктів та споживачами харчових продуктів, а також визначає порядок забезпечення безпечності та окремих показників якості харчових продуктів, що виробляються, перебувають в обігу, ввозяться (пересилаються) на митну територію України та/або вивозяться (пересилаються) 3 неї [4].

Відповідно до ст. 1 цього Закону безпечний харчовий продукт - це харчовий продукт, який не справляє шкідливого впливу на здоров'я людини та $\epsilon$ придатним до споживання [4]. Одним із видів харчової продукції $\epsilon$ продукція тваринного походження, до якої цією ж статтею віднесено молоко, м'ясо, рибу, молюсків та ракоподібних, зокрема свіжих, охолоджених або заморожених, яйця, мед, їх похідні та інші продукти, виготовлені $з$ частин тварин, окремих їх органів та/або тканин, призначені для споживання людиною [4].

Проте в реаліях сьогодення постає питання про споживання не просто якісної продукції, а органічної продукції тваринного походження. Як слушно зазначає А.С. Овчаренко, «із трансформацією споживчих уподобань, активним використанням альтернативних методів сільського господарства, екологізацією міжнародної торгівлі тощо виникає необхідність підтримки розвитку органічного фермерства» [5, с. 42]. Аналізуючи правові ознаки органічного виробництва сільськогосподарської продукції в Україні, Т.К. Оверковська наголошує на тому, що, згідно з різними експертними оцінками, найближчим часом частка екологічно чистої продукції у світовому продовольчому балансі сягне 14-30\%. До 2020 р., як пише вчена, екологічні продукти харчування займуть четверту частину світового екологічного ринку [6, с. 94].

Говорячи про відповідні перспективи в нашій державі, акцентуємо 
увагу на тому, що одним із векторів руху, передбачених Стратегією сталого розвитку «Україна - 2020», схваленою Указом Президента України від 12 січня 2015 p. № 5/2015, є вектор безпеки, який, окрім іншого, акцентує увагу на необхідності забезпечення безпечного стану довкілля й доступу до якісної питної води, безпечних харчових продуктів та промислових товарів [7]. Цілком логічно, що реалізація цього вектору має охоплювати сферу виробництва та обігу органічної сільськогосподарської продукції, значну частку якої складає продукція тваринного походження.

Варто зазначити, що довгий час у вітчизняному законодавстві була відсутня дефініція «органічне тваринництво». Ця прогалина була усунута 3 прийняттям Закону України «Про основні принципи та вимоги до органічного виробництва, обігу та маркування органічної продукції» від 10 липня 2018 р., який вступив в дію 2 серпня поточного року (далі - Закон про органічне виробництво). У ньому визначено, що органічне тваринництво це органічне виробництво, пов'язане 3 утриманням, розведенням (виробництвом) сільськогосподарських тварин (зокрема, птиці та комах) та продукції для отримання продукції тваринного походження [8]. Законом України «Про захист тварин від жорстокого поводження» від 21 лютого 2006 р. [9] встановлено, що до сільськогосподарських слід відносити тварин, що утримуються та розводяться людиною для отримання продуктів i сировини тваринного походження. Ми поділяємо точку зору Д.Є. Захарова про те, що сільськогосподарських тварин можна виділити як різновид домашніх тварин, що утримуються та розводяться людиною задля задоволення різноманітних потреб, зокрема харчування, виготовлення одягу, медичних препаратів, використання як тяглової сили, транспортних засобів [10, c. 17].
Також Закон про органічне виробництво встановлює, що органічні тварини - це тварини (зокрема, птиця та комахи), вирощені в результаті органічного тваринництва.

Аналіз визначення «органічне тваринництво», на нашу думку, дає підстави констатувати, що воно є досить розмитим, оскільки включає категорії «продукція, необхідна для вирощування тварин» та «отримана продукція тваринного походження». Окрім цього, вбачається, що прогалиною запропонованої дефініції $є$ відсутність згадки про селекційну роботу, необхідну для виведення нових порід тварин, які будуть придатними для органічного тваринництва та, зрештою, даватимуть кращу та більш безпечну продукцію.

3 урахуванням наведеного пропонуємо таке визначення: органічне тваринництво - це органічне виробництво, пов'язане 3 утриманням, розведенням та виведенням порід сільськогосподарських тварин (зокрема, птиці та комах), які відповідають встановленим вимогам, задля отримання органічної продукції.

Стаття 19 Закону про органічне виробництво унормовує вимоги для органічного тваринництва шляхом їх поділу на відповідні групи, які включають вимоги щодо походження тварин, методів утримання, розведення, годування, профілактики хворіб та ветеринарного лікування, прибирання та дезінфекції. Аналізуючи цю статтю, Т.В. Курман зосереджує увагу на відсутності такої важливої групи вимог для органічного тваринництва, як вимоги щодо пасовищ. Це, на iï думку, є прогалиною Закону, адже «від якісного стану пасовищ, зон їх розміщення, наявності доступу до водних джерел, їх стану та інших чинників залежить те, чи можна отриману продукцію тваринництва вважати органічною» [11, с. 155]. Поділяючи цю точку зору, вважаємо, що ці вимоги мають бути включені до п. 4 ст. 19 вказаного Закону, що встановлює вимоги щодо 
годування тварин, але шляхом використання поняття «земельні ділянки для вирощування кормів для худоби», про що йдеться, зокрема, у працях Т.М. Магомедової [12, с. 131].

Як вже зазначалося вище, значну роль під час ведення органічного тваринництва має відігравати селекційна робота, що має спрямовуватися на виведення нових порід, які максимально відповідатимуть встановленим вимогам задля отримання органічної продукції. Вимоги щодо розведення органічних тварин встановлені у ч. 3 ст. 19 Закону про органічне виробництво, а саме репродукція тварин має відбуватися природним шляхом, проте дозволяється штучне запліднення; забороняється застосування гормонів під час репродукції; забороняється застосування клонування та трансплантація ембріону; відбувається вибір відповідних порід, адаптованих до умов місцевості вирощування тварин, життєздатних та стійких до хворіб для попередження страждань тварин та необхідності хірургічного втручання [8].

Наведені законодавчі положення встановлюють загальні підвалини, які розвиваються у Детальних правилах виробництва органічної продукції (сировини) тваринного походження, затверджених Постановою Кабінету Міністрів України від 30 березня 2016 р. № 241 [12]. $У$ цьому нормативному документі закріплено, що під час вибору порід тварин для виробництва органічної продукції (сировини) тваринного походження перевага віддається місцевим породам, враховується їх стійкість до специфічних хворіб або проблем зі здоров'ям, а саме синдрому стресу свиней, синдрому PSE, раптової смерті, мимовільного аборту і складних пологів, які потребують кесаревого розтину [13].

Вбачається, що у сфері органічного тваринництва пріоритет має віддаватися племінним тваринам, під якими, відповідно до Закону України «Про племінну справу у тваринництві» від 15 грудня 1993 р. (в редакції від 21 грудня 1999 р.), розуміються чистопородні або одержані за затвердженою програмою породного вдосконалення тварини, що зареєстровані в державних книгах племінних тварин, мають племінну (генетичну) цінність i можуть використовуватися в селекційному процесі відповідно до програм селекції [14]. Задля вдосконалення правового регулювання органічного тваринництва, на нашу думку, необхідно доповнити ст. 6 вказаного Закону, де зафіксовані завдання племінної справи у тваринництві, пунктом, який би закріплював необхідність вирощування племінних тварин для подальшого використання в галузі органічного тваринництва.

Очевидно, що держава має вживати заходів щодо підтримки розвитку органічного тваринництва. Як слушно йдеться в монографії «Актуальні проблеми правового забезпечення продовольчої безпеки України» (Харків, 2013 р.), до організаційно-правової функції Міністерства аграрної політики та продовольства України, окрім іншого, належить «запровадження системи ведення органічного сільського господарства, організації впровадження екологічно безпечних для людини i довкілля методів та заходів щодо захисту рослин» [15, с. 76-77]. Х.А. Григор'єва розглядає розвиток органічного сільськогосподарського виробництва як один із невід'ємних елементів правового забезпечення державної підтримки екологізації сільськогосподарської діяльності [16, с. 466]. Ці тези, окрім іншого, є одним із цілої низки аргументів щодо позиції про недоцільність рішення стосовно ліквідації Мінагрополітики й передачі його функцій та повноважень до Міністерства розвитку економіки, торгівлі та сільського господарства України.

Отже, загальні засади такого протекціонізму закладені у ст. 8 Закону про органічне виробництво, відповідно до якої «державна підтримка може надаватися операторам у рамках 
загальнодержавних та регіональних програм за рахунок і в межах видатків за бюджетними програмами, спрямованими на підтримку розвитку сільськогосподарських товаровиробників» [8]. Проте слід звернути увагу на той факт, що підтримка 3 державного бюджету може виділятися лише на ті заходи, вжиття яких передбачено Кабінетом Міністрів України. Зокрема, Постановою Кабінету Міністрів України «Про затвердження Порядку використання коштів, передбачених у державному бюджеті для підтримки тваринництва, зберігання та переробки сільськогосподарської продукції, аквакультури (рибництва)» від 7 лютого 2018 р. № 107 встановлено вичерпний перелік напрямів, за якими можуть спрямовуватися бюджетні кошти [17]. 27 березня поточного року Уряд України видав Розпорядження «Про розподіл коштів, передбачених у державному бюджеті за програмою 2801540 «Державна підтримка тваринництва, зберігання та переробки сільськогосподарської продукції, аквакультури (рибництва)» на 2019 р.» № 196-p [18]. Одним із напрямів використання коштів, згідно 3 цим документом, $\epsilon$ часткове відшкодування вартості закуплених для подальшого відтворення племінних тварин, а саме телиць, нетелей, корів молочного, молочно-м'ясного та м'ясного напрямів продуктивності, свинок та кнурців, вівцематок, баранів, ярок і сперми бугаїв, ембріонів великої рогатої худоби, які мають племінну (генетичну) цінність. Водночас згадки про органічне тваринництво немає. Однак органічне тваринництво не може розвиватися без відтворення племінних тварин, тому вважаємо, що задля стимулювання розвитку відповідної галузі необхідно додати до Постанови Кабінету Міністрів України від 7 лютого 2018 р. № 107 комплекс заходів 3 підтримки органічного тваринництва. \begin{tabular}{ccr}
\multicolumn{1}{c}{ Задля } & всебічного & розгляду \\
порушеної & проблематики & потребує \\
дослідження & наявність & відповідних
\end{tabular} регіональних програм. Одразу варто окреслити, що регіональні програми доцільно поділити на дві групи, а саме загального та галузевого спрямування.

До програм загального

спрямування варто віднести комплексні програми агропромислового розвитку відповідних територій. Вивчивши такі програми, ми дійшли висновку про відсутність у їх більшості положень про галузь органічного тваринництва. Проте в деяких програмах йдеться про необхідність розвитку напряму виробництва органічної сільськогосподарської продукції. До таких належить, наприклад, Комплексна програма розвитку агропромислового комплексу Волинської області на 20162021 pp. [19]. Деякі програми передбачають необхідність розроблення заходів щодо мотивації у сільськогосподарських товаровиробників до розвитку трудомістких галузей, зокрема овочівництва, хмелярства, льонарства, тваринництва, органічного виробництва (Програма розвитку агропромислового комплексу Житомирської області на 2016-2020 pр. [20], Комплексна програма розвитку агропромислового комплексу та сільських територій Івано-Франківської області на 2016-2020 pp. [21]).

До галузевих регіональних програм варто віднести ті, в яких йдеться про окремо взяті галузі. Згідно 3 наявною інформацією Міністерства аграрної політики та продовольства України нині діють такі Регіональні програми щодо підтримки галузі тваринництва, як Програма розвитку та підтримки тваринництва, птахівництва i бджільництва у Закарпатській області на 2016-2020 pр., Регіональна програма розвитку галузі вівчарства в сільськогосподарських підприємствах Запорізької області на 2015-2019 рр., Програма розвитку галузі молочного 
скотарства у Черкаській області на 20102020 pр., Програма розвитку галузі свинарства у Черкаській області на 20102020 pp. [22].

Показовою $є$ Програма фінансової підтримки органічного виробництва в Чернігівській області на 2015-2020 pp., затверджена Рішенням Чернігівської обласної ради від 29 квітня 2015 р. Ця програма спрямована на вирішення таких завдань, як охорона здоров'я тварин шляхом заохочення природного імунного захисту тварин, відбору відповідних порід; врахування під час вибору порід ступеня адаптації тварин до місцевих умов, їх життєздатності та стійкості до хворіб; виробництво продукції органічного тваринництва 3 тварин, що були вирощені в органічних господарствах від самого народження впродовж усього життя; годування тварин органічними кормами; виключення використання штучно виведених поліплоїдних тварин [23].

Підсумовуючи, можемо зробити висновок, що в наявних нормативноправових актах щодо органічного виробництва наявні суттєві лакуни щодо спеціального регулювання відносин у сфері органічного тваринництва. Суттєвим кроком уперед стало законодавче визначення поняття «органічне тваринництво», яке, однак, потребує коригування. Безперечним $\epsilon$ факт необхідності проведення селекційної роботи, яка буде спрямовуватися на виведення нових порід, які будуть придатними для органічного тваринництва. У цьому контексті слід налагодити на конструктивному зв'язку між Законом України «Про племінну справу у тваринництві» та підзаконними нормативно-правовими актами, що стосуються органічного тваринництва. Значна прогалина існує також у площині державної підтримки сфери органічного тваринництва. Наявні напрями можливого використання коштів із державного бюджету не дають можливості спрямовувати гроші на підтримку органічного тваринництва. Аналогічна проблема існує щодо прийняття відповідних програм на регіональному рівні.

\section{Література}

1. Світова органічна статистика 2019. URL : http ://organicinfo.ua/statystyka_2018.html (дата звернення : 07.10.2019).

2. Про схвалення Концепції Державної цільової програми розвитку аграрного сектору економіки на період до 2020 р. : Розпорядження Кабінету Міністрів України від 30 грудня 2015 р. № 1437-p. URL : https ://www.kmu.gov.ua/ua/npas/248907971 (дата звернення : 07.10.2019).

3. Конституція України : Закон України від 28 червня 1996 р. № 254к/96-BP. URL : https ://zakon.rada.gov.ua/laws/show/254к/96-вр (дата звернення : 07.10.2019).

4. Про основні принципи та вимоги до безпечності та якості харчових продуктів : Закон України від 23 грудня 1997 p. № 771/97-BP. URL : https ://zakon.rada.gov.ua/laws/show/771/97-вр (дата звернення : 07.10.2019).

5. Овчаренко А. С. Міжнародні та регіональні програми підтримки та популяризації органічного виробництва. Науковий вісник Міжнародного гуманітарного університету. Серія : Економіка. 2017. Вип. 28. С. 42-46.

6. Оверковська Т. К. Правові ознаки органічного виробництва сільськогосподарської продукції в Україні. Підприємництво, господарство і право. 2017. № 11. С. 94-98.

7. Про Стратегію сталого розвитку «Україна - 2020»: Указ Президента України від 12 січня 2015 р. № 5/2015. URL : https ://zakon1.rada.gov.ua/laws/show/5/2015 (дата звернення : 07.10.2019). 
8. Про основні принципи та вимоги до органічного виробництва, обігу та маркування органічної продукції : Закон України від 10 липня 2018 р. № 2496-VIII. URL : https ://zakon5.rada.gov.ua/laws/show/2496-viii (дата звернення : 07.10.2019).

9. Про захист тварин від жорстокого поводження : Закон України від 21 лютого 2006 p. № 3447-IV. Відомості Верховної Ради України. 2006. № 27. Ст. 230.

10. Захаров Д. Е. Животные как объекты гражданских прав : дисс. ... канд. юрид. наук : спец. 12.00.03. Екатеринбург, 2010. 207 с.

11. Курман Т. В. Проблеми законодавчого забезпечення виробництва органічної продукції тваринництва. Підприємництво, господарство і право. 2018. № 12. С. 153-157.

12. Воробйова (Магомедова) Т. М. Поняття земельних ділянок для вирощування кормів для худоби та їхнє місце в складі земель України. Право і суспільство. 2018. № 5. Ч. 1. С. $126-131$.

13. Про затвердження Детальних правил виробництва органічної продукції (сировини) тваринного походження : Постанова Кабінету Міністрів України від 30 березня 2016 p. № 241. URL : https ://zakon.rada.gov.ua/laws/show/241-2016-п (дата звернення : 07.10.2019).

14. Про племінну справу у тваринництві : Закон України від 15 грудня 1993 р. № 3691XII. URL : https ://zakon.rada.gov.ua/laws/show/3691-12 (дата звернення : 07.10.2019).

15. Актуальні проблеми правового забезпечення продовольчої безпеки України / за ред. В. Ю. Уркевича, М.В. Шульги. Харків, 2013. 326 с.

16. Григор'єва Х. А. Державна підтримка сільського господарства України : проблеми правового забезпечення : монографія. Херсон : Гельветика, 2019. 596 с.

17. Про затвердження Порядку використання коштів, передбачених у державному бюджеті для підтримки тваринництва, зберігання та переробки сільськогосподарської продукції, аквакультури (рибництва) : Постанова Кабінету Міністрів України від 7 лютого 2018 p. № 107. URL : https ://zakon.rada.gov.ua/laws/show/en/107-2018-п (дата звернення : 07.10.2019).

18. Про розподіл коштів, передбачених у державному бюджеті за програмою 2801540 «Державна підтримка тваринництва, зберігання та переробки сільськогосподарської продукції, аквакультури (рибництва)» на 2019 р. : Розпорядження Кабінету Міністрів України від 27 березня 2019 p. № 196-p. URL : https ://zakon.rada.gov.ua/laws/show/196-2019-p (дата звернення : 07.10.2019).

19. Про Комплексну програму розвитку агропромислового комплексу Волинської області на 2016-2021 рр. : Рішення Волинської обласної ради від 10 березня 2016 р. № 3/23. URL : http ://agrovolyn.gov.ua/article/kompleksna-programa-rozvytkuagropromyslovogo-kompleksu-volynskoyi-oblasti-na-2016-2021-roky (дата звернення : 07.10.2019).

20. Про Програму розвитку агропромислового комплексу Житомирської області на 2016-2020 pр. : Рішення Житомирської обласної ради від 7 березня 2018 р. № 938. URL : https ://zt.gov.ua/index.php/ofitsijni-dokumenti/normativni-dokumenti/rishennyaoblasnoji-radi/11638-№-938-про-програму-розвитку-агропромислового-комплексужитомирської-області-на-2016-2020-роки.html (дата звернення : 07.10.2019).

21. Про Комплексну програму розвитку агропромислового комплексу та сільських територій Івано-Франківської області на 2016-2020рр. : Рішення Івано-Франківської 
обласної ради від 16 жовтня 2015 p. № 1830-39/2015. URL : http ://www.if.gov.ua/files/uploads/КОМПЛЕКСНА\%20ПРОГРАМА_-фін.pdf (дата звернення : 07.10.2019).

22. Регіональні програми розвитку агропромислового комплексу / Міністерство аграрної політики та продовольства URL : https ://minagro.gov.ua/ua/napryamki/programi-rozvitku-apk/regionalni-programirozvitku-agropromislovogo-kompleksu (дата звернення : 07.10.2019).

23. Про програму фінансової підтримки органічного виробництва в Чернігівській області на 2015-2020 pр. : Рішення Чернігівської обласної ради від 29 квітня 2015 р. URL : $\quad$ https ://chor.gov.ua/normativni-dokumenti/rishennya/item/2803-proprohramufinansovoi-pidtrymky-orhanichnoho-vyrobnytstva-v-cher (дата звернення : 07.10.2019).

\section{References}

1. "World Organic Statistics 2019”, available at : http ://organicinfo.ua/statystyka_2018.html (accessed : 07.10. 2019).

2. "On approval of the Concept of the State Target Program for the Development of the Agricultural Sector of the Economy for the Period up to 2020" : Order of the Cabinet of Ministers of Ukraine dated December 30, 2015, no. 1437-p, available at: https ://www.kmu.gov.ua/en/npas/248907971 (accessed 07/10/2019).

3. “Constitution of Ukraine” : Law of Ukraine of June 28, 1996 № 254k / 96-BP, available at : https ://zakon.rada.gov.ua/laws/show/254k/96-vr (accessed : 07.10.2019).

4. "On basic principles and requirements for food safety and quality": Law of Ukraine of December 23, 1997 № 771/97-BP, available at : https ://zakon.rada.gov.ua/laws/show/771/97-vr (accessed : 07.10.2019).

5. Ovcharenko, A. S., (2017), "International and regional programs of support and promotion of organic production", Naukovyi visnyk Mizhnarodnoho humanitarnoho universytetu. Ser. : Ekonomika, no. 28, pp. 42-46.

6. Overkovska, T. K., (2017), "Legal signs of organic production of agricultural products in Ukraine", Pidpryiemnytstvo, hospodarstvo i pravo, no. 11, pp. 94-98.

7. "On the Strategy of Sustainable Development "Ukraine - 2020": Presidential Decree №. 5/2015 of 12.01.2015, available at: https ://zakon1.rada.gov.ua/laws/show/5/2015 (accessed : 07.10.2019).

8. "On the basic principles and requirements for organic production, circulation and labeling of organic products": Law of Ukraine of 10.07.2018 № 2496-VIII, available at: https ://zakon5.rada.gov.ua/laws/show/2496-viii (accessed 07.10.2019).

9. “On the Protection of Animals from Cruelty” : Law of Ukraine of 21.02.2006 №. 3447-IV. Journal of the Verkhovna Rada of Ukraine, 2006, no. 27, art. 230.

10. Zakharov, D. Ye. (2010), "Animals as objects of civil rights", Thesis abstract for Cand. Sc. (Jurisprudence), 12.00.03, Ekaterinburg, Russia.

11. Kurman T. V., (2018), "Problems of legislative support for the production of organic livestock products". Pidpryiemnytstvo, hospodarstvo i pravo, no. 12, pp. 153-157.

12. Vorobyova (Magomedova), T. M., (2018) "The concept of land plots for growing livestock feeds and their place in the land of Ukraine", Pravo i suspilstvo, no. 5, vol. 1, pp. 126-131.

13. "On approval of detailed rules for the production of organic products (raw materials) of 
animal origin": Resolution of the Cabinet of Ministers of Ukraine dated 24.03.2016 No. 241, available at: https : //zakon.rada.gov.ua/laws/show/241-2016- n (date of access : 07.10.2019).

14. "On breeding business in animal husbandry": Law of Ukraine of December 15, 1993 №. 3691-XII, available at: https ://zakon.rada.gov.ua/laws/show/3691-12 (accessed : 07.10.2019).

15. Urkevych, V. Yu. and Shulha, M. V. (2013), Aktualni problemy pravovoho zabezpechennia prodovolchoi bezpeky Ukrainy [Aktualni problemy pravovoho zabezpechennia prodovolchoi bezpeky Ukrainy], Kharkiv, Ukraine.

16. Hryhorieva, Kh. A., (2019), Derzhavna pidtrymka silskoho hospodarstva Ukrainy: problemy pravovoho zabezpechennia [State support of agriculture of Ukraine : problems of legal support], Helvetyka, Kherson, Ukraine.

17. "On approval of the Procedure of using the funds provided in the state budget for support of livestock, storage and processing of agricultural products, aquaculture (fisheries)": Resolution of the Cabinet of Ministers of Ukraine dated 7.02.2018 № 107, available at : https : //zakon.rada.gov.ua/laws/show/en/107-2018-n (accessed 07.10.2019).

18. "On the allocation of funds provided in the state budget under the program 2801540 "State support for animal husbandry, storage and processing of agricultural products, aquaculture (fisheries)" for 2019": Order of the Cabinet of Ministers of Ukraine dated 27.03.2019 № 196-p, available at : https ://zakon.rada.gov.ua/laws/show/196-2019-r (accessed : 07.10.2019).

19. On the Comprehensive Program for the Development of the Agroindustrial Complex of Volyn Region for 2016-2021 : Decision of the Volyn Regional Council of 10.03.2016 No. 3/23, available at: http://agrovolyn.gov.ua/article/kompleksna-programama-rozvytkuagropromyslovogo-kompleksu-volynskoyi-oblasti-na-2016-2021-roky

(accessed : 07.10.2019).

20. "About the Program of development of the agro-industrial complex of the Zhytomyr region for 2016-2020": decision of the Zhytomyr regional council №. 938 of 07.03.2018, available at : https ://zt.gov.ua/index.php/ofitsijni-dokumenti/normativedocuments/rishennya-oblasnoji-radi/11638-№-938-about-program-development-agroindustrial-complex-zhytomyr-oblast-on-2016-2020-years.html (accessed : 07.10.2019).

21. "On the Comprehensive Program for the Development of Agroindustrial Complex and Rural Territories of the Ivano-Frankivsk Region for 2016-2020" : Decision of the IvanoFrankivsk Regional Council of October 16, 2015 №. 1830-39 / 2015, available at: http ://www.if.gov.ua/files/uploads/COMPLETE\%20PROGRAM_-fin.pdf （accessed : 07.10.2019).

22. "Regional agro-industrial development programs", Ministry of Agrarian Policy and Food of Ukraine, available at: https ://minagro.gov.ua/ua/napryamki/programi-rozvitkuapk/regionalni-programi-rozvitku-agropromislovogo-kompleksu (accessed : 07.10.2019).

23. "On the program of financial support for organic production in the Chernihiv region for 2015-2020": decision of the Chernihiv regional council of 29.04.2015, available at: https ://chor.gov.ua/normative-dokumenti/rishennya/item/2803-pro-prohramufinansovoipidtrymky-orhanichnoho-vyrobnytstva-v-cher (accessed 07.10.2019). 


\section{РОЗДІЛ ІІ. ЦИВІЛЬНЕ ПРАВО ТА ЦИВІЛЬНИЙ ПРОЦЕС; МІЖНАРОДНЕ ПРИВАТНЕ ПРАВО}

УДК 347.9:35.073.533(477)

DOI https://doi.org/10.26661/2616-9444-2019-2-03

\section{Нормативний аналіз реалізації принципу гласності в цивільному судочинстві України}

Алімов К. О., Щипанова О. О.

Запорізький наџіональний університет, вул. Жуковського, 66, Запоріжжя, Україна alimova.alesya@gmail.com

\section{Ключові слова: принц̧ип \\ судочинства, реалізація приничипу гласності.}

Надійшло до редколегії:

20.08.2019

Прийнято до друку: 23.09.2019
Процесуальному законодавству кожної держави, зокрема України, притаманна така його виразна риса, як мінливість, за якої один закон замінює інший, одна зміна тягне за собою подалыші зміни. Спостерігаючи за цим процесом з часів незалежності нашої країни, можемо дійти висновку, що більш-менш сталим залишається одне, а саме принципи судочинства.

Одним із найдавніших в історії права України є принцип гласності цивільного судочинства, про що свідчать багато наукових історичних джерел. Проте нині питання, пов'язані з реалізацією цієї засади, досі привертають увагу правників і сильно поширені серед науковців, адже будь-які зміни, що вносяться, зокрема, до Цивільного процесуального кодексу України, мають відповідати принципу гласності й не суперечити йому. Найважливішим у цьому $\epsilon$ його реалізація, тобто можливість застосування та ймовірні обмеження щодо учасників справи. 3 огляду на нещодавно внесені до вищезазначеного закону зміни розгляд $\epsilon$ актуальним.

У статті розглянуто сутність реалізації принципу гласності у цивільному судочинстві України, його зміст, особливості правової регламентації чинним законодавством держави.

\section{Regulatory analysis of realization of the principle of glasses in the civil commission of Ukraine}

Alimov K. O., Shchypanova O. O.

Zaporozhia National University, str. Zhukovskogo, 66, Zaporozhia, Ukraine alimova.alesya@gmail.com

Key words: principle of publicity of the civil rule-making, realization of principle of publicity.
The procedural law of every state, including Ukraine, is characterized by its distinctive feature as variability - one law replaces another; one change entails the following changes. Observing this process since the independence of our country, we can conclude that more or less constant remains one thing - the principles of justice.

One of the oldest in the history of Ukrainian law is the principle of the publicity of civil justice, as evidenced by many scientific historical 
sources. However, to date, issues related to the implementation of this framework are attracting the attention of lawyers and are widespread in the work of scientists. After all, any changes that are made, in particular to the Civil Procedure Code of Ukraine, must comply with the principle of publicity and not contradict it. And the most important in this is its implementation, the possibility of application and possible restrictions on the participants in the case. Given the recent changes to the above law, the review is up-to-date.

In the article examined author's realization of principle of publicity of the civil rule-making of Ukraine, its content, features of legal regulation by the current legislation of the state.

Питання реалізації принципу гласності у цивільному судочинстві України розглядали у своїх працях такі вчені, як В.А. Бігун, О.Б. Верба-Сидор, Г.С. Волосатий, О.О. Гаврилюк, В.В. Городовенко, О.П. Іванченко, В.М. Кампо, С.В. Ківалов, Т.М. Кілічава, В.В. Комаров, В.М. Кравчук, В.А. Кройтор, Р.Я. Лемик,

Н.П. Лукашова,

А.О. Маляренко, О.О. Овсяннікова, В.О. Работинська, Н.Ю. Сакара, С.В. Сеник, B.O. Серьогін, B.C. Стефанюк, В.Е. Теліпко, B.I. Тертишніков, Г.П. Тимченко, С.Я. Фурса, Ю.С. Червоний. Принцип гласності судочинства належить до категорії міжгалузевих, отже, притаманних усім галузям процесуального права. Це положення законодавчо закріплене ст. 129 Конституції України, в якій зазначено, що основними засадами судочинства $\epsilon$ гласність судового процесу та його повне фіксування технічними засобами [1]. Проте у цивільному процесі, на відміну від кримінального та адміністративного, йому притаманні свої особливості.

Найбільш повно засада гласності цивільного процесу регламентована у ст. 7 Цивільного процесуального кодексу України (далі - ЦПК). Однак сама стаття не містить дефініції цього поняття. Законодавець у ч. 1 досліджуваної статті Кодексу дав лише невелике роз'яснення, яким суд та інші учасники цивільного процесу мають керуватися під час розгляду справи у суді: «Розгляд справ у судах проводиться усно і відкрито, крім випадків, передбачених Кодексом» [2]. Отже, усність і відкритість $\epsilon$ визначальними поняттями, які слід мати на увазі під час застосування принципу гласності в цивільному судочинстві. Проте вичерпне його розуміння набагато ширше, адже воно включає основні поняття; коло учасників процесу, до яких застосовується і які застосовують цей принцип; фіксацію судового засідання за допомогою технічних засобів; надання доступу до судових рішень; відкритий доступ до інформації про дату, місце та час судових засідань; обмеження у реалізації тощо. Через це тлумачення ст. 7 Цивільного процесуального Кодексу у кожному конкретному випадку різнитиметься, що насамперед залежить від рівня правової освіти та досвіду роботи юриста, який застосовує це поняття під час розгляду справи судом. Розуміння поняття «Гласність» суттєво різниться серед науковців. О.Б. Верба-Сидор зміст принципу гласності у своїй праці виклала досить лаконічно: «відкритість судового розгляду полягає в тому, що усі цивільні справи в усіх судових інстанціях розглядаються публічно» [3, с. 34]. Більш повно описав засаду гласності B.Е. Теліпко. На його думку, відкритий розгляд означає встановлений процесуальним законом порядок розгляду справ у судах, за якого судові засідання проводяться відкрито з наданням реальної й рівної можливості громадянам, які цікавляться справою, бути присутніми в залі, стежити за ходом судового розгляду, конспектувати, стенографувати те, що відбувається, використовувати портативні аудіотехнічні пристрої (кіно-, фото- та відеозйомка із застосуванням стаціонарної 
апаратури провадяться тільки 3 дозволу суду й учасників процесу) [4]. Іншу думку має Т.М. Кілічава, що вважає, що принцип гласності характеризує демократизм цивільного судочинства i сприяе здійсненню ним запобіжної i виховної функцій. В.В. Городовенко вважає, що гласність $€$ вужчим поняттям, ніж доступність до правосуддя, яке традиційно означає свободу доступу громадян до залів судових засідань [6, с. 39]. Іншої думки дотримується О.О. Гаврилюк, який стверджує, що гласність, а саме відкритість судового розгляду, - це чіткий та прозорий судовий процес, який $є$ зрозумілим не лише для його учасників, але й для громадськості [7, с. 50].

Як бачимо, думки науковців схожі, але водночас різняться між собою. У кожному 3 наведених висловлювань автори дають визначення досліджуваного принципу, виходячи з різних позицій, що зумовлює відмінність їхніх точок зору. Одні розглядають засаду гласності у вузькому, а інші - у широкому розумінні. Проте є дещо спільне, що об'єднує ці думки, а саме сутність принципу, яка полягає у його публічності, тобто доступності суспільству. Шляхи цієї доступності кожен розуміє неоднаково, виходячи 3 особливості суспільних відносин, в яких застосовується засада гласності.

Говорячи про шляхи реалізації принципу гласності, перш за все звертаємо увагу на те, що слід розуміти під поняттями «усність» та «відкритість». У цьому разі застосування звукової форми слів може бути виражене у:

1) перевірці секретарем судового засідання тих, хто з'явився у судове засідання, а також оголошенні ним фраз на кшталт «Встати, суд іде»;

2) зачитуванні сутності справи, яка розглядається, суддею одноособово чи колегією суддів;

3) 3'ясуванні обставин справи шляхом допиту свідків, ознайомлення 3 доказами по справі, їх демонстрації;
4) здійсненні перекладу показань учасника судового процесу, доказів, наданих суду перекладачем;

5) оголошенні висновку експерта;

6) проведенні судових дебатів;

7) оголошенні судом рішення, винесенні ухвал тощо.

Регламентацію принципу гласності можна дослідити серед таких нормативноправових актів, як Конституція України, Цивільний процесуальний кодекс України, Закони України «Про судоустрій та статус суддів», «Про доступ до судових рішень», Постанова Кабінету Міністрів України «Про затвердження Порядку ведення Єдиного державного реєстру судових рішень». Усі вони містять положення, які тим чи іншим чином регулюють відносини, які виникають під час реалізації принципу гласності. Зазначеними нормативними актами передбачені права, якими наділені, окрім учасників цивільного процесу, звичайні пересічні громадяни, а також обмеження, тобто так звані заборони, які дещо звужують осіб, які $\epsilon$ або потенційно можуть бути учасниками цього процесу, щодо реалізації їх правомочностей. Отже, йдеться про шляхи реалізації принципу гласності у цивільному судочинстві. Існує такі три напрями застосування принципу гласності:

- використання суб'єктивного права, якими наділені громадяни;

- виконання юридичного обов'язку;

- дотримання приписів законодавства про судочинство.

Кожен із перелічених елементів має власні, тобто притаманні лише йому, особливості, тому розглянемо їх детальніше.

Першим елементом реалізації принципу гласності $є$ використання суб'єктивного права. Найбільш повно зазначених вище суб'єктів наділяє правами гласності Цивільний процесуальний кодекс України. Йдеться про ст. 7 Кодексу. Для того щоби більш повно проаналізувати перший елемент 
реалізації принципу гласності, ми пропонуємо виокремити таких трьох суб'єктів цивільно-процесуальних правовідносин, які наділені правомочностями:

1) суд як державний орган, який вершить правосуддя, в особі судді або колегії суддів;

2) особи, які беруть участь у процесі, зокрема сторони, свідки;

3) інші суб'єкти, зокрема вільні слухачі, звичайні громадяни.

Суд $\epsilon$ основною й найголовнішою ланкою в цивільно-процесуальних відносинах, оскільки на нього покладається функція правосуддя у державі. Саме він уповноважений розглядати й вирішувати цивільні справи по суті. Це має наслідком велику відповідальність, оскільки рішення, ухвала, постанова судді породжують юридичні наслідки. Для того щоби ухвалити правильне рішення по справі, дуже важливо не тільки дотриматися, але й правильно застосувати дозвільні норми права, які містяться у чинному законодавстві. Задля цього упорядники Цивільного процесуального кодексу України, зокрема, ретельно прописують його положення, наділяючи органи правосуддя певними правами.

Аналізуючи ст. 7 Цивільного процесуального кодексу України, можемо виділити такі групи правомочностей суду.

По-перше, суд може видалити із зали судових засідань осіб, які перешкоджають веденню судового засідання, здійсненню прав або виконанню обов'язків учасників судового процесу чи судді, порушують порядок у залі суду [2; 9]. У Цивільному процесуальному кодексі старої редакції ця правомочність містилась лише у главі під назвою «Заходи процесуального примусу», а саме у ст. 92 [2]. Логічним постає питання про те, чому законодавець у Кодексі нової редакції дублює це право (окрім ст. 145) саме у статті, яка регламентує гласність, адже зміст цих двох статей майже однаковий. Відповідь можна пояснити таким чином. Як ми зазначали раніше, гласність оперується поняттями «відкритість» та «усність». Порушення порядку під час судового засідання веде до порушення прав учасників процесу, а також нормальної діяльності суду під час розгляду та/або вирішення справи по суті. За таких умов можна допустити думку про те, що усний розгляд справи переривається, що відволікає всіх присутніх у залі судового засідання від суті справи, особливо це відволікає суддю, який повинен за результатами допиту свідків, дослідженням доказів ухвалити правильне рішення. Проте, на нашу думку, важко відокремлювати ці дві статті одну від одної, адже на практиці під час їх застосування можлива конкуренція норм. Хоча у ч. 5 ст. 7, на відміну від ст. 145, відсутнє попередження головуючого, яке передує видаленню особи із зали судового засідання в разі порушення нею порядку під час розгляду справи. У ст. 145 є додаткове порушення, що полягає у невиконанні розпоряджень головуючого, яке відсутне у ч. 5 ст. 7 Цивільного процесуального кодексу [2]. Інші ж положення цих двох статей однакові, тому законодавцю варто звернути увагу на цей недолік у законі.

По-друге, суд може дозволяти трансляцію судового засідання (ч. 5 ст. 7 ЦПК) [2]. При цьому суд обов'язково враховує думки учасників справи та можливості здійснення такої трансляції без шкоди для судового розгляду. Частіше за все суди здійснюють пряму трансляцію, тобто безпосередню трансляцію судового засідання по телебаченню чи радіо без попереднього запису та монтажу. Задля цього у мережі Інтернет на офіційному порталі «Судова влада України» $\epsilon$ окремий розділ, присвячений цьому. Більш того, на цьому сайті $\epsilon$ архів, у якому розміщені всі справи, які транслювалися раніше, а також заплановані трансляції зі вказівкою точної дати та часу ii проведення. Зручність порталу полягає в тому, що кожен 
бажаючий може в онлайн-режимі спостерігати за проведенням судового засідання. Говорячи про архів трансляцій судових засідань, звертаємо увагу на той факт, що «Судова влада України» на "Youtube" має власний однойменний канал, на якому розміщені всі записи судових засідань, які раніше транслювалися в онлайн-режимі. Статистика цього каналу свідчить про його невелику популярність. За три роки існування зазначеного веб-сайту загальна кількість переглядів відео, опублікованих там, становить 752 тисячі [10]. Стосовно підписників, які постійно стежать за новинами «Судової влади України», то їх налічується 1,4 тисячі осіб [10]. Проте ці показники все ж таки свідчать про те, що суспільство виявляє інтерес до судового процесу, зокрема цивільного.

По-трете, суд може оголосити судове засідання закритим повністю або закритою його частину, про що виноситься окрема ухвала [2; 9].

По-четверте, суд може визначити місце в залі судових засідань, 3 якого мають проводитися фотозйомка, кінозапис [2; 9].

Як бачимо, суд як державний орган, що здійснює правосуддя, наділений широкими повноваженнями у сфері гласності судочинства. Окрім цього, він усебічно використовує надані йому законами правомочності. Саме тому реалізацію певних прав суду нині може бачити будь-яка особа, навіть не виходячи за межі власного житла.

Наступними суб' єктами цивільнопроцесуальних правовідносин, які наділені специфічними правомочностями, $\epsilon$ особи, які беруть участь у судовому процесі. Вони мають таку групу прав.

Право безперешкодно отримувати інформацію, яка $є$ відкритою, про суд, який розглядає справу, сторони спору та предмет позову, дату надходження позовної заяви, апеляційної, касаційної скарги, заяви про перегляд судового рішення, стадії розгляду справи, місце, дату й час судового засідання, рух справи
3 одного суду до іншого [9]. Крім того, користувачі можуть отримувати витяги необхідних їм даних. Така інформація розміщується на офіційному веб-порталі судової влади України й підлягає негайному оприлюдненню, крім випадків нерозголошення даних щодо закритого судового засідання.

Право заявляти клопотання про розгляд справи у закритому судовому засіданні задля забезпечення таємниці усиновлення, запобігання розголошенню відомостей про інтимні чи інші особисті сторони життя учасників справи або відомостей, що принижують їхню честь і гідність, а також в інших випадках, установлених законом [2].

Право проводити у залі судового засідання фотозйомку, відео- та аудіозапис 3 використанням портативних відео- та аудіотехнічних засобів без отримання окремого дозволу суду, але 3 урахуванням обмежень, встановлених ЦПК [2; 9]. Такі обмеження можуть стосуватися лише випадків проведення судового засідання закритого типу, за якого забороняється здійснення будьякого технічного запису ходу розгляду справи.

Право давати згоду на оголошення в судовому засіданні змісту особистих паперів, листів, записів телефонних розмов, телеграм та інших видів кореспонденції [2]. Зазначені повідомлення долучаються до справи для розгляду iï судом тоді, коли вони містять будь-які докази, які мають значення для вирішення справи. Водночас інформація, дані, які містяться в такій кореспонденції, не підлягають розголошенню. ЦПК при цьому посилається на ЦКУ, чим наголошує на тому, що згода на вчинення цієї дії має бути отримана від особи, яка направила будь-який із перелічених вище видів кореспонденції, та адресата. У ст. 306 Цивільного кодексу України зазначається, що якщо кореспонденція стосується особистого життя іншої фізичної особи, то для іiі використання потрібна згода цієї особи. У разі смерті 
фізичної особи, яка направила кореспонденцію, й адресата використання кореспонденції $\epsilon$ можливим лише за згодою їхніх дітей, вдови (вдівця), а якщо їх немає, то батьків, братів та сестер [11]. Це ж правило застосовується під час дослідження звуко- й відеозаписів такого самого характеру.

Аналізуючи перелічені вище права осіб, які беруть участь у цивільному процесі, можемо зробити висновок про те, що вони більше пов'язані 3 питанням можливості проведення закритого судового засідання. Саме таким чином засада гласності знаходить свій вияв.

Завершує аналіз реалізації принципу гласності шляхом використання суб'єктивного права характеристика інших осіб, не причетних до цивільного судочинства. Найяскравішим прикладом таких суб'єктів є вільні слухачі, присутні на судових засіданнях, а також громадяни загалом. Перелік їхніх прав можна представити таким чином.

Будь-яка особа має право бути присутньою у відкритому судовому засіданні [2; 9]. Ця теза означає, що бажаючі можуть відвідати будь-яке судове засідання (окрім випадків, коли воно закрите), у будь-якому місті незалежно від власного місця реєстрації та проживання. Причому кількість відвідування подібних засідань законодавством не обмежується. Іноземні громадяни та апатриди також можуть бути присутні у судових засіданнях як вільні слухачі, адже Основним Законом нашої держави встановлено, що зазначені особи за умови, що вони перебувають в Україні на законних підставах, користуються тими самими правами й свободами, а також несуть такі самі обов'язки, як i громадяни України, за винятками, встановленими чинним законодавством [1]. Оскільки норми ЦПК не містять прямої заборони, а зазначають, що будь-яка особа може бути присутньою у судовому засіданні, то це право поширюється на інших осіб, які не $€$ громадянами України. Норма ЦПК, яка регламентує присутність особи у судовому засіданні, не має обмежень стосовно віку людини під час iï допуску до зали суду. Однак якщо присутність певних осіб заважає досягненню цілей судочинства, то суд задля встановлення порядку в залі судового засідання вправі видалити цих осіб.

Особи, присутні в залі судового засідання, представники засобів масової інформації можуть проводити у залі судового засідання фотозйомку, відео- та аудіозапис $з$ використанням портативних відео- та аудіотехнічних засобів без отримання окремого дозволу суду, але 3 урахуванням обмежень, зазначених вище $[2 ; 9]$.

Останнім елементом реалізації принципу гласності в цивільному процесі $\epsilon$ дотримання приписів законодавства про судочинство. Вони мають загальну назву, а саме «Забороняючі норми», які прямо в законі зазначають, що вчинення тих чи інший дій $€$ неприпустимим, має наслідком настання юридичної відповідальності та вжиття заходів примусу до осіб, які ці приписи порушили. Законодавство України, яке регламентує порядок здійснення судочинства, містить такі приписи.

Під час проведення в залі судового засідання фотозйомки, відеозапису, а також трансляції судового засідання особами, які це здійснюють, не мають створюватися перешкоди у веденні засідання та здійсненні учасниками судового процесу їхніх процесуальних прав [2; 9]. За порушення цих правил до осіб судом буде вжито заходів процесуального примусу (від попередження до накладення штрафу).

Від особи, яка бажає бути присутньою у судовому засіданні, забороняється вимагати будь-які документи, крім тих, що посвідчують особу, зокрема ними можуть бути паспорт, студентський квиток [2]. Значення цієї заборони полягає в тому, що суд не ставить за потрібне мати відвідувачам судового засідання 
спеціальне посвідчення або інший документ, який мав би привілеї порівняно 3 іншими під час допуску особи до зали судових засідань і до цивільного процесу загалом.

У разі присутності під час розгляду справи в порядку закритого судового засідання свідків, експертів, спеціалістів, перекладачів на них покладається заборона розголошення інформації, яка таким чином стала їм відомою [2]. Суд заздалегідь попереджає зазначених осіб про цей обов'язок задля забезпечення захисту інформації, вчиняються окремі процесуальні дії в закритому судовому засіданні. За порушення збереження таємниці Кримінальним кодексом України передбачається відповідальність, зокрема розголошення таємниці усиновлення всупереч волі усиновителя (ч. 1 ст. 168) карається штрафом до п'ятдесяти неоподатковуваних мінімумів доходів громадян або громадськими роботами на строк до двохсот сорока годин, або виправними роботами на строк до двох років [12].

Під час проведення закритого судового засідання не допускається використання систем відеоконференцзв'язку та транслювання перебігу судового засідання в мережі Інтернет [2]. Ця заборона спрямована на забезпечення схоронності інформації певного виду та іiі подальшого нерозголошення, що може завдати шкоди державним, суспільним чи особистим інтересам.

Дослідивши реалізацію принципу гласності в цивільному процесі у трьох іiі аспектах, можемо зробити такі висновки. По-перше, гласність завжди оперує двома поняттями, такими як «відкритість» та «усність», які, незважаючи на різний зміст, все ж таки тісно пов'язані один 3 одним. По-друге, реалізація гласності має три форми свого існування, а саме використання суб'єктивного права, виконання юридичного обов'язку та дотримання приписів цивільного судочинства. Усі вони містяться в різних нормативних актах, які регламентують здійснення цивільного процесу різною мірою. Однак комплексно вони зосереджені у ЦПК, а саме у ст. 7, зміст якої упорядниками Кодексу цілком відповідає сутності досліджуваного принципу. $€$ лише один виняток, який стосується права суду видаляти осіб із зали судових засідань у разі порушення ними порядку під час розгляду справи. Це положення дублюється у главі «Заходи процесуального примусу». На нашу думку, недоцільним $є$ те, що законодавець відніс таку правомочність у статтю, в якій описана сутність принципу гласності. Потрете, зміст принципу гласності, аналізований нами 3 трьох боків, свідчить про те, що під час реалізації прав, яких у суб'єктів цивільного процесу достатньо, насамперед необхідно звертати увагу на те, чи не порушуватимуться активними діями одних осіб права інших осіб. Саме для врегулювання подібних відносин держава забезпечує всіх учасників судочинства гарантіями, які мають свій вияв у покладенні на них певних юридичних обов'язків та існуванні низки заборон, аби підтримувати баланс під час правовідносин у сфері здійснення правосуддя.

\section{Література}

1. Конституція України : Закон України від 28 червня 1996 року. URL: www.rada.gov.ua.

2. Цивільний процесуальний кодекс України : Закон України від 18 березня 2004 року. URL: www.rada.gov.ua.

3. Верба-Сидор О. Б., Воробель У. Б., Навроцька Ю. В. Цивільне процесуальне право України : навчальний посібник (у схемах і таблицях). Львів : Львівський державний університет внутрішніх справ, 2013. 388 с. 
4. Теліпко В. Е. Науково-практичний коментар Закону України «Про судоустрій i статус суддів». URL: https://textbook.com.ua/pravo/1474611184.

5. Кілічава Т. M. Цивільне процесуальне право. URL: http://194.44.152.155/elib/local/r166.pdf.

6. Городовенко В.В.Принцип гласності та відкритості у вітчизняному судочинстві: проблеми реалізації. Вісник Верховного Суду України. 2011 . № 9 (133). С. 38-43.

7. Гаврилюк О. О. Принцип гласності та відкритості в адміністративному судочинстві України : дис. ... канд. юрид. наук : спец. 12.00 .07 ; Міжнародний університет бізнесу і права. Херсон, 2012. 196 с.

8. Овсяннікова О.О. Генезис принципу гласності судової влади. URL: http://lj.oa.edu.ua/articles/ 2013/n2/13ooohsv.pdf.

9. Про судоустрій та статус суддів : Закон України від 2 червня 2016 року. URL: www.rada.gov.ua.

10. Судова влада України. URL: https://www.youtube.com/channel/UCFDRcAmACu5ljFYUMGctnA/about.

11. Цивільний кодекс України : Закон України від 16 січня 2003 року. URL: www.rada.gov.ua.

12. Кримінальний кодекс України : Закон України від 5 квітня 2001 року. URL: www.rada.gov.ua.

13. Про державну таємницю : Закон України від 21 січня 1994 року. URL: www.rada.gov.ua.

14. Про доступ до судових рішень : Закон України від 22 грудня 2015 року. URL: www.rada.gov.ua.

\section{References}

1. "The Constitution of Ukraine": Law of Ukraine of June 28, 1996, available at: www.rada.gov.ua.

2. "Code of Civil Procedure of Ukraine": Law of Ukraine of March 18, 2004, available at: www.rada.gov.ua.

3. Verba-Sidor, O. B., Vorobel, V. B. and Navrotskaya, Y. V. (2013), Tsyvilne protsesualne pravo Ukrainy: navchalnyi posibnyk (u skhemakh i tablytsiakh) [Civil Procedure Law of Ukraine: Textbook (in Diagrams and Tables)], Lviv State University of Internal Affairs, Lviv, Ukraine.

4. Telipko, V. E. Naukovo-praktychnyi komentar Zakonu Ukrainy "Pro sudoustrii i status suddiv" [Scientific and Practical Commentary on the Law of Ukraine "On Judicial System and Status of Judges"], available at: https://textbook.com.ua/pravka/1474611184.

5. Kilicheva, T. M. "Civil Procedure Law", available at: http://194.44.152.155/elib/local/r166.pdf.

6. Gorodovenko, V. V. (2011), "The principle of publicity and openness in domestic justice: problems of implementation", Bulletin of the Supreme Court of Ukraine, no. 9 (133), pp. 38-43. 
7. Havrylyuk, O. O. (2012), "The principle of publicity and openness in the administrative proceedings of Ukraine", Thesis abstract for Cand. Sc. (Jurisprudence), 12.00.07, International University of Business and Law, Kherson, Ukraine.

8. Ovsyannikov, O. O. "The genesis of the principle of publicity of the judiciary", available at: http://lj.oa.edu.ua/ articles/2013/n2/13ooohsv.pdf.

9. "On the Judiciary and Status of Judges": Law of Ukraine of 02 June 2016, available at: www.rada.gov.ua.

10. "Judicial power of Ukraine", available https://www.youtube.com/channel/UCFDRcAmACu5ljF-YUMGctnA/about.

11. "Civil Code of Ukraine": Law of Ukraine of January 16, 2003, available at: www.rada.gov.ua.

12. "The Criminal Code of Ukraine": Law of Ukraine of April 05, 2001, available at: www.rada.gov.ua.

13. “On State Secrets": Law of Ukraine of January 21, 1994, available at: www.rada.gov.ua.

14. "On access to court decisions": Law of Ukraine of December 22, 2015, available at: www.rada.gov.ua.

УДК 347.795.4:342.7:347.44

DOI https://doi.org/10.26661/2616-9444-2019-2-04

\section{Гарантії прав пасажира за договором перевезення пасажира}

\section{Самойленко Г. В.}

Запорізький національний університет, вул. Жуковського, 66, м. Запоріжжся, Украӥна georgesamoil1976@gmail.com

\begin{abstract}
Ключові слова:
пасажир, перевезення, забезпечення прав пасажира, здійснення прав, гарантї здійснення прав пасажиром, договір перевезення пасажира, засоби впливу на поведінку перевізника.
\end{abstract}

Надійшло до редколегії:

19.08.2019

Прийнято до друку: 23.09.2019
Стаття присвячена актуальним питанням гарантій прав пасажира як складових механізму забезпечення здійснення ним своїх прав як сторони договору перевезення пасажира та носія правомочності свободи пересування. Оскільки останні мають реалізацію в договірних правовідносинах з перевезення пасажира, то їх правове регулювання має відповідати вимогам забезпечення належного здійснення прав особою-пасажиром. Досягнення мети забезпечення прав пасажира неможливе лише шляхом застосування правових гарантій. Автор визначив рівні правових гарантій забезпечення прав пасажира, а саме загальноправові, галузеві цивілістичні, інституційні, субінституційні. В широкому значенні до гарантій слід віднести норми, умови, засоби, способи, прийоми та методи впливу на поведінку учасників правовідносин 3 перевезення пасажира, щоби права пасажира було дотримано, забезпечено їх здійснення пасажиром. Вони застосовуються на стадіях нормування, регулювання, здійснення та правозахисту. Серед останніх слід назвати правову регламентацію прав пасажира, застосування зобов'язань, приписів, дозволів, заборон, правових обмежень, стягнень та стимулів.

Автор робить висновок, що окремі гарантії забезпечення прав 
пасажира за законодавством України не відповідають підходам ЄC, відповідно, не забезпечують очікуваної від них ефективності.

\title{
Passenger rights guarantees under the contract of carriage of the passenger
}

\author{
Samoylenko G. V. \\ Zaporizhia National University, Zhukovskogo str., 66, Zaporizhia, Ukraine \\ georgesamoil1976@gmail.com
}

\section{Key words:}

passenger, carriage, securing of passenger rights, exercising of rights, guarantees of exercising of passenger rights, contract of carriage of passengers, means of influencing the behavior of the carrier.
The article is devoted to current issues of passenger rights guarantees. These guarantees are part of the mechanism for ensuring the passenger's exercise of his rights. In doing so, the passenger is the bearer of the entity's general authority and a party to the contract of carriage, in which the general authority receives a "special manifestation". A person exercising his right to freedom of movement on a paid basis by means of a vehicle belonging to another person is a passenger. Therefore, the rights of the passenger must be secured as a party to the contract and as a person exercising his natural right through the efforts and means of the carrier. In other words, the personal non-proprietary rights of the passenger must be secured and protected.

The concept that the carrier is only obliged to carry the passenger no longer meets current requirements. The content and scope of passenger rights is much broader: it is also a matter of safety, comfort, cleanliness and timeliness. At the same time the passenger wants to feel respect and attention, care. And this is true, since the passenger confides in the carrier his life and health, he expects the need to move properly to be met. In these matters, the passenger relies entirely on the carrier.

That is why ensuring the rights of the passenger (respecting the rights of the passenger and creating the conditions for exercising their rights, the ability to protect the rights) should be based on legally defined legal guarantees. In other words, the "ideal model" of carrier and passenger behavior, the rights of the passenger and the conditions for their proper implementation should be enshrined in regulations. Ensuring this model of carrier behavior is achieved through guarantees. However, contractual liability is an important, key but not the only guarantee of the proper conduct of the parties involved in the carriage of passengers.

If at the level of theoretical research the idea of human-centricity begins to come to fruition, unfortunately, it is not fully implemented in the current legislation. The legal regulation of the carriage of passengers on a humanistic basis will help to ensure the rights of the passenger. However, it is not possible to secure the rights of the passenger with one civil guarantee. It is only through the application of a comprehensive approach, common law instruments (legal, organizational, economic, etc.) that the goal can be achieved.

The levels of legal guarantees of ensuring the rights of the passenger are distinguished: constitutional, sectoral civility, institutional, subinstitutional. The author determines that, in the broad sense, the guarantees should include: rules, conditions, means, methods, techniques and methods of influencing the behavior of participants of the legal relationship for the carriage of the passenger so that the rights of the passenger are respected, ensured their exercise by the passenger. The latter include the legal regulation of passenger rights, the application 
of obligations, prescriptions, permits, prohibitions, legal restrictions, penalties and incentives.

Of course, the proper performance of the contract of carriage of the passenger by the carrier should result in satisfying the expectations of the passenger from the contract, satisfying his need to move in a way that respects other rights of the passenger (first of all, personal nonproperty rights) and not degrading human dignity. Other safeguards: the protection of violated rights and civil liability fulfill the inherent functions of preventing the infringement and compensating for the harm caused.

The author concludes that the guarantees of passenger rights under the legislation of Ukraine do not correspond to the EU approaches and, accordingly, do not provide the expected efficiency from them.

Застосування функціонального прагматичного підходу дає змогу зробити закономірний висновок щодо того, що ступінь ефективності забезпечувальних засобів прав пасажирів $\epsilon$ невідповідним їх потребам. Основним аргументом $\epsilon$ наявність великої кількості порушень пасажирів, зокрема дітей, осіб 3 інвалідністю, пасажирів пільгових категорій. Отже, виникає логічне усвідомлення того, що $є$ потреба вдосконалення механізму правового регулювання перевезень пасажирів, який містив би надійні гарантії дотримання прав пасажира й людини, забезпечення їх здійснення (на рівні створення умов, сприятливих для такого здійснення, механізму захисту на випадок порушення прав пасажира).

Як в теорії цивільного права, так і в цивільному та спеціальному транспортному законодавстві провідною $€$ ідея цивільно-правової відповідальності перевізника як інструменту забезпечення прав пасажира.

Вважаємо, що такий підхід $\epsilon$ кардинально неправильним. Цивільноправова відповідальність має усвідомлюватися як кінцева стадія на етапі правозахисту, як виключний інструмент, що використовується тоді, коли право пасажира вже $\epsilon$ порушеним. Насправді всі зусилля мають докладатися до правової охорони, забезпечення умов належного виконання договірного зобов'язання, отже, дотриманню прав пасажира, сприянню пасажиру в можливості здійснення своїх прав.
Попри те, що останнім часом вже здійснено низку дисертаційних досліджень правовідносин, пов'язаних 3 діяльністю транспорту, основна увага приділена все ж таки окремому виду перевезень, а саме перевезенням вантажів. Звичайно, на загальнотеоретичному рівні наукову увагу сфері перевезень приділили В.В. Луць, В.І. Борисова, О.В. Дзера, Н.С. Кузнєцова, Р.А. Майданик, С.О. Погрібний, Р.О. Стефанчук, С.О. Харитонов, Я.М. Шевченко, Р.Б. Шишка, І.В. Булгакова, О.В. Клепікова, Е.Ф. Демський, В.К. Гіжевський, С.Е. Демський, А.В. Мілашевич, Г.В. Чурпіта.

Серед дослідників правовідносин 3 перевезення пасажирів слід відзначити таких, як А.О. Мінченко, О.М. Нечипуренко, Д.С. Абрикосов, С.О. Сумкін, У.П. Гришко, I.C. Лукасевич-Крутник.

Попри наявність досліджень зазначених авторів, основна увага яких приділена цивільно-правовому регулюванню перевезень пасажирів, належна увага питанням забезпечення прав пасажира не була приділена.

3 огляду на те, що інструментами забезпечення прав пасажира $€$ гарантії, вибираємо напрям дослідження.

Ми не маємо ілюзій щодо того, що лише цивільно-правовими засобами, гарантіями можна забезпечити права пасажира. Звичайно, велике значення мають економічні, соціальні, організаційні гарантії. Саме комплексний підхід має сприяти досягненню мети забезпечення прав пасажира. До того ж ці гарантії мають бути складовими, умовами, 
інструментарієм механізму правового регулювання на кожній ऑiі стадії. При цьому кожен із зазначених чинників відіграє важливу роль, а лише у їх взаємодії $\epsilon$ можливим досягнення результату забезпечення прав пасажира.

В дослідженні маємо на меті 3'ясувати цивільно-правові гарантії забезпечення прав пасажира, їx ефективність, види та зміст, взаємозв'язок, сформулювати пропозиції щодо їх удосконалення.

Пасажир $є$ стороною договору перевезення та носієм загальних правомочностей. Останні в договірному правовідношенні отримують особливий прояв. Особа, яка здійснює своє право на свободу пересування на платній основі за допомогою транспортного засобу, належного іншій особі (перевізникові), є пасажиром, тому права пасажира мають бути забезпечені не лише як суб'єктивні права сторони договору, але й як людини, яка здійснює своє природнє право зусиллями та засобами перевізника. Іншими словами, особисті немайнові права пасажира мають бути охоронюваними, забезпеченими та захищеними.

Підхід, за якого перевізник має лише обов'язок перевезти пасажира, вже не відповідає сучасним вимогам. Зміст та об'єм прав пасажира є значно ширшим: це питання й безпеки, й комфорту, й чистоти, й своєчасності. Притому пасажир бажає відчувати повагу, увагу, турботу. Це справедливо, оскільки він ввіряе перевізнику своє життя й здоров'я, очікує на належне задоволення своєї потреби щодо переміщення. В цих питаннях пасажир повністю покладається на перевізника, тому останній повинен задовольнити зазначені очікування, оскільки йдеться про людську гідність та права людини, а не лише про суб'єктивні права пасажира за договором.

Саме тому забезпечення прав пасажира (дотримання прав пасажира та створення умов для здійснення ним своїх прав, можливість захисту прав) має грунтуватися на нормативно визначених правових гарантіях.

Гарантії $є$ складовими механізму забезпечення здійснення пасажиром своїх прав. Вони є необхідними в конструкції публічного договору про приєднання. Ці гарантії полягають у закріпленні «ідеальної моделі» поведінки перевізника та пасажира, закріпленні права пасажира та створенні умов для їх належного здійснення та захисту.

Проте нині єдиного наукового підходу до сутності забезпечення, гарантій як складових забезпечення, їх місця в механізмі цивільно-правового регулювання не вироблено.

Так, А.Ю. Олійник висловився, що під забезпеченням конституційних прав i свобод варто розуміти створення сприятливих умов для їх здійснення, охорони та захисту суб'єктивних прав від їх порушення; відновлення порушеного права компетентними органами шляхом здійснення матеріальних та процесуальних юридичних засобів [1, c. 153]. О.I. Наливайко вважає, що під забезпеченням прав людини слід розуміти діяльність державних органів зі створення умов (гарантій) для правомірної та неухильної їх реалізації та захисту [2, c. 22].

У сфері цивільних правовідносин O.С. Йоффе запропонував під забезпеченням розуміти такі заходи, вжиття яких відбувається для виконання договірного зобов'язання, які мають не загальний, а спеціальний характер i застосовуються не до всіх, а лише до тих зобов'язань, для яких вони встановлені законом або домовленістю сторін [3, c. 475$]$.

М.В. Вітрук вважає, що забезпечення прав i свобод можна розуміти як систему їх гарантування; як систему загальних умов і спеціальних юридичних засобів, які забезпечують їх правомірну реалізацію, а за необхідності охорону [4, с. 377].

В науковій літературі висловлено позицію, що під забезпеченням прав i 
свобод варто розуміти створення належних умов їх реалізації [5, с. 88] (свого роду позитивне право). Таке бачення дає змогу говорити про забезпечувальні засоби, серед яких чільне місце посідає правова охорона. За такого підходу забезпечення здійснення права та його правова охорона співвідносяться як загальне й особливе. Водночас Є.О. Харитонов висловив позицію, за якої охорона цивільних прав охоплює сукупність заходів та засобів, які забезпечують нормальний хід реалізації прав [6, с. 423].

На думку Р.Б. Шишки, складовими охорони $\epsilon$ правова норма як генокод належної поведінки; механізм впливу на порушника, що дає можливість притягнення його до цивільно-правової відповідальності; превентивні заходи, вжиття яких спрямоване на запобігання порушення права особи; захист порушеного права [7, с. 118]. В такому аспекті охорона вбачається більше негативним правом, спрямованим на недопущення порушення суб'єктивного права (забезпечення через заборону порушення та відновлення в разі порушення права).

В такому контексті забезпечення наближається до правової охорони, якщо призначення останньої розуміти не лише як запобігання порушенню суб' єктивних прав.

Загалом у працях науковців провідною стає позиція розуміння під забезпеченням засобів i способів, спрямованих на укріплення зобов'язань. А.В. Міцкевич визначив, що забезпечення здійснюється завдяки засобам, які $\epsilon$ гарантіями здійснення цивільних прав i

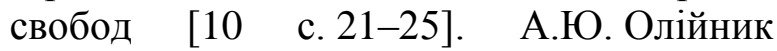
визначив гарантії здійснення прав та свобод як систему норм-принципів, умов $\mathrm{i}$ засобів, які забезпечують у сукупності здійснення цих прав та свобод [1, с. 157].

В цьому контексті С.Н. Братусем запропонована точка зору, за якої юридичні гарантії перебувають як у самих правових нормах, що спрямовані на правове регулювання шляхом встановлення прав та обов'язків учасників, так i в тих нормах, якими передбачено можливість застосування державного примусу в разі порушення суб'єктивного права, примусу до виконання нового обов'язку (йдеться про акцесорний обов'язок як обов'язок, який покладається на порушника суб' єктивного права) [9, с. 91].

Екстраполюючи наведене на сферу забезпечення прав пасажирів, визначаємо, що означені гарантії включають не лише застосування негативних наслідків до порушника прав пасажира, чим сприяють запобіганню правопорушення, відновленню матеріального становища постраждалого, але й умови, які сприяють здійсненню прав пасажиром.

За джерелами закріплення гарантій забезпечення прав пасажира варто вирізняти їх рівні, такі як загальноправові, галузеві цивілістичні, інституційні (перевезення пасажира), субінституційні (перевезення пасажира окремими видами транспорту).

Крім того, вони застосовуються на всіх стадіях правового регулювання, якими $\epsilon$ нормування, здійснення, правозахист. До їх інструментів, засобів варто віднести обмеження, зокрема ті, які зумовлені експлуатацією транспортного засобу. Так, пасажир має дотримуватися правил перевезення та вимог перевізника. Вони можуть обмежувати свободу пасажира вільного пересування шляхом заборони пересуватися транспортним засобом. При цьому, наприклад, на бортпровідниках лежить обов'язок не допускати пересування пасажирів салоном під час ввімкнення табло «Пристебнути ремені», притому відповідна заборона для пасажира відсутня, як і обов'язок виконання такої вимоги (ч. 8 п. 4 Розділу VII Правил повітряних перевезень та обслуговування пасажирів і багажу 2018 р.).

Заборони та обмеження спрямовані здебільшого на забезпечення безпеки пасажирів. Саме тому, попри їх 
негативний характер, вони є гарантіями безпеки пасажирів.

Так, пп. 3 п. 158 Правил надання послуг пасажирського автомобільного транспорту на пасажира покладається обов'язок здійснювати посадку (висадку) лише після повної зупинки автобуса; пп. 2 п. 160 Правил йому забороняється відчиняти двері транспортного засобу до повної зупинки; пп. 1 п. 149 Правил водієві адресована заборона починати рух до повного зачинення дверей та відчиняти їх до повної зупинки автобуса.

Наголошуємо на тому, що подібні вимоги відсутні на інших видах транспорту.

Непослідовним $\quad \epsilon \quad$ підхід законодавця, за якого з невідомих причин відсутня заборона пасажирові самовільно покидати салон транспортного засобу. Така заборона присутня лише на автомобільному транспорті, й то вона виражена у формі заборони самовільно відчиняти двері до повної зупинки автобуса. Проте автобус повністю може зупинятися і на світлофорі, і в очікуванні звільнення зупинки іншим автобусом.

За логікою задля забезпечення безпеки пасажирів посадка пасажирів до транспортного засобу та висадка 3 нього мають відбуватися після повної зупинки, з дозволу водія, командира, капітана, їх персоналу (стюартів, провідників, бортпровідників тощо) в призначених для цього місцях (зупинках) або принаймні не заборонених щодо цього місцях.

Отже, на нашу думку, щодо цього питання мають бути застосовані не лише інструменти приписів та зобов'язань, звернених до перевізника, але й заборона пасажирові самовільно здійснювати посадку/висадку з транспортного засобу (крім рятування, порядок здійснення якого також має бути нормативно регламентованим, а пасажира має бути поінформовано стосовно конкретного транспортного засобу (місце, спосіб та порядок евакуації)), що має бути прямо закріплено в Правилах перевезень пасажирів та транспортних статутах i кодексах, якими врегульовано перевезення різними видами транспорту.

Викликає подив обов'язок водія автобуса висадити пасажирів для здійснення заправки, тоді як те ж саме не заборонено на повітряному транспорті.

Низка обмежень прав пасажира привертають увагу. Йдеться, зокрема, про право перевізника відмовити пасажирові у здійсненні перевезення.

На різних видах транспорту застосовуються різні підходи до врегулювання наслідків перебування пасажира в стані алкогольного чи наркотичного сп'яніння, 3 небезпечними речовинами чи брудними речами або коли він порушує громадський порядок. На автомобільному транспорті йдеться про достатність однієї з підстав для відмови пасажирові у перевезенні; на залізничному - складні підстави (наявність всіх передбачених умов одночасно плюс нечіткість дефініції «у нетверезому стані»); на повітряному - теж складні підстави (стан особи та поведінка).

Окрім означеного інструментарію гарантій прав пасажира, такими варто визнати також стимули (одним 3 таких $\epsilon$ передбачення у ст.922 ЦК України підстав звільнення перевізника від цивільно-правової відповідальності, серед яких слід назвати дію обставин непереборної сили, усунення несправності транспортного засобу, яка загрожувала життю або здоров'ю пасажирів, або інших обставин, що не залежали від перевізника). Ми вже зазначали, що така підстава, як звільнення від цивільноправової відповідальності перевізника за порушення строків доставки пасажира через необхідність усунення несправності транспортного засобу, є гідною мотивацією перевізника не вдаватись до ризику експлуатувати транспортний засіб, що має несправності, особливо ті, які загрожують життю чи здоров'ю пасажирів, через загрозу бути притягненим до цивільно-правової відповідальності за затримку 
відправлення пасажира та порушення строку доставлення пасажира до пункту призначення.

До гарантій прав пасажира варто також віднести право пасажира вдатися до захисту своїх прав в один зі способів, передбачених ст. 16 ЦК України. Щоправда, специфіка правовідносин 3 перевезення пасажира полягає в регулюванні їх саме актами транспортного законодавства, які хоч i містять умови, змістом яких є права та обов'язки пасажира, перевізника, а на автомобільному транспорті - також водія, проте здебільшого не передбачають наслідків порушення прав пасажирів (притому, що шкода, завдана каліцтвом чи загибеллю пасажира, підлягає відшкодуванню в порядку, передбаченому Главою 82 ЦК України). Основними проблемами в цій сфері $є$ відсутність закріплення в актах цивільного й транспортного законодавства наслідків порушення прав пасажирів, невиконання перевізником своїх обов'язків. Навіть право пасажира відмовитися від договору провезення проведене в транспортному законодавстві неналежним чином, адже це право існує лише до моменту початку виконання договору перевізником i реалізоване лише щодо випадку добровільної відмови пасажира від перевезення, а не як наслідок істотних недоліків, істотних порушень договору (лише на повітряному транспорті в разі затримки рейсу, а на автомобільному транспорті - лише шляхом повернення вартості квитка без додаткових витрат у разі запізнення рейсу більш ніж на 1 годину (п. 83 Статуту автомобільного транспорту)), про що йдеться у ст. 10 Закону України «Про захист прав споживачів».

Застосування окремих способів захисту прав пасажира, зокрема самозахисту, нині щодо перевезення пасажирів нормативно не регламентовано, що ставить під сумнів оцінювання можливості його застосування в конкретних умовах.
Загалом складно говорити про забезпечення здійснення прав пасажиром, якщо наслідки порушення й порядок захисту такого права нормативно не регламентовано. Складно ставити питання щодо застосування такого інструменту гарантій прав пасажира, як притягнення перевізника-порушника до цивільноправової відповідальності, адже якщо збитки відсутні, неустойка щодо певного виду порушень не передбачена, а довести страждання пасажира внаслідок порушення його права (як підстави для компенсації моральної шкоди) неможливо, то відсутні умови притягнення порушника до цивільноправової відповідальності, відповідно, вдатися до захисту суб'єктивного права.

Водночас ми усвідомлюємо, що шлях нормативного закріплення наслідків порушень усіх прав пасажира, закріплених актами транспортного законодавства, є складним. Загалом у ЄС законодавець таким шляхом не пішов. Основна увага приділена створенню конкурентного середовища, яке має сформувати умови для належного здійснення прав пасажира та їх дотримання й регламентації, зокрема, щодо забезпечення мобільності, доступності, сприяння щодо перевезення, пріоритетності доставки пасажира, гідного забезпечення прав людини (доступ до вбиральні, забезпечення харчування, трансферу та готелю на випадок затримки перевезення). Це, на нашу думку, $\epsilon$ правильним шляхом. Проте, по-перше, не завжди можна створити таке конкурентне середовище. По-друге, за відсутності обов'язку надання перевізником інформації про тип та вид транспортного засобу, яким буде здійснюватися перевезення, важко вдатися до конкуренції. По-третє, як бути, якщо право пасажира порушене? Яким чином його захистити, якщо транспортним законодавством мінімізовано підстави (склади правопорушень), а також обмежено способи захисту порушеного права? 
Здається, що вихід все ж таки один, і він полягає в нормативному закріпленні наслідків порушень прав пасажирів та способів їх захисту. Вважаємо, що подібні норми-гарантії слід закріпити також у національному законодавстві.

За стадіями правового регулювання можна виділити гарантії-нормативи, гарантії охорони, гарантії здійснення, гарантії захисту. Вони виконують кілька функцій, а саме $\epsilon$ інструментами впливу на поведінку пасажира та перевізника; $є$ орієнтирами належної поведінки; $\epsilon$ маркерами модусу належного виконання договору перевезення пасажира; містять підстави та умови притягнення порушника до цивільно-правової відповідальності; визначають наслідки порушення заборон та невиконання чи неналежного виконання обов'язків перевізником; визначають порядок та способи здійснення захисту прав пасажира.

Порівнюючи забезпеченість прав пасажира за законодавством України та законодавством $\mathrm{CC}$, доходимо висновку, що національне законодавство не містить окремих гарантій прав пасажирів, а наявні не забезпечують усієї повноти палітри прав пасажирів та очікуваної від них ефективності.

\section{Література}

1. Олійник А. Ю. Конституційно-правовий механізм забезпечення основних свобод людини і громадянина в Україні : монографія. Київ: Алерта ; КНТ ; Центр навчальної літератури, 2008. 472 с.

2. Наливайко О. I. Правовий захист людини як предмет дослідження загальної теорії права. Держава і права: збірник наукових праць. Вип. 12. Юридичні і політичні науки. Київ: Інститут держави і права ім. В. М. Корецького НАН України, 2001. C. 18-24.

3. Иоффе О. С. Советское гражданское право (курс лекций). Ленинград : издательство Ленинградского университета, 1958. 512 с.

4. Загуменна Ю. О. Основні напрямки забезпечення прав і свобод людини в діяльності органів внутрішніх справ України. Форум права. 2010. № 4. С. 376-382.

5. Ієрусалімова I. O., Ієрусалимов I. O., Павлик П. М., Удовенко Ж. В. Адміністративно-правове забезпечення прав і свобод людини та громадянина: навчальний посібник. Київ : Знання, 2007. 223 с.

6. Цивільне право України: в 2 т. Т. 1: підручник / за ред. Є. О. Харитонова, Н. Ю. Голубєвої. Харків : Одіссей, 2010. 832 с.

7. Цивільне право України : підручник / за ред. Ю. Л. Бошицького, Р. Б. Шишки. Київ : Лipa-К, 2013. 760 c.

8. Анненков К.Н. Система русского гражданского права: в 3 т. Т. 3 : Права обязательственные. Санкт-Петербург : Типография М. М. Стасюлевича, 1901. 491 с.

9. Братусь С. Н. Юридическая ответственность и законность. Очерк теории. Москва : Юридическая литература, 1976. 215 с.

\section{References}

1. Oliinyk, A. Y. (2008), Konstytutsiino-pravovyi mekhanizm zabezpechennia osnovnykh svobod liudyny $i$ hromadianyna $v$ Ukraini : Monohrafiia [Constitutional-legal mechanism of ensuring basic freedoms of man and citizen in Ukraine : Monograph], Alerta, KNT, Tsentr navchalnoi literatury, Kyiv, Ukraine. 
2. Nalyvayko, O. I. (2001), "Legal protection of man as a subject of research of the general theory of law", State and Law : Collection of scientific works. Law and Political Science. Issue 12. Kyiv : Institute of State and Law. V. M. Koretsky National Academy of Sciences of Ukraine, pp. 18-24.

3. Ioffe, O. S. (1958), Sovetskoe hrazhdanskoe pravo (kurs lektsyi) [Soviet Civil Law : Lecture Course], Publisher of Leningrad University, Leningrad, USSR.

4. Zahumenna, Y. O. (2010), "The main directions of ensuring human rights and freedoms in the activity of the bodies of the Interior of Ukraine", Forum prava, no. 4, pp. 376-382.

5. Iierusalimova, I. O., Iierusalymov, I. O., Pavlyk, P. M. and Udovenko, Zh. V. (2007), Administratyvno-pravove zabezpechennia prav $i$ svobod liudyny ta hromadianyna: navchalnyi posibnyk [Administrative and legal support of human and citizen's rights and freedoms : a textbook], Znannia, Kyiv, Ukraine.

6. Kharitonov, E. O. and Golubeva, N. Y. (2010), Tsyvilne pravo Ukrainy: v 2 t. T. 1 : Pidruchnyk [Civil Law of Ukraine : in 2 volumes Vol. 1 : Textbook], Odyssey, Kharkiv, Ukraine.

7. Boshytskyi, Y. L. and Shyshka, R. B. (2013), Tsyvilne pravo Ukrainy: pidruchnyk. Zahalna chastyna [Civil Law of Ukraine : a textbook. The common part], Lira-K, Kyiv, Ukraine.

8. Annenkov, K. N. (1901), Systema russkoho hrazhdanskoho prava: V 3 t. T. III. Prava obiazatelstvennie [The system of Russian civil law : In 3 vols T. III. Rights are binding], Typohrafyia M. M. Stasiulevycha, St. Petersburg, Russia.

9. Bratus, S. N. (1976), Yurydycheskaia otvetstvennost y zakonnost. Ocherk teory [Legal responsibility and legality. Outline of the theory], Yurydycheskaia lyteratura, Moscow, USSR.

УДК 347:796:340.134(477)

DOI https://doi.org/10.26661/2616-9444-2019-2-05

To the question of defining the concept of "sport" under the legislation of Ukraine Tkalych M. O.

Zaporizhia National University, Zhukovskogo str., 66, Zaporizhia, Ukraine maxx.tkalich@gmail.com

Key words:

sports, professional sports, sports law, amateur sports, Lex Sportiva.

Надійшло до редколегії: 19.09.2019

Прийнято до друку: 23.10.2019
Throughout the development of human civilization, sport has played and continues to play a very important role. The first complexes of physical exercises and simple games have arisen already in the primitive society. In this way, skills of work were transferred, preparation for military confrontations was carried out, religious ceremonies were sent, etc.

Modern sport is a unique phenomenon that performs many different functions, including social, educational, cultural, economic, political, etc.

In particular, the term "sport" (from the English "disport" or French "desport") means "rest from work", "entertainment". Thus, sport has emerged in recent times, primarily as a way of organizing 
leisure for the aristocratic circles of European society. This process began around the middle of the eighteenth century. However, soon with the advent of the middle class, formed with the onset of the Industrial Revolution, sports was increasingly used as a way of earning money: athletes receive performance fees and spectators participate in betting money on the outcome of sports events. Over time, both of these areas of sports have evolved into amateur (amateur) and professional sports. Amateur athletes engage in sports activities to meet their social needs, without the purpose of earning money. Instead, sports is a professional business, the purpose of which is first and foremost to obtain economic benefits. According to the terminology of the current Law of Ukraine "On Physical Culture and Sports" of December 24, 1993, the activity of subjects of the field of physical culture and sport is recognized as a sport, aimed at identifying and unifying the achievements of people in physical, intellectual and other fitness through sports competitions. and appropriate training for them.

Forms of sports activities, as such, can be varied: from sports games of "backyard" teams of children to sports competitions organized by the leading world sports leagues and the Olympic Games.

In addition to amateur and professional sports, the current legislation of Ukraine distinguishes children's sports, child-youth sports, reserve sports, sports of high achievements, sports of veterans, Olympic sports, non-Olympic sports, service-applied and military-applied sports, sports of persons with disabilities.

The list of sports directions stipulated by law is not exhaustive. In particular, some researchers also highlight mass, wellness, competitive, entertainment, "sport for all", organized, semiprofessional, professional-commercial, folk sports, big sports and more.

\section{До питання про визначення поняття "спорт" за законодавством України}

Ткалич М. О.

Запорізький національний університет, вул. Жуковського, 66, Запоріжжя, Украӥна maxx.tkalich@gmail.com

\section{Ключові слова:}

спорт, професійний спорт, спортивне право, любительський спорт, Lex sportiva.
Протягом всього періоду розвитку людської цивілізації спорт відігравав і продовжує відігравати дуже важливу роль. Перші комплекси фізичних вправ та прості ігри виникли вже у первісному суспільстві. Таким чином передавалися навички трудової діяльності, здійснювалася підготовка до військових протистоянь, відправлялися релігійні обряди тощо.

Сучасний спорт $є$ унікальним явищем, яке виконує безліч різноманітних функцій, серед яких варто назвати соціальну, виховну, культурну, економічну, політичну тощо.

Зокрема, сам термін «спорт» (від англ. «disport» або франц. «desport») означає «відпочинок від праці», «розвага». Отже, спорт у новий час виник, передовсім, як спосіб організації дозвілля представників аристократичних кіл європейського суспільства. Цей процес розпочався приблизно у середині 
XVIII століття. Проте невдовзі, з появою середнього класу, що формується 3 початком промислової революції, спорт все більше використовують, як спосіб заробляння коштів: спортсмени отримують гонорари за виступи, а глядачі беруть участь в організації парі - грошових ставок на певний результат спортивних змагань. 3 плином часу обидва зазначені напрямки спорту сформувалися у спорт аматорський (любительський) i спорт професійний. Спортсмени-аматори займаються спортивною діяльністю для задоволення своїх соціальних потреб, без мети заробляння коштів. Натомість спорт професійний є підприємницькою діяльністю, метою якої $\epsilon$ передовсім отримання економічної вигоди.

Відповідно до термінології чинного Закону України «Про фізичну культуру i спорт» від 24.12.1993 p. спортом визнається діяльність суб'єктів сфери фізичної культури i спорту, спрямована на виявлення та уніфіковане порівняння досягнень людей у фізичній, інтелектуальній та іншій підготовленостях шляхом проведення спортивних змагань та відповідної підготовки до них.

Форми здійснення спортивної діяльності, як такої, можуть бути найрізноманітнішими: від спортивних ігор «дворових» команд дітлахів до спортивних змагань, організованих провідними світовими спортивними лігами і Олімпійських ігор.

Крім аматорського і професійного спорту чинне законодавство України виокремлює дитячий спорт, дитячо-юнацький спорт, резервний спорт, спорт вищих досягнень, спорт ветеранів, олімпійський спорт, неолімпійський спорт, службовоприкладний та військово-прикладний спорт, спорт осіб 3 інвалідністю.

Перелік напрямків спорту, закріплений законом, не $\epsilon$ вичерпним. Зокрема, деякі дослідники виділяють також масовий, оздоровчий, змагальний, видовищний спорт, «спорт для всіх», організований, полупрофесійний, професійнокомерційний, народний спорт, великий спорт тощо.

Throughout the development of human civilization, the sport has played and continues to play an important role. The first complexes of physical exercises and simple games have arisen already in the primitive society. In this way skills of work were transferred, preparation for military confrontations was carried out, religious ceremonies were sent, etc.

Modern sport is a unique phenomenon that performs many different functions, including social, educational, cultural, economic, political, etc.

The term "sport" (from the English "disport" or French "desport") [1, 2] means "rest from work", "entertainment". Thus, the sport has emerged in recent times, primarily as a way of organizing leisure for the aristocratic circles of European society. This process began around the middle of the eighteenth century. However, soon with the advent of the middle class, formed with the onset of the Industrial Revolution, sports are increasingly used as a way of earning money: athletes receive performance fees and spectators participate in the organization of money - betting on the outcome of sports events. Over time, both of these areas of sports have evolved into amateur (amateur) and professional sports. Amateur athletes engage in sports activities to meet their social needs, without the purpose of earning money. Instead, sports is a professional business, the purpose of which is first and foremost to obtain economic benefits. 
According to the terminology of the current Law of Ukraine "On Physical Culture and Sport" [3] of December 24, 1993, sport is recognized as an activity of subjects of the field of physical culture and sport, aimed at identifying and unifying the achievements of people in physical, intellectual and other skills through sports competitions and appropriate training for them.

Forms of sports activities can be varied: from sports games of "backyard" teams of children to sports competitions organized by the leading world sports leagues and the Olympic Games.

In addition to amateur and professional sports, the current legislation of Ukraine distinguishes children's sports, child-youth sports, reserve sports, sports of high achievements, sports of veterans, Olympic sports, non-Olympic sports, labor sport and military sports, sports of persons with disabilities.

The list of sports directions stipulated by law is not exhaustive. In particular, some researchers also highlight mass sports, wellness sports, competitive sports, entertainment sports, "sports for all", organized sports, semi-professional sports, professional-commercial sports, folk sports, big sports etc.

So, sports is divided into two main areas: professional and amateur.

According to the Law of Ukraine "On Physical Culture and Sports" (2019) professional sport is a commercial area of activity in sport, connected with the preparation and holding of spectacular sports events at a high organizational level for profit.

The characteristic features of professional sports that distinguish it from amateur and other sports are:

activities;

- commercial nature of sports

- special legal and quasi-legal (local) regulation;

- creating a system of competitions aimed at ensuring the entertainment of sporting events and using the achieved sportsmanship for economic effect;

- stimulating the development of the "sports market" (a branch of the national and international economy, which is the subject of sports goods and services of various entities);

organizational, logistical, economic, political assistance to the development of the most profitable sports.

Amateur sport is a direction in sport; sports activities aimed at addressing a variety of needs, primarily individuals, and are not associated with economic benefits. The main function of amateur sports is the physical and spiritual development, improvement of physical and mental skills and abilities of athletes, enjoyment of sports activities.

Amateur sports activities, in contrast to professional sports, are funded by the athletes themselves and/or the athletes' public associations.

Unlike professional sports, where associations of private sports organizations play a key role in organizing the sporting process, sports non-governmental organizations carry out this function in amateur sports.

Historically, amateur sports have been associated with the Olympic movement. In particular, at the First Olympic Congress, held in Paris in 1894, it was determined that only amateurs could participate in the Olympic Games. However, already at the 1st Olympic Games of 1896, problems began to arise with determining the status of athletes and their admission to the competition. Further, during the entire existence of the Olympic Movement, disputes arose between the distinction between amateur and professional sports. The confrontation between professional and amateur sports ended in favor of the first in 1995 when the International Olympic Committee (IOC) lifted all restrictions on the participation of professionals in the Olympic Games. Thus, professional sports became part of the international sports and Olympic movement. 
Today, the line between professional and amateur sport is conditional, because athletes are free to change their status. At the same time, as mentioned above, professional sportsmen can participate in competitions organized by "amateur" organizations.

According to the criterion of inclusion of sport in the program of the Olympic Games sports are Olympic and non-Olympic.

Olympic sport is a field of sports associated with the organization and conduct of sports competitions in Olympic sports and the preparation of athletes for these competitions.

Non-Olympic sport - is a field of sport, related to the organization and holding of sports competitions in non-Olympic sports and the preparation of athletes for these competitions.

The person who revived the Olympic Games and gave them planetary significance was Pierre de Coubertin. He saw in the Olympic Games not only the revival of ancient ideals but also the form and mode of self-expression of a person for whom the main motive of sports activity should be the joy of the harmony of movements, the festivity of competitions. The Olympic sport was regarded as the best means of promoting such universal values as internationalism, healthy lifestyles, overcoming religious, and racial estrangement.

The revival of the Olympic Games led to the emergence of a new socio-cultural phenomenon - "Olympism". "Olympism" is a philosophy of life that elevates and integrates into a harmonious whole the dignity of the body, will, and mind. Combining sport with culture and education, Olympism seeks to create a lifestyle based on the joy of the effort, the educational value of a good example, and respect for common basic ethical principles" [4].

Olympism is based on certain principles formulated by Pierre de Coubertin in the Olympic Charter:
1. Olympism is a philosophy of life that magnifies and integrates into a harmonious whole the qualities of body, will, and mind. By combining sport with culture and education, it seeks to create a lifestyle based on the joy of effort, the educational value of a good example, and respect for universal fundamental ethical principles.

2. The goal of Olympism is to promote the universal promotion of sport in the service of harmonious human development in order to foster a peaceful society that is interested in maintaining human dignity.

3. The Olympic Movement is a concentrated, organized, universal and continuous activity of all persons and organizations that are inspired by the values of Olympism, led by the IOC. This activity covers five continents. The pinnacle of it is the union of athletes around the world at a major sporting event - the Olympic Games. Its symbol is five intertwined rings.

4. Playing sports is one of the human rights. Everyone should have the opportunity to play sports, without discrimination, in the spirit of Olympism, understanding, friendship, solidarity, and fair play. The organization, management, and management of sports should be controlled by independent sports organizations.

5. Any form of discrimination against a country or a person of a racial, religious, political or gender nature is incompatible with the Olympic Movement.

The Olympic Movement is a movement made up of the International Olympic Committee (IOC), national federations, national Olympic committees, organizing committees of the Olympic Games, national associations, clubs, and their members: primarily athletes, referees, coaches and other affiliated with sports personalities.

In addition to professional, amateur and Olympic sports, we will also briefly describe other areas of sports enshrined in the current national legislation. 
Children's sports. Children's sport is an area of sport that provides children with the opportunity to familiarize themselves with sports and to show their abilities for further sports activities.

Public authorities and local selfgovernment bodies create organizational and legal and other conditions for the development of children's sports and provision of primary education for children through sports, by combining the efforts of family, guardians, carers, children's sports schools, and general educational institutions for development mass and high-level sports.

Children's and youth sports. Children's and youth sports are a line of sports that provides for the involvement of children in a particular sport of children's sports to carry out their sports specialization and provide conditions for the transition to reserve sports.

The development of child-youth sports is provided by the subjects of the sphere of physical culture and sports, in particular child-youth sports schools and corresponding sports clubs.

Reserve sports. Reserve sport is a field of sports that provides in the manner established by the central executive body, which provides for the formation of state policy in the field of physical culture and sports, the selection of gifted children and young people for sports, creation of conditions for maximum development of their individual abilities with the aim of achieving high sports results, providing the conditions for the transition to higher sports and replenishing the core of national teams.

The development of reserve sports is provided by the subjects of physical culture and sports, in particular, sports clubs, specialized educational institutions of sports profile, schools of higher sportsmanship, full-time sports teams of reserve sports of the Autonomous Republic of Crimea, regions, cities of Kyiv and Sevastopol, central executive authorities implement state policy in the field of education, physical culture and sports, all-Ukrainian physicalsports associations, sports federations (hereinafter - full-time reserve sports teams), and other subjects in the field of physical culture and sports.

High-level Sports. The High-level Sports is a field of sports that provides for the involvement of reserve sportsmen through further specialization and individualization of their training process in a particular sport for the preparation, and participation in sporting competitions nationwide and internationally.

The development of High-level Sports is provided by national teams and subjects of the physical culture and sports sphere, including Olympic training centers, schools of higher sportsmanship, sports clubs, as well as sports teams of the Armed Forces of Ukraine and other military formations formed in accordance with the laws of Ukraine, law enforcement agencies bodies, rescue, and other special services, as well as subjects of the field of physical culture and sports, which promote the development of professional sports.

Labor sports and military sports. labor sport and military sport is a field of sport, related to the performance of military personnel and employees of the Armed Forces of Ukraine, other military formations formed under the laws of Ukraine, law enforcement agencies, rescue and other special services of their official duties. Labor sports and military sports are provided by the subjects of physical culture and sports.

Disabled sports - a field of sport, related to the organization and conduct of sports competitions in the sports of persons with disabilities and the preparation of athletes for these competitions.

Thus, modern sport is a unique socio-cultural phenomenon that reveals its essence through a variety of directions, forms and ways of performing sports activities.

Concerning the national sports system, its characteristic feature is the combination of two organizational models: market ("Western") and non-market ("Soviet"). It is said that the main driver of 
the development of sports in Western countries is private interest (the sports market), and the main priority of Soviet sports was public interest (mass sports). Accordingly, the main organizational element of the Western (more American and less European) sports system is the private sports club and the association of sports clubs (professional sports leagues). The main actors in domestic sports are state and public (actually quasi-state) organizations. This is primarily about sports federations and sports associations. At the same time, mass sport, like other sports, is now in decline.

However, despite the state's inability to secure normal funding for sport, it nevertheless holds a dominant position in the institutional system of the national sport. This interventionist approach has been preserved since the Soviet era. It should be emphasized that in the difficult economic situation in which our country is permanently in place, and chronic underfunding of sports, it is extremely important to form such an organizational system of sports, in which the professional sport would have a leading place. It is professional sports as a kind of economic activity that can accumulate the funds needed to build not only professional sports but also the whole system of national sports.

\section{References}

1. Definition of "disport", (2019), Collins dictionary, available at: https://www.collinsdictionary.com/dictionary/english/disport.

2. "Sport", (2019), Larousse, available at : https://www.larousse.fr/encyclopedie/divers/sport/93529.

3. "On physical culture and sport" : Law of Ukraine dated 24.12.1993, Vidomosti Verkhovnoi Rady Ukrainy, 1994, no. 14, art. 81.

4. “Olympism and Principles of Olympism”, (2019), Bukvi.ru Popular science portal, available at : http://bukvi.ru/obshestvo/fizkultura/olimpizm-i-principy-olimpizma.html. 


\title{
РОЗДІЛ IV. АДМІНІСТРАТИВНЕ ТА ФІНАНСОВЕ ПРАВО
}

УДК 340.134:3.08:001.893

DOI https://doi.org/10.26661/2616-9444-2019-2-06

\section{Інструментарій «кабінетного дослідження»: чи вдалою с нова законодавча модель моніторингу способу життя?}

\author{
Коломоєць Т. О., Кушнір С. М.
}

Запорізький національний університет, вул. Жуковського, 66, м. Запоріжжся, Украӥна t_deputy@ukr.net

\author{
Ключові слова: \\ моніторинг, спосіб життя, \\ корупиія, "кабінетне \\ дослідження», законодавча \\ модель, інструменти, \\ удосконалення.
}

Надійшло до редколегії: 15.09 .2019

Прийнято до друку: 18.10.2019
У статті порушено питання якості зміни вітчизняної законодавчої моделі «кабінетного дослідження» як складової частини ресурсу моніторингу способу життя публічних службовців як антикорупційного засобу. Звертаючи увагу на важливу роль інструментарію як сукупності засобів, методів, прийомів, за допомогою яких «кабінетне дослідження» здійснюється, порівнюючи його чинну законодавчу модель із раніше діючою, автори формулюють висновок про те, що іiі модифікація $\epsilon$ успішною (як розширено їх кількісний вимір, так і збільшено їх розмаїття, сформовано підстави для практичного використання), що дає змогу зробити припущення про формування достатнього підгрунтя для зростання антикорупційної дієвості моніторингу способу життя публічних службовців в Україні. Водночас порівняння відповідної моделі із зарубіжними аналогами дає змогу сформувати висновок про ії переважно традиційний характер, який відрізняється менш інтрузивними інструментами, отже, менш інноваційними результатами застосування відповідного антикорупційного засобу. Сформовано пропозицію щодо доцільності врахування досвіду зарубіжної тематичної нормотворчості та правозастосування в аспекті модифікації такої моделі саме за рахунок розширення видового розмаїття інтрузивних інструментів та фіксації засад їх використання у базовому вітчизняному антикорупційному законодавчому акті.

\section{Tools set of "desk research": is the new legislative model of lifestyle monitoring model successful?}

Kolomoiets T. O., Kushnir S. M.

Zaporizhzhia National University, 66, Zhukovskyi str., Zaporizhzhia, Ukraine

t_deputy@ukr.net

Key words:

monitoring, lifestyle, corruption, "desk research", legislative model, tools, improvement.
The article considers the issue of quality of the change of the domestic legislative model of "desk research" as an integral part of the resource of lifestyle monitoring of public servants as an anti-corruption means. Drawing attention to the important role of the toolkit as a set of tools, methods, techniques which contribute to the implementation of "desk research" comparing its current legislative model with previous one, the 
authors conclude that its modification is successful (both their quantitative dimension and diversity were expanded, and the grounds for practical use were formed) that allows making an assumption about the formation of relevant basis for improvement of anti-corruption effectiveness of lifestyle monitoring of public servants in Ukraine. At the same time, the comparison of the relevant model with foreign counterparts makes it possible to conclude about its predominantly traditional character which is characterized by less intrusive tools and therefore, less innovative results of the use of the anti-corruption tool. The authors see it expedient to take into account the experience of foreign issue-related rule-making and law enforcement in terms of modification of that kind of model through expanding specific diversity of intrusive instruments and the fixation of the principles of their use in the basic domestic anti-corruption legislative act.

В умовах активного пошуку ефективних засобів запобігання корупції у всіх іiі проявах в Україні, активізації нормотворчої, зокрема законотворчої, діяльності, зорієнтованої на впровадження нових, зокрема запозичених 3 досвіду зарубіжних країн, стандартів використання ресурсу різноманітних антикорупційних засобів, уніфікації антикорупційної практики увага зацікавленої спільноти концентрується на вдосконаленні не тільки моделей антикорупційних засобів та їх законодавчого підгрунтя, але й їх елементів, що дає змогу посилити засади спеціалізації вищезазначеного пошуку, знайти проблемні питання як самого законодавчого підгрунтя, так і практики його застосування, отже, дефекти елементу, що знижує антикорупційну цінність засобу загалом.

Вирішення цього питання дасть змогу запропонувати конкретні варіанти вирішення інших проблем, насамперед проблем щодо інструментарію, активізації законотворчості, визначення шляхів оптимізації та уніфікації цільового правозастосування, ефективного запобігання корупції в усіх іiі проявах. Втім, дещо поверховий, спрощений підхід до вирішення відповідних питань, незважаючи на витрачені зусилля та наявні результати (зміна законодавчої моделі, рекомендації щодо уніфікації правозастосування), не здатний запропонувати досконалий за змістом та ефективний у застосуванні варіант вирішення відповідних питань, отже, ефективне запобігання корупції.

Важливим $\epsilon$ врахування витрат часу, кадрових та інших ресурсів для пошуку відповідного рішення й формування підстав для його ефективного втілення у життя. За умови наявності такого варіанта можна з'ясувати його дієвість, ефективність або навпаки, отже, відповісти на запитання щодо доцільності витрати часу та ресурсів. Наприклад, можна зосередити увагу на новій законодавчій моделі обов'язкової складової моніторингу способу життя публічних службовців, а саме «кабінетного дослідження» (зокрема, іii інструментарію), запропонованій у зв'язку зі внесенням змін до законодавчих актів щодо ефективності інституційного механізму запобігання корупції Законом України від 2 жовтня 2019 року, з огляду на те, що роль і значення відповідного антикорупційного засобу постійно зростає, а вдосконалення його законодавчої моделі, зокрема всіх іiі складових, апріорі зорієнтоване на подальше «домінування» його в системі антикорупційних засобів. Втім, варто все ж таки з'ясувати, чи дійсно нова законодавча модель інструментарію відповідного засобу та всіх його складових істотно модифікувалася порівняно 3 раніше діючою та $\epsilon$ оптимальною для реальних умов запобігання корупції, чи дефекти законодавчого підгрунтя для використання цього засобу залишилися, а 
витрачені ресурси часу, кадрів, зусилля були марними. Все це обумовлює формулювання мети роботи, яка полягає у 3'ясуванні на підставі аналізу положень новітнього національного, насамперед «базового антикорупційного», законодавства ступеня відповідності запропонованої моделі інструментарію «кабінетного дослідження» реальним вимогам антикорупційного правозастосування.

Дослідження грунтується на поєднанні загальнонаукових та спеціальних методів наукового пізнання. Базуючись на засадах діалектичного аналізу, що дало змогу виявити якісні зміни у вітчизняному законодавчому підгрунті інструментарію «кабінетного дослідження», використовуємо порівняльно-правовий метод для з'ясування ступеня модифікації відповідного підгрунтя, а також його відповідності зарубіжним аналогам. За допомогою методів прогнозування та моделювання сформульовано пропозиції щодо забезпечення останнього.

Аналіз наявних тематичних джерел свідчить про те, що увага зацікавленої фахової наукової спільноти переважно концентрується або на узагальненому висвітленні ресурсу моніторингу способу життя як антикорупційного засобу [1], або особливостях його застосування в практиці зарубіжних країн [2], або висвітленні проблем у застосуванні, щоправда, без виокремлення елементів механізму відповідного засобу [3], або на різних елементах останнього, щоправда, переважно не на інструментарії його двох «базових складових» [4]. Втім, незважаючи на наявність відповідних джерел, варто звернути увагу на те, що прогалиною $\epsilon$ залишення поза увагою як нової законодавчої моделі цього засобу загалом, так i окремих іiі елементів, зумовлених результатами новітньої законотворчості, зорієнтованої на вдосконалення ефективності інституційного механізму забезпечення запобігання корупції.

\section{I. «Кабінетне дослідження» - невід'смна складова моніторингу способу життя як антикорупційного засобу.}

Ресурс моніторингу способу життя як антикорупційного засобу формується за рахунок поєднання двох його складових, а саме «кабінетного дослідження» та «польового дослідження». Якщо перша складова безпосередньо зорієнтована на оброблення відповідностей, які сконцентровані в різних паперових та інформаційних носіях, та передбачає роботу з документами, звідки випливає іiі інша назва, а саме «документальне дослідження», або оброблення відповідних документів без будь-яких додаткових дій поза місцем роботи суб'єкта («кабінетне дослідження», «кабінетна робота») [1, с. 9], то друга складова пов'язана 3 візуальним ознайомленням із поведінкою особи, щодо якої моніторинг здійснюється, iï майном, ii хобі тощо. Друга складова моніторингу способу життя передбачає активність суб'єкта його здійснення переважно поза місцем своєї роботи, дії поза межами робочого місця, зовнішню діяльність, «дослідження у полі». Як наслідок, існує розмаїття іiі назв, а саме «польове дослідження», «візуальне спостереження», «спостереження на місці» [5, с. 165]. Отже, вищезазначене дає змогу стверджувати, що «кабінетне дослідження» як складова загального ресурсу моніторингу способу життя як антикорупційного засобу безпосередньо пов'язане з обліком, аналізом відомостей щодо надходжень, доходів, отриманих публічним службовцем та членами його сім'ї, їх майном, а також із відомостями стосовно витрат на стиль їхнього життя задля встановлення їх відповідності або невідповідності. Саме специфіка «кабінетного дослідження» обумовлює його безпосередній зв'язок із базами інформаційних даних, державними та альтернативними реєстрами, іншими інформаційними ресурсами, отже, вимагає 
задля своєї результативності допуск, доступ до них, усунення перешкод та «фільтрів». Отже, результативність «кабінетного дослідження» як складової антикорупційного засобу фактично залежить від законодавчого закріплення можливості суб'єкта здійснення моніторингу способу життя доступу до наявних інформаційних ресурсів, «актуального стану» останніх та гарантування отримання таких даних, зокрема за рахунок закріплення обов'язку ïх утримувачів, відповідальних за збереження, наповнення та оброблення, надавати таку інформацію за запитом суб'єкта здійснення відповідного моніторингу разом зі впровадженням та розширенням практики створення альтернативних реєстрів, баз даних, інформаційних систем [6].

II. Інструментарій «кабінетного дослідження»: чи вдалося усунути дефекти законодавчої моделі?

За наявності окремої статті у базовому антикорупційному законодавчому акті, який закріплює засади використання ресурсу моніторингу способу життя як антикорупційного засобу (ст. 51 Закону України «Про запобігання корупції»), зокрема за рахунок його обов'язкової складової, якою $\epsilon$ «кабінетне дослідження», вже неодноразово зазначалося, що дефектним $\epsilon$ саме інструментарій здійснення останнього. Отже, наділяючи НАЗК відповідним функціональним призначенням, законодавець, на жаль, спрощено підійшов до законодавчого закріплення забезпечення його доступу до відповідних інформаційних ресурсів, фактично унеможливлюючи результативність здійснення відповідного антикорупційного засобу [3, с. 408].

Дефективність інструментарію «кабінетного дослідження» негативно впливала на результат використання ресурсу моніторингу способу життя загалом, об'єктивно зумовлюючи нагальну потребу модифікації законодавчої моделі відповідного інструментарію в контексті вирішення проблеми забезпечення ефективності інституційного механізму запобігання корупції. Законом України «Про внесення змін до деяких законодавчих актів України щодо забезпечення ефективності інституційного механізму запобігання корупції» від 2 жовтня 2019 року відповідну модель інструментарію «кабінетного дослідження» модифіковано. Отже, розширено можливості безпосереднього автоматизованого доступу до інформаційнотелекомунікаційних і довідкових систем, банків даних, реєстрів, зокрема тих, які містять відомості з обмеженим доступом, адміністратором яких є держава в особі органів державної влади або органів місцевого самоврядування; доступу до державних, зокрема урядових, засобів комунікації та зв'язку, мереж спеціального зв'язку тощо; доступу до інформації Єдиного реєстру досудових розслідувань у порядку, регламентованому вимогами чинного законодавства; доступу до інформації у відкритих баз даних, реєстрів іноземних держав, зокрема за умови платного доступу; закріплено зобов'язання осіб, уповноважених на виконання функцій держави або місцевого самоврядування, суб'єктів господарювання, приватних осіб надавати запитувану НАЗК інформацію та документи, зокрема 3 обмеженим доступом (ст. 12 Закону України «Про запобігання корупції» 3 урахуванням змін). Безперечно, розширення інструментарію істотно впливає на антикорупційну дієвість як «кабінетного дослідження» зокрема, так і моніторингу способу життя загалом, що дає змогу позитивно оцінити законодавчі зміни, які фактично усунули будь-які перешкоди для активної діяльності моносуб'єкта здійснення моніторингу способу життя як антикорупційного засобу. Втім, аналіз зарубіжного законодавства щодо регламентації засад інструментарію «кабінетного дослідження» свідчить про можливість впровадження інших, більш 
інтрузивних інструментів, а також про сформовану позитивну практику їx активного використання.

Так, наприклад, у законодавстві Словенії, окрім доступу до різноманітних інформаційно-довідкових ресурсів, суб'єкт здійснення моніторингу способу життя має можливість у разі неотримання від публічного службовця пояснень стосовно відповідності даних щодо доходів та видатків на стиль свого життя або своїх родичів (слід звернути увагу на дещо розширене коло «сторонніх осіб» порівняно 3 новітніми змінами у базовому вітчизняному антикорупційному законодавчому акті) запропонувати органу, в якому цей службовець працює, знизити заробітну плату на десять відсотків, а також почати дисциплінарне провадження стосовно звільнення цієї особи, як, до речі, й публічно розголосити відомості про певні порушення особи, зокрема у 3MI, посиливши інформаційний аспект запобіжника корупції щодо розширення спектру реалізації відповідної функції. У Македонії впроваджено практику ведення реєстрів доходів та витрат публічних службовців тими органами, в яких такі службовці працюють, обов'язок надавати доступ до таких реєстрів у разі здійснення моніторингу способу життя будь-якого співробітника, а також «перехресний» доступ під час моніторингу способу життя до реєстрів за місцем служби особи та податкового органу (формується за підсумками подання декларацій). Аналогічною $\epsilon$ законодавча модель інструментарію «кабінетного дослідження» як складової моніторингу способу життя у Румунії та Латвії, щоправда, дещо розширеним $\epsilon$ коло «сторонніх осіб», що дає змогу виявити опосередковані зв'язки публічного службовця [7, с. 5]. У США додатково впроваджено практику запиту додаткової інформації як у самого службовця, так і у членів його родини (наприклад, для службовців Білого Дому існує перелік такої інформації з іiі розподілом на умовні три блоки, такі як майнова будь-яка, інформація про кредитні зобов'язання, інформація про нерухому власність), а також можливість проведення перевірки на поліграфі. У законодавстві Бразилії поширеним $\epsilon$ залучення громадськості до здійснення відповідного антикорупційного засобу [2, с. 183], 3МI, що істотно розширює можливості для встановлення відповідності або невідповідності даних про доходи та стиль життя публічних службовців та членів їх сімей. Залучення громадськості зумовлює розмаїття інструментів «кабінетного дослідження». Як наслідок, істотно зростає роль останнього у ресурсі моніторингу способу життя як антикорупційного засобу [8].

Незважаючи на активну антикорупційну практику громадськості в Україні, наявність альтернативних інформаційних ресурсів та обгрунтування потреби залучення цього суб'єкта до відповідної діяльності [6, с. 18; 9, с. 377], весь інструментарій «кабінетного дослідження», запропонований у новій вітчизняній законодавчій моделі, виглядає розширеним і дієвим порівняно з раніше визначеним. Проте його аналіз дає змогу говорити про його переважно традиційний характер (запит, доступ, прохання надати пояснення, співставлення або порівняння тощо), хоча, як засвідчує позитивна апробована часом практика зарубіжних країн, цілком можливим $\epsilon$ впровадження більш інтрузивних інструментів, які одночасно були б зорієнтовані не тільки на 3'ясування відповідності (невідповідності) певних даних щодо доходів та витрат публічних службовців, але й на попередження, можливо, й припинення можливих протиправних діянь останніх, що суттєво посилило би дієвість моніторингу способу життя саме як антикорупційного засобу.

Отже, запропонована в контексті пошуку оптимальних шляхів підвищення ефективності інституційного механізму запобігання корупції в Україні новітня 
законодавча модель інструментарію «кабінетного дослідження» як складової моніторингу способу життя як антикорупційного засобу, безперечно, виглядає дієвою, досконалою, передбачає його видове розмаїття та передумови практичного використання. Це порівняно 3 раніше визначеним аналогом, слугуватиме підставою для істотної активізації використання відповідного антикорупційного засобу, його результативності. Проте задля досягнення максимально ефективного результату, аналогічного зарубіжним варіантам, доцільним все ж таки вбачається його доповнення більш інтрузивними інструментами, які би були зорієнтовані на реалізацію поліваріативного функціонального призначення, а також об'єктивно посилювали антикорупційну дієвість як самого «кабінетного дослідження», так і моніторингу способу життя загалом.

\section{Література}

1. Моніторинг способу життя: огляд міжнародної практики, можливість застосування в Україні. Київ : Програма розвитку ООН в Україні, 2016. 36 с.

2. Васильева В. Регулирование конфликта интересов на государственной службе: Бразильский опит (часть 2). Bonросы государственного и муниципального управления. 2015. № 3. С. 165-190.

3. Науково-практичний коментар Закону України «Про запобігання корупції» / за заг. ред. Т. Коломоєць, В. Колпакова. Запоріжжя : Видавничий дім «Гельветика», 2019. $588 \mathrm{c}$.

4. Коломоєць Т., Кушнір С. Пропорційність як нормативно-закріплений «фільтр» використання ресурсу моніторингу способу життя. Актуальні проблеми вітчизняної юриспрудениії. 2019. № 4. С. 152-157.

5. Коломоєць Т. Моніторинг способу життя осіб, уповноважених на виконання функцій держави або місцевого самоврядування: пошук «новаційних» інструментів реалізації законодавчої моделі. Юридичний бюлетень. 2019. Вип. 9. С. 164-170.

6. Бесшерстна О. Десять інструментів для інноваційної боротьби 3 корупцією. Юридичний вісник Украӥни. 2019. № 34-35 (1259-1260). С. 18.

7. Яременко С., Яременко О. Сторінка антикорупціонера. Запобігання та врегулювання конфлікту інтересів: досвід Латвії. Держслужбовещъь. 2019. № 5. С. 3-5.

8. Сердюк В. Політ у відставку: як гучний корупційний скандал вплине на політичні розклади в Польщі? Юридичний вісник Украӥни. 2019. № 34-35 (1259-1260). С. 13.

9. Kolomoiets T., Kolpakov V. Lifastyle monitoring as an anti-corruption means under the legislation of Ukraine: "has it passed the proportionality test"? The instituonalisation of public relations in the fight against corruption: the experience of countries of Eastern and Western legal traditions (universal theoretical framework for relevant anti-corruption law in Ukraine) : collective monograph. Vol. I. Tallinn : Isdernieciba "Baltija Publishing", 2019. P. 321-338.

\section{References}

1. (2016), Monitorynh sposobu zhyttia: ohliad mizhnarodnoi praktyky, mozhlyvist zastosuvannia $v$ Ukraini [Lifestyle monitoring: review of international practice, applicability in Ukraine], Prohrama rozvytku OON v Ukraini, Kyiv, Ukraine. 
2. Vasyleva, V. (2015), "Regulation of a conflict of interest at the civil service: Brazilian experience (part 2)", Voprosy hosudarstvennoho i municipalnoho upravleniya, no. 3, pp. $165-190$.

3. Kolomoiets, T., Kolpakov, V. et al. (2019), Naukovo-praktychnyi komentar Zakonu Ukrainy "Pro zapobihannia koruptsii" [Scientific practical commentary on the Law of Ukraine "On Prevention of Corruption"], Vydavnychyi dim "Helvetyka", Zaporizhzhia, Ukraine.

4. Kolomoiets, T., and Kushnir, S. (2019), "Proportionality as a statutory "filter" for the use of lifestyle monitoring resource", Aktualni problemy vitchyznianoi yurysprudentsii, no. 4, pp. 152-157.

5. Kolomoiets, T. (2019), "Monitoring of lifestyle of people empowered to perform the functions of the state or local government: a search for "innovative" tools for the implementation of a legislative model", Yurydychnyi biuleten, Iss. 9, pp. 164-170.

6. Bessherstna, O. (2019), "Ten tools for innovative fight against corruption", Yurydychnyi visnyk Ukrainy, no. 34-35 (1259-1260), August 23 - September 5, 2019, p. 18.

7. Yaremenko, S. and Yaremenko, O. (2019), "Anti-corruption crusader column. Prevention and regulation of the conflict of interests: an experience of Latvia", Derzhsluzhbovets, no. 5, pp. 3-5.

8. Serdiuk V. (2019), "Retired fly: how does a high-profile scandal influence political scenario in Poland?", Yurydychnyi visnyk Ukrainy, no. 34-35 (1259-1260), August 23 September 5, 2019, p. 13.

9. Kolomoiets, T. and Kolpakov, V. (2019), Lifestyle monitoring as an anti-corruption means under the legislation of Ukraine: "has it passed the proportionality test"? The instituonalisation of public relations in the fight against corruption: the experience of countries of Eastern and Western legal traditions (universal theoretical framework for relevant anti-corruption law in Ukraine) : collective monograph. Vol. I. Tallinn: Isdernieciba "Baltija Publishing", pp. 321-338.

УДК 343.102:351.746.2(477)

DOI https://doi.org/10.26661/2616-9444-2019-2-07

\section{Набуття права на приватну детективну (розшукову) діяльність в Україні: деякі дискусійні питання перспективної регламентації}

\section{Пирожкова Ю. В.}

Запорізький національний університет, вул. Жуковського, 66, м. Запоріжжся, Украӥна pyrozhkovaznu@gmail.com

\begin{tabular}{|c|c|}
\hline $\begin{array}{l}\text { і слова: } \\
\text { оронні } \\
\text { ий } \\
\text { ивні пос. } \\
\text { ивна } \\
\text { ть, пропо }\end{array}$ & $\begin{array}{l}\text { У статті проаналізовано поло } \\
\text {, законопроєктів, у яких зроблено } \\
\text { професійну детективну діяльність. Ал } \\
\text { підходи законодавця до визначення вим } \\
\text { на приватну детективну діяльність, } \\
\text { базових підходів до можливих стан }\end{array}$ \\
\hline
\end{tabular}


Надійшло до редколегії:

09.09.2019

Прийнято до друку: 13.10.2019. відповідати кандидат. Задля вдосконалення наявних законопроєктів, які закладають основи створення необхідних умов в Україні для приватної детективної (розшукової) діяльності з огляду на специфіку недержавної правоохоронної діяльності, виокремлено дискусійні питання перспективної регламентації набуття права на професійну детективну діяльність в Україні, які потребують перегляду.

\title{
Acquisition of the right to private detective (search) practice in Ukraine: some discussions on perspective regulation
}

\section{Pyrozhkova J. V.}

\author{
Zaporizhzhya National University, Zhukovsky st., 66, Zaporizhzhia, Ukraine \\ pyrozhkovaznu@gmail.com
}

Key words:

At the present stage of development, states have accumulated law enforcement, private detective, considerable practice of outsourcing part of their traditionally detective services, private detective monopolized functions, as evidenced by the legalization of the (search) practice, offers. activities of private security firms providing protection for individuals, movable and immovable property. Or to give another example, due to the transition to a combined (mixed) enforcement system, resulting in a new legal institute for private enforcement in our country, which has been operating effectively in Belgium, the United Kingdom, Luxembourg, France, the Netherlands, France and other country, in Ukraine it is at the stage of formation. Other civil society institutions can also provide the necessary resource to counteract unlawful encroachment at the expense of the state's prudent approach to the functioning of non-state institutions, which can compensate for the shortcomings of the state law enforcement system in crime prevention and investigation.

The relevance of the study of existing attempts to legalize private detective (search) practice in Ukraine, as well as the analysis of the requirements governing the acquisition of the right to professional private activity is conditioned by real practical needs and is quite obvious, since the services of private detectives are used throughout the civilized world regulated by law and optimally used to empower citizens and legal entities to protect their legal rights and interests and, in the UK, Spain, Italy, India, Israel, Canada, Mexico, Germany, Norway, Portugal, Russian Federation, United States, France, Japan and many other countries. At the same time, there is still no relevant legislation in Ukraine regulating the activity of private detectives, creating a proper foundation for the civilized market for detective services, although the issue has been under discussion in national legal science for quite some time.

The article analyses the provisions of the domestic draft laws in which an attempt was made to normalize professional detective activity. The author draws attention to the legislator's approaches to determining the requirements for acquiring the right to private detective activity, outlines several basic approaches to the possible standards, which the candidate must meet. In order to improve the existing bills that lay the foundations for creating the necessary conditions in Ukraine for private detective (investigative) activity, taking into account the specifics of non-state law enforcement 
activity, the discussion issues of the prospective regulation of the acquisition of the right to professional detective practice in Ukraine are highlighted.

The author concludes that despite the large number of bills on the legalization of private detective activity, there is a tendency to fixation the requirements for applicants for private detective practice. At the same time, all the above proposals contain a number of fundamentally different approaches to establishing the requirements for the specialty and educational qualification of the persons concerned. It should be noted that the statutory determination of the period of validity of the certificate of special training by a candidate for detectives and the term that has expired since the termination of service in operational units or bodies of pre-trial investigation have generally remained out of the legislator's attention. Taken together, all of the above necessitates a prudent approach by the legislator to regulate the legal bases of acquiring the right to professional private detective (search) practice in Ukraine.

Пережиті сучасним суспільством зміни в політико-правовій системі обумовили прийняття Стратегії сталого розвитку «Україна - 2020», у якій задля подальшого руху до Європейського Союзу окреслено першочергові пріоритети та індикатори належних оборонних, соціально-економічних, організаційних, політико-правових умов становлення та розвитку України. Одним iз базових напрямів подальших державних перетворень $є$ вектор відповідальності, реалізація якого передбачає здійснення цілої низки реформ. Правоохоронна система не стала винятком, оскільки підвищення рівня захисту прав і свобод людини, а також інтересів суспільства й держави від протиправних посягань $\epsilon$ можливим лише завдяки іiі функціональним та організаційним перетворенням, спрямованим на коригування завдань та функцій правоохоронних органів, упровадження нових засад проходження служби, відпрацювання нових критеріїв оцінювання роботи правоохоронців для підвищення рівня захисту прав і свобод людини, а також інтересів суспільства й держави від протиправних посягань.

$$
\text { Правоохоронні органи }
$$
ключовими в системі органів виконавчої влади, їх стабільне та ефективне функціонування $\epsilon$ необхідною умовою захисту конституційного ладу, забезпечення законності й правопорядку, дотримання прав і свобод людини та громадянина. Від ефективності діяльності правоохоронних органів значною мірою залежать успішність реалізації національних інтересів та стабільність суспільного розвитку. При цьому правове визначення поняття й системи правоохоронних органів досі відсутнє. Більш того, на сторінках наукових та професійних видань під час проведення науково-практичних конференцій, круглих столів за участю політиків, науковців та фахівців сьогодні широко обговорюється питання прийнятності та доцільності поєднання державної та недержавної правоохоронної діяльності, оскільки, як цілком справедливо зазначає С. Юрко, правоохоронні органи 3 об'єктивних та суб'єктивних причин (обмеженість державного бюджету, недовіра громадян, корупція, перевантаженість роботою) не завжди можуть забезпечити повну безпеку суспільства від протиправних загроз [1].

На сучасному етапі розвитку державами накопичено чималу практику аутсорсингу частини своїх традиційно монополізованих функцій, про що свідчить легалізація діяльності приватних 
охоронних фірм, що здійснюють охорону фізичних осіб, рухомого та нерухомого майна. Наведемо також інший приклад, обумовлений переходом до комбінованої (змішаної) системи виконавчого провадження, внаслідок чого з'явився новий для нашої держави правовий інститут приватних виконавців, який вже досить тривалий проміжок часу ефективно працює у Бельгії, Великобританії, Люксембурзі, Нідерландах, Франції тощо, а в Україні перебуває на стадії становлення.

Необхідний ресурс для протидії протиправним посяганням можуть надати інші інститути громадянського суспільства за рахунок виваженого підходу держави до функціонування недержавних інституцій, спроможних компенсувати недоліки державної правоохоронної системи щодо попередження та розслідування злочинів. Цей процес помітний у законодавстві та практиці багатьох країн, де стимулюється та заохочується розвиток приватних детективних агентств, зокрема охоронних фірм, служб безпеки та різних громадських правоохоронних формувань (в Англії, наприклад, кількість персоналу приватних охоронних та детективних фірм вдвічі перевищує кількість співробітників поліції; у США приватні служби безпеки мають бюджет, який на $50 \%$ перевищує бюджет усіх органів поліції країни разом узятих, нараховуючи понад 1,1 млн. співробітників; в Ізраїлі (3 населенням трохи більше 5 млн.) функціонує понад дві тисячі детективних та охоронних компаній $[2$, с. 1]).

Отже, актуальність дослідження наявних спроб легалізації приватної детективної (розшукової) діяльності в Україні, а також аналіз вимог, що регулюють набуття права на професійну приватну діяльність, обумовлюється реальними практичними потребами та $є$ цілком очевидною, оскільки послугами приватних детективів користуються в усьому цивілізованому світі, а приватна детективна діяльність врегульована законами та оптимально використовується для збільшення можливості громадян та юридичних осіб щодо захисту своїх законних прав та інтересів, зокрема, у Великобританії, Іспанії, Італії, Індії, Ізраїлі, Канаді, Мексиці, Німеччині, Норвегії, Португалії, Російській Федерації, Сполучених Штатах Америки, Франції, Японії. Хоча в Україні де-юре приватної детективної діяльності не існує, де-факто, згідно з даними Всеукраїнської асоціації приватних детективів (ВАПД), реєстр членів Асоціації містить понад 30 детективних агентств [3], діяльність яких спрямована на пошук, збирання та фіксацію інформації, розшук предметів, майна й безвісти зниклих людей, попередження, виявлення фактів та обставин розголошення відомостей, що становлять комерційну таємницю, встановлення авторів та відправників анонімних листів, поширювачів відомостей, що ганьблять окремих осіб. Водночас сьогодні в Україні відсутнє відповідне законодавство, яке б регулювало діяльність приватних детективів, створюючи відповідний фундамент для цивілізованого ринку детективних послуг, хоча навколо цього питання у вітчизняній правовій науці дискусія точиться вже протягом досить тривалого часу.

Відразу варто зазначити, що проблематика приватної детективної (розшукової) діяльності як додаткового ефективного інструменту в боротьбі зі злочинністю та правопорушеннями, забезпеченні захисту прав i свобод людини й громадянина привертала увагу вчених-юристів, про що свідчить кількість робіт (наприклад, праці Н. Ахтирської, В. Білоуса, В. Веденської, А. Зайця, С. Краснокутського, $\quad$ В. Литвиненко, О. Музичука, Д. Мулявки, В. Олефіра, О. Пунди, О. Рябченко, А. Старушкевича, I. Хорта, О. Шелухіна, С. Юрко, О. Ярмиша), проте питання правового регулювання набуття права на професійну приватну детективну діяльність $\epsilon$ недостатньо дослідженими в сучасній 
правовій науці. Отже, досі (тим більше в аспекті подання чергового Законопроєкту «Про приватну детективну (розшукову) діяльність» від 8 лютого 2019 р. № 10024, метою якого є законодавче врегулювання організації приватної детективної (розшукової) діяльності в Україні як одного зі шляхів забезпечення конституційних гарантій людини та громадянина на захист своїх законних прав та інтересів) пропозиції щодо врегулювання питання набуття права на професійну приватну детективну (розшукову) діяльність в Україні залишаються недосконалими, потребують доопрацювання та коригування як в аспекті освітньо-фахових вимог до претендентів на здійснення детективної діяльності, так і механізму підтвердження відповідності ним як необхідної умови допуску до професійної діяльності.

Отже, враховуючи кількість законопроєктів, у яких було зроблено спробу унормувати професійну детективну діяльність, перш за все зупинимось на аналізі вже запропонованих дефініцій стосовно набуття права на професійну детективну (розшукову) діяльність та вимог до суб'єктів такої діяльності. Так, у проєкті Закону України «Про приватну детективну діяльність» від 7 квітня 2004 р. № 5380 [4] до претендентів на отримання ліцензії на право здійснення приватної детективної діяльності пропонувалося встановити такі вимоги: наявність повної вищої юридичної освіти, стажу роботи не менше п'яти років на посадах дізнавачів, слідчих суддів, прокурорів, помічників прокурорів, помічників приватних детективів та працівників, які здійснювали оперативнорозшукову діяльність, працюючи в органах та підрозділах Міністерства внутрішніх справ України, Державної прикордонної служби України, Служби Безпеки України, управлінні охорони вищих посадових осіб. При цьому у висновку Головного науково-експертного управління від 19 травня 2004 р. щодо зазначеного Законопроєкту вимога щодо наявності базової вищої юридичної освіти була визнана необгрунтованою, а також зауважено (на нашу думку, не зовсім вдало 3 огляду на специфіку детективної (розшукової) діяльності), що для професії приватного детектива краще мати освіту у галузі комп'ютерної техніки, соціології, журналістики тощо.

Альтернативний Законопроєкт від 1 липня 2004 р. № 5380-1 взагалі не містив вимог до осіб щодо набуття права на професійну приватну діяльність, а проєкт Закону України «Про приватну детективну (розшукову) діяльність» від 12 квітня 2010 р. № 6288, навпаки, суттєво розширив вимоги до претендентів на зайняття приватною детективною діяльністю, оскільки в ньому було запропоновано приватним детективом визнавати громадянина України, який досяг двадцяти одного року, має вищу юридичну чи спеціальну освіту, не перебуває на обліку в органах охорони здоров'я у зв'язку з психічним захворюванням, алкоголізмом чи наркоманією, не має судимості та отримав у встановленому порядку свідоцтво про право на заняття приватною детективною (розшуковою) діяльністю [5]. Законопроєктом від 13 грудня 2012 р. № 1093 передбачалося, що приватним детективом може бути громадянин України, який досяг двадцяти одного року, має вищу юридичну чи спеціальну освіту або пройшов спеціальну підготовку для заняття приватною детективною (розшуковою) діяльністю чи має стаж роботи в оперативних або слідчих підрозділах не менше трьох років, не перебуває на обліку в органах охорони здоров'я $\quad$ у зв'язку 3 психічним захворюванням, алкоголізмом чи наркоманією, не має судимості та отримав у встановленому порядку свідоцтво про право на заняття приватною детективною (розшуковою) діяльністю [6].

Аналогічний підхід було збережено в проєкті Закону України «Про приватну детективну (розшукову) діяльність» від 28 
грудня 2015 р. № 3726 [7], у якому серед вимог до претендентів на зайняття приватною детективною діяльністю залишилися всі вищезазначені щодо громадянства, освіти, стажу роботи в оперативних підрозділах чи органах досудового розслідування, при цьому законодавець вперше до переліку вимог додав володіння державною мовою та допустив як альтернативу наявність у особи, що претендує займатися приватною детективною діяльністю, вищої юридичної освіти або стажу роботи в оперативних підрозділах чи органах досудового розслідування не менше трьох років. Окрім того, серед основних вимог до кандидата в приватні детективи знову пропонувалося закріпити вимогу щодо проходження відповідного навчання, що, на нашу думку, є необхідною умовою для набуття статусу приватного детектива. Аналіз положень Законопроєкту від 8 лютого 2019 р. № 10024 [8] свідчить про те, що серед основних вимог до кандидата у приватні детективи зазначено такі: громадянство, вік (21 рік), володіння державною мовою, наявність вищої освіти або стажу роботи в оперативних підрозділах чи органах досудового розслідування не менше трьох років, проходження відповідного навчання задля здійснення приватної детективної (розшукової) діяльності та отримання у встановленому законом порядку свідоцтва про право на зайняття приватною детективною (розшуковою) діяльністю.

Чергові спроби врегулювати сферу приватної детективної діяльності в Україні віддзеркалюють ще два законопроєкти, опубліковані нещодавно на сайті Верховної Ради України. Якщо проєкт «Про приватну детективну (розшукову) діяльність» від 2 вересня 2019 р. № 1228 [9] € «реінновацією» проаналізованих Законопроєктів та нічого принципово нового не містить до вимог, які висуваються до претендентів на зайняття приватною детективною діяльністю, то розділ VII Законопроєкту «Про детективні послуги» від 20 вересня
2019 р. № 1228-1 [10], яким пропонується перелік кваліфікаційних вимог до приватних детективів, потребує детального аналізу, оскільки від якості зазначених норм буде залежати функціонування зазначеного виду недержавної правоохоронної діяльності в Україні. Почнемо аналіз зі ст. 41 Законопроєкту, якою пропонується встановити вимоги до приватного детектива-кандидата, i цей перелік суттєво розширено порівняно 3 попередніми пропозиціями законотворця. Важливо, що кваліфікаційні вимоги до кандидатів у приватні детективи передбачають наявність освіти, відсутність судимості, компетентність фахового змісту, проте однозначно погодитися не можна 3 низкою запропонованих новел.

1) Пункт 5 ст. 41 Законопроєкту передбачає, що особа може звернутися за ліцензією, якщо проти неї не ведеться ніякого судового розгляду щодо умисного злочину або навмисного фінансового злочину. Запропонована норма заборони доступу до професії детектива суперечить ст. 62 Конституції України.

$\begin{array}{llll}\text { 2) Пункт } 8 & \text { ч. } 1 & \text { ст. } 41\end{array}$ Законопроєкту дозволяє звертатися за ліцензією приватного детектива, якщо особа володіє позитивним висновком керівника районного, міського органу Національної поліції за місцем державної реєстрації особи або за місцем іiі постійного проживання у термін не менше 5 років, складеного на основі відомостей, які на актуальний час має у своєму розпорядженні орган Національної поліції або в разі громадянства іншої країни орган відповідного рівня й компетенції держави, компетентний щодо іiі місця проживання. Отже, виходячи 3 тексту запропонованої норми, розуміємо, що висновок (фактично характеристикарекомендація) щодо кандидата у приватні детективи формується керівником органу Національної поліції, проте зауваження викликає некоректне формулювання «на основі відомостей на актуальний час». 
3) $\mathrm{He}$ можна погодитися 3 формулюванням п. 9 аналізованої статті, в якій зазначено, що особа може звернутися за ліцензією, якщо володіє розумовою здатністю виконувати дії, спрямовані на виконання умов договорів про надання детективних послуг, зазначених у ст. 2 цього Закону, підтвердженою медичною довідкою. Оцінювання інтелектуальних можливостей кандидатів та їх придатність за станом здоров'я як вимога до кандидата у приватні детективи не викликає заперечень, оскільки $є$ поширеною практикою під час визначення кваліфікаційних професійних вимог, проте однозначно погодитись не можна 3 формулюванням «володіє розумовою здатністю», до того ж зовсім не зрозуміло, якою медичною довідкою кандидат повинен їх підтверджувати.

4) Нелогічним є п. 10 ч. 1 ст. 41 Законопроєкту, яким передбачається, що кандидат у приватні детективи повинен мати документи, що підтверджують освітню підготовку у сферах захисту персональних даних, захисту конфіденційної інформації та комерційної таємниці, захисту авторських прав, правового статусу приватного детектива, а також загальні принципи ведення господарської діяльності у сфері детективних послуг. В цьому аспекті аналізований Законопроєкт підтримати неможливо, оскільки він передбачає п'ять різноманітних видів навчання, підтверджених документами про освітню підготовку.

Отже, незважаючи на велику кількість законопроєктів, присвячених легалізації приватної детективної діяльності, спостерігається тенденція до фіксації вимог до претендентів на зайняття приватною детективною діяльністю. Водночас усі наведені пропозиції містять низку принципово різних підходів до встановлення вимог до спеціальності та освітньокваліфікаційного ступеня відповідних осіб. Слід відзначити, що нормативне визначення строку дії свідоцтва про проходження спеціальної підготовки кандидатом у детективи та терміну, що сплинув з моменту припинення служби в оперативних підрозділах чи органах досудового розслідування, взагалі залишилися поза увагою законодавця. У сукупності все зазначене зумовлює потребу виваженого підходу 3 боку законодавця до врегулювання правових засад набуття права на професійну приватну детективну (розшукову) діяльність в Україні.

\section{Література}

1. Юрко С. Недержавна охоронна і правоохоронна діяльність в Україні : дис. ... канд. юрид. наук : спец. 12.00.10. Одеса, 2017. 250 с.

2. Черков В. Приватна детективна діяльність в розвинутих країнах світу. Вісник Луганського державного університету внутрішніх справ імені Е. О. Дідоренка. 2010. Вип. 2. С. 248-259. URL: http://nbuv.gov.ua/UJRN/Vlduvs_2010_2_35.

3. Всеукраїнська асоціація приватних детективів. URL: https://aupd.com.ua/chlenstvo-vvachd.

4. Про приватну детективну діяльність : Проєкт Закону України від 7 квітня 2004 р. № 5380. URL: http://w1.c1.rada.gov.ua/pls/zweb2/webproc4_2?pf3516=5380\&skl=5.

5. Про приватну детективну (розшукову) діяльність : Проєкт Закону України від

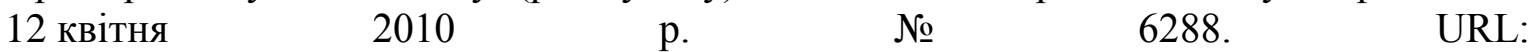
http://search.ligazakon.ua/1_doc2.nsf/link1/JF4UO00A.html.

6. Про приватну детективну (розшукову) діяльність : Проєкт Закону України від 13 грудня $2012 \quad$ p. $2 N \quad 1093 . \quad$ URL: http://search.ligazakon.ua/__doc2.nsf/link1/JG0UD00A.html. 
7. Про приватну детективну (розшукову) діяльність : Проєкт Закону України від 28 грудня $2015 \quad$ p. $\quad$ № $3726 . \quad$ URL: http://w1.c1.rada.gov.ua/pls/zweb2/webproc4_1?pf3511=57580.

8. Про приватну детективну (розшукову) діяльність : Проєкт Закону України від $\begin{array}{llllll}2 \text { вересня } & 2019 & \text { p. } & \text { № } & 1228 . & \text { URL: }\end{array}$ http://search.ligazakon.ua/1_doc2.nsf/link1/JI00316A.html.

9. Про приватну детективну (розшукову) діяльність : Проєкт Закону України від $\begin{array}{llllll}8 \text { лютого } & 2019 & \text { p. } & N & 1024 . & \text { URL: }\end{array}$ http://w1.c1.rada.gov.ua/pls/zweb2/webproc4_1?pf3511=65453.

10. Про детективні послуги : Проєкт Закону України від 20 вересня 2019 р. № 1228-1. URL: http://search.ligazakon.ua/l_doc2.nsf/link1/JI00521A.html.

\section{References}

1. Yurko, S. (2017), "Non-government security and law enforcement activity in Ukraine", Thesis abstract for Cand. Sc. (Jurisprudence), 12.00.10, Odesa, Ukraine.

2. Cherkov, V. (2010), "Private detective activity in developed countries of the world", Visnyk Luhanskoho derzhavnoho universytetu vnutrishnikh sprav imeni E. O. Didorenka, Iss. 2. pp. 248-259, available at: http://nbuv.gov.ua/UJRN/Vlduvs_2010_2_35.

3. "All-Ukrainian Association of Private Detectives", available at: https://aupd.com.ua/chlenstvo-v-vachd.

4. "On Private Detective Activity" : Draft Law of Ukraine dated 07.04.2004 No. 5380, available at: http://w1.c1.rada.gov.ua/pls/zweb2/webproc4_2?pf3516=5380\&skl=5.

5. "On Private Detective (Search) Activity" : Draft Law of Ukraine dated 12.04.2010 No. 6288, available at: http://search.ligazakon.ua/1_doc2.nsf/link1/JF4UO00A.html.

6. "On Private Detective (Search) Activity" : Draft Law of Ukraine dated 13.12.2012 No. 1093, available at: http://search.ligazakon.ua/1_doc2.nsf/link1/JG0UD00A.html.

7. "On Private Detective (Search) Activity" : Draft Law of Ukraine dated 28.12.2015 No. 3726, available at: http://w1.c1.rada.gov.ua/pls/zweb2/webproc4_1?pf3511=57580.

8. "On Private Detective (Search) Activity" : Draft Law of Ukraine dated 02.09.2019 No. 1228, available at: http://search.ligazakon.ua/1_doc2.nsf/link1/JI00316A.html.

9. “On Private Detective (Search) Activity” : Draft Law of Ukraine dated 08.02.2019 p. No. 1024, available at: http://w1.c1.rada.gov.ua/pls/zweb2/webproc4_1?pf3511=65453.

10. "On Detective Services" : Draft Law of Ukraine dated 20.09.2019 No. 1228-1, available at: http://search.ligazakon.ua/l_doc2.nsf/link1/JI00521A.html. 


\section{РОЗДІЛ V. КРИМІНАЛЬНИЙ ПРОЦЕС ТА КРИМІНАЛІСТИКА; ОПЕРАТИВНО-РОЗШУКОВА ДІЯЛЬНІСТЬ}

УДК 343.1:343.162:35.075.6

DOI https://doi.org/10.26661/2616-9444-2019-2-08

\section{Щодо тривалості повноважень слідчого судді в кримінальному провадженні}

\section{Войтович С. М.}

Запорізький національний університет, вул. Жуковського, 66, м. Запоріжжся, Украӥна e.m.voytovich@gmail.com

\section{Ключові слова:}

кримінальний прочес, судовий контроль, оскарження дій, бездіяльності, оскарження рімень, реформування, інститут кримінального переслідування, судова система.

Надійшло до редколегії: 09.09.2019

Прийнято до друку: 17.10.2019
У статті розглянуто особливості законодавчого врегулювання інституту судового контрою в кримінальному процесі України. Зокрема, надано визначення судового контрою як самостійного інституту процесуального закону з урахуванням як останніх змін процесуального законодавства, так і змін, які почнуть діяти в законодавстві 31 січня 2020 року щодо досудового розслідування кримінальних проступків. Зазначено недосконалість певних термінів процесуального закону, які, окрім іншого, впливають на зміст інституту судового контролю. Так, піддано критиці положення процесуального закону, які регулюють стадію закінчення досудового розслідування, що впливає на межі повноважень слідчого судді. Визначено критерії початку та закінчення строку повноважень слідчого судді стосовно конкретного кримінального правопорушення (конкретного кримінального провадження), а саме початок строку визначений виникненням права на звернення до слідчого судді, а закінчення - втратою такого права одночасно 3 моментом закінчення стадії досудового розслідування. Запропоновано вважати моментом втрати права на звернення до слідчого судді саме момент завершення досудового розслідування, який визначається рішенням слідчого та прокурора, про яке повідомляються учасники провадження та яке передує відкриттю матеріалів такого провадження. Звернено увагу на недоліки законодавчого врегулювання щодо невизначеності обсягу повноважень посадових осіб сторони обвинувачення в разі повернення обвинувального акту прокурору як такого, що не відповідає вимогам процесуального закону. Запропоновано рекомендації змін чинного процесуального закону, спрямовані на усунення зазначених недоліків. 


\section{Concerning the duration of the powers of the investigating judge in criminal proceedings}

\section{Voitovich E. M.}

Zaporizhzhia National University, str. Zhukovskoho, 66, Zaporizhzhia, Ukraine

e.m.voytovich@gmail.com

Key words:

criminal proceedings, judicial review, appeal against actions, inaction, appeal against decisions, reform, institute of criminal inaction, appeal against decisions, reform, institute of criminal prosecution, judicial system.
The article deals with the peculiarities of legislative regulation In particular, the definition of judicial review as an independent institution is given and the definition of judicial control as an independent institute of procedural law, taking into account both recent changes in procedural law, taking into account both recent changes in procedural legislation, the law, as well as changes in law taking into account changes that will come into force in the law from January 1, 2020 on pre-trial investigation of criminal offenses on pre-trial investigation of criminal offenses. The status of the investigating judge of the court of first instance, the appellate court and the High Anticorruption Court is pointed out. The imperfection of certain terms of the procedural law, which, among other things, affect the content of the terms of the procedural law, which, among other things, affect the content of the institution of judicial review. It is suggested to consider the moment of beginning institute of judicial control powers of the investigating judge has expired 24 hours from the date of receipt by the investigator or the prosecutor of information about the criminal offense. Or the prosecutor of the information about the committed criminal offense is suggested to consider the moment of beginning institute of judicial control powers of the investigating judge has expired 24 hours from the date of receipt by the investigator or the prosecutor of information about the criminal offense. Or the prosecutor of the information about the committed criminal offense. Investigation stage proposed to consider the moment of loss of the right to appeal to the investigating judge at the moment of the loss of the right to appeal to the investigating judge at the very moment of completion, pretrial investigation, determined by the decision of the investigator and prosecutor, who are informed about the proceedings, the participants will continue at the same time, the stage of pre-trial investigation is not completed, since the indictment or the relevant procedural request has not yet been sent to the court. Investigation stage is proposed to consider the moment of loss of the right to appeal to the investigating judge at the moment of the loss of the right to appeal to the investigating judge at the very moment of completion, pre-trial investigation, determined by the decision of the investigator and prosecutor, who are informed about the proceedings, the participants will continue at the same time, the stage of pre-trial investigation is not completed, since the indictment or the relevant procedural request has not yet been sent to the court. Investigation stage is proposed to consider the moment of loss of the right to appeal to the investigating judge at the moment of the loss of the right to appeal to the investigating judge at the very moment of completion, pre-trial investigation, determined by the decision of the investigator and prosecutor, who are informed about the proceedings, the participants will continue at the same time, the stage of pre-trial investigation is not completed, since the indictment or the relevant procedural request has not yet been sent to the court. Criticized by the duty of the 
investigating magistrate of the investigating given that the period of such familiarization is not included in the introduction, since the time of such a reading is not within the deadline. The principal possibility of additional investigation after the decision on its impossibility of additional investigation after the decision on its completion is emphasized. Proposed recommendations for changes in current procedural completion. Suggestions for changes are suggested the law seeks to remedy this shortcoming.

Кримінальний процесуальний закон загалом та інститут судового контролю в кримінальному процесуальному праві України зокрема зазнають змін. В чинному процесуальному законі контрольна функція суду прямо зазначена в нормативному документі, а не в доктрині права. Отже, полеміка, яка раніше точилася щодо наявності контрольних функцій суду на стадії досудового розслідування або їх відсутності, актуальна сьогодні лише щодо юридичної сутності цього інституту, його суб'єктів, меж, можливостей та механізмів. У статті пропонується висвітлити проблемні питання законодавчого врегулювання зазначеного інституту та визначити можливі напрями його подальшого розвитку щодо проблемних питань, які виникли під час застосування норм кримінального процесуального закону.

Питанням судового контрою та досліджень його певних елементів приділяли увагу вітчизняні та російські науковці, зокрема Н.М. Ахтирьска, В.М. Горшеньов, М.М. Куцин, В.А. Лазарєва, Л.М. Лобойко, В.Т. Маляренко, І.Л. Петрухін, А. Туманянц, Д.О. Філін, Н.М. Чепурнова, І.Б. Шахов, О.Г. Шило. Слід зазначити, що дослідженням певних елементів, які зараз утворюють інститут судового контролю, приділялась увага навіть правниками радянських часів, чому буде присвячена окрема робота.

Метою статті $є$ висвітлення недоліків законодавчого регулювання цього інституту, аналіз їх причин, пропозиція перспектив їх вирішення.
У попередніх роботах автором запропоновано таке визначення судового контролю в кримінальному процесі України: «судовий контроль в кримінальному судочинстві виражається в безпосередній перевірці законності та обгрунтованості рішень, дій та бездіяльності посадових осіб органів прокуратури, дізнання та досудового слідства на досудових стадіях кримінальної справи». Нині поняття «кримінальна справа» відсутня, існує лише кримінальне провадження, що більш точно відповідає сутності цього інституту 3 огляду на кількість стадій, їх детальну регламентацію та правила реєстрацій. Інститут дізнання скасований повністю, однак запропоновано запровадити кримінальні проступки та спрощений порядок їх досудового розслідування, що $\epsilon$ певним чином тотожним 3 інститутом дізнання. Таким чином, запропоновано визначити судовий контроль як безпосередню перевірку слідчим суддею законності та обгрунтованості рішень, дій або бездіяльності посадових осіб сторони обвинувачення на стадії досудового розслідування кримінального провадження.

Оскільки головним суб'єктом судового контролю $є$ саме слідчий суддя, окрім механізму обрання слідчого судді, який досліджено в попередніх роботах, пропонується дослідити межі повноважень слідчого судді в часі стосовно конкретного кримінального провадження (кримінального правопорушення).

Ha думку автора, межі повноважень слідчого судді мають бути визначені моментом виникнення права на 
звернення до нього у вигляді скарги чи клопотання та моментом закінчення такого права.

На перший погляд, початок повноважень слідчого судді стосовно конкретного кримінального правопорушення визначити нескладно, оскільки тлумачення терміна «слідчий суддя» закріплено у ст. 3 КПК України, а iз самої назви випливає можливість діяльності такого суб'єкта лише на стадії досудового розслідування. 3 тієї ж норми закону випливає, що стадія досудового розслідування починається 3 моменту внесення до Єдиного реєстру досудових розслідувань (далі - ЄРДР) відомостей про виявлене кримінальне правопорушення. Однак на вимогу приписів ст. 303 КПК України слідчий суддя уповноважений розглядати скарги на бездіяльність органу досудового розслідування, яка полягає у невнесенні до СРДР відомостей про кримінальне правопорушення, тобто до моменту початку стадії досудового розслідування. За таких обставин слід звернути увагу на вимоги ст. 214 КПК України, які зобов'язують слідчого, прокурора внести відомості про вчинене кримінальне правопорушення до СРДР невідкладно, але не пізніше 24 годин 3 моменту отримання відомостей про таке правопорушення незалежно від джерела їх походження. Отже, слід дійти висновку, що бездіяльність, яка підлягає оскарженню, починається саме зі спливем 24 годин 3 моменту отримання органом досудового розслідування, прокурором відомостей про вчинене кримінального правопорушення. На думку автора, саме сплив цього строку необхідно вважати початком повноважень слідчого судді щодо конкретного кримінального правопорушення.

Тривалість досудового розслідування залежить від багатьох чинників, однак строки досудового розслідування, які передбачені у ст. 219 КПК України, у будь-якому разі обмежують строк повноважень слідчого судді. Слід зауважити, що чинний процесуальний закон не встановлює жодних обмежень повноважень слідчого судді у випадках, коли досудове розслідування зупинене 3 тих чи інших причин, тобто обов'язки здійснювати судовий контроль не залежать від стану досудового розслідування.

Певна проблематика виявляється в разі визначення моменту закінчення повноважень слідчого судді.

Насамперед слід звернути увагу на непослідовність законодавців, яка проявляється у застосуванні тотожних за своїм семантичним навантаженням термінів, які регламентують стадію досудового розслідування. Йдеться про терміни «закінчення» та «завершення».

Термін «закінчення досудового розслідування» згадується у ст. 3 , гл. 24 КПК України, зі змісту яких випливає, що досудове розслідування $є$ закінченим в разі прийняття рішення про його закриття або направлення до суду певного процесуального документа, а саме обвинувального акту, або клопотання про звільнення обвинуваченої особи з підстав, передбачених кримінальним законом, або вжиття примусових заходів певного характеру. Між тим у ч. 1 ст. 290 КПК України йдеться саме про «завершення досудового розслідування», про яке слідчий або прокурор має повідомити підозрюваного, його захисника, законного представника та захисника особи, стосовно якої передбачається вжиття примусових заходів медичного чи виховного характеру. Після цього настає стадія відкриття матеріалів, строк тривалості якої не входить до строку досудового розслідування.

Цілком очевидним, насамперед, $\epsilon$ те, що терміни «завершення» та «закінчення» щодо семантичного наповнення та лінгвістики $є$ ідентичними, про що прямо зазначено: «завершення - те саме, що закінчення» [1, с. 934]. Проте щодо процесуального закону ці терміни мають різний зміст. 
3 огляду на приписи ч. 1 ст. 290 КПК України момент завершення досудового розслідування пов'язується 3 повідомленням учасників провадження про таке процесуальне рішення сторони обвинувачення. Уявляється правильним висновок про те, що 3 моменту такого повідомлення будь-кому 3 учасників припиняються можливості слідчого та прокурора проводити слідчі дії. Інший висновок суперечитиме самому змісту інституту відкриття матеріалів провадження іншій стороні, адже безпосередньо після такого повідомлення триватиме стадія відкриття матеріалів. Отже, матеріали, отримані після іiі здійснення, вже не $\epsilon$ не відкритими протилежній стороні, тому не можуть використовуватися судом. Слід також звернути увагу на те, що строк виконання процедури відкриття матеріалів іншій стороні не включається до строку досудового розслідування, що прямо передбачено ч. 3 ст. 219 КПК України. Однак після завершення процедури відкриття матеріалів сторона обвинувачення повинна виконати певні дії, а саме скласти обвинувальний акт та реєстр матеріалів досудового розслідування або клопотання про вжиття щодо особи примусових заходів, а прокурор повинен вручити примірники цих документів підозрюваному та його захиснику, що прямо передбачено ст. 293 КПК України. Ці дії вже включаються до строку досудового розслідування, a їх тривалість потенційно не є обмеженою 3 огляду на різні чинники, які виникають в ході розслідування. Отже, існує проміжок часу, коли досудове розслідування $\epsilon$ завершеним, але не є закінченим.

В такій ситуації постає запитання про те, чи повноважний слідчий суддя здійснювати судовий контроль у період, коли досудове розслідування $\epsilon$ завершеним, але не $\epsilon$ закінченим.

Процесуальний закон надає відповідь на це запитання шляхом покладення на слідчого суддю обов'язку за клопотанням сторони провадження встановити протилежній стороні строк для ознайомлення 3 матеріалами в разі зволікання під час ознайомлення 3 матеріалами провадження, після спливу якого сторона кримінального провадження або потерпілий, представник юридичної особи, щодо якої здійснюється провадження, вважаються такими, що реалізували своє право на доступ до матеріалів. Це прямо закріплено в ч. 10 ст. 290 КПК України.

На думку автора, цю позицію законодавців слід піддати критиці з таких міркувань.

Насамперед, санкція ч. 10 ст. 290

КПК України зводить нанівець дискреційні повноваження слідчого судді як суб'єкта носія саме судової влади, оскільки не залишає можливості відмови щодо задоволення клопотання сторони провадження в разі його необгрунтованості, адже встановлює саме безальтернативний обов'язок встановлення певного строку в разі заявлення такого клопотання. Отже, незалежно від мотивації заявника клопотання та його підтвердження фактичними обставинами слідчий суддя вже зобов'язаний; така правова конструкція створює передумови для зловживань 3 боку будь-якої сторони провадження; закладено також підстави для корупційних зловживань, оскільки будь-які законодавчі підгрунтя для вирішення такого клопотання не визначені (ні строки подання, ні його суб'єкти, ні строки та порядок розгляду клопотання, ні коло суб'єктів, які мають право на участь у такому розгляді, ні обставини, які повинні братися до уваги під час його розгляду). До того ж слід зазначити, що конструкція «зволікання під час ознайомлення» наповнена певним змістом лише в розумінні особи, яка нею користується, тобто є суто суб'єктивною й такою, яка позбавлена формальної визначеності, що притаманне саме правовій нормі.

Слід взяти до уваги також те, що строк, протягом якого триває відкриття 
матеріалів сторонами, не входить до строку досудового розслідування, але входить до строку дії запобіжних заходів у вигляді домашнього арешту або тримання під вартою, які вибрані щодо підозрюваного. За таких обставин досліджуване повноваження слідчого судді неповністю відповідає завданням судового контролю, адже можливості сторони обвинувачення на збирання доказів вичерпані фактом завершення досудового розслідування. Жодної заборони на ознайомлення 3 матеріалами досудового розслідування для підозрюваної або обвинуваченої особи не існує на жодній стадії. $€$ певні недоліки законодавчого врегулювання доступу до матеріалів досудового розслідування для захисника, який прийняв доручення на захист після виконання сторонами вимог ст. 290 КПК України, однак цим питанням буде надано увагу в окремому дослідженні найближчим часом.

Викладене дає підстави для висновку. На думку автора, повноваження слідчого судді будь-якого рівня (перша або друга інстанції, Вищий антикорупційний суд) мають закінчуватися саме в момент завершення, а не закінчення досудового розслідування, окрім випадків, про що буде зазначено нижче.

Можуть виникнути аргументи на противагу щодо можливої необхідності заходів забезпечення у вигляді арештів майна, дії запобіжних заходів щодо підозрюваного, покладання на нього обов'язків тощо саме в період між завершенням та закінченням досудового розслідування. Спростування цих аргументів не може складати труднощів, адже вирішення питання щодо накладення арешту на майно підозрюваного, або на тимчасово вилучене майно не $\epsilon$ проблемою протягом двох місяців, які становлять строк звичайного досудового розслідування. Певні технічні складнощі можуть становити питання продовження дії запобіжних заходів та тривання обов'язків підозрюваного, які передбачені ст. 194 КПК України. Однак ці труднощі не $\epsilon$ неподоланними, питання обгрунтовано лише організацією роботи відповідного слідчого підрозділу. Щодо балансу інтересів суспільства та особи перевага повинна бути надана саме інтересам особи щодо здійснення повноважень сторони обвинувачення.

Залишається відкритим питання можливості здійснення контрольних функцій слідчими суддями в момент, коли досудове розслідування завершено, однак перед слідчим суддею поставлене питання, що входить до його компетенції, до такого завершення. Йдеться про право заявити скаргу або клопотання перед використанням стороною обвинувачення права повідомити учасників провадження про завершення досудового розслідування, однак за умови того, що 3 тих чи інших підстав слідчий суддя не розглянув питання, які перед ним поставлені.

Під час вирішення цього питання слід виходити із загальних принципів кримінального процесуального закону та приписів Конституції України. Зокрема, з права оскаржувати дії та рішення, яке передбачено ст. 24 КПК України, та права доступу до правосуддя, яке закріплено у ст. 55 Конституції України. Будь-яке право має кореспондуватися з обов'язком таке право реалізувати, адже інакше таке право перетворюється на пусту декларацію. Отже, наявне право звернутися до слідчого судді породжує обов'язок слідчого судді таке звернення розглянути незалежно від того, чи $\epsilon$ досудове розслідування завершеним або навіть закінченим.

Певні неузгодженості породжує ст. 314 КПК України. Однією із засад прийняття Кримінального процесуального кодексу України у 2012 році була необхідність усунення інституту додаткового розслідування, який, безумовно, був важливим чинником, що впливав на дотримання прав людини 3 огляду на кримінальне переслідування. Однак ст. 314 КПК України дає суду 
право повернути прокурору обвинувальний акт як такий, що не відповідає вимогам процесуального закону. Проводити аналогії цього процесуального рішення 3 інститутом додаткового рішення не $є$ коректним, ця тема потребує окремого дослідження, проте слід констатувати, що наявна теоретична й практична проблема.

Так, 3 огляду на прямі приписи ст. 3 КПК України стадія досудового розслідування закінчилася в момент направлення до суду обвинувального акту або іншого процесуального клопотання. Інститут поновлення досудового розслідування пов'язаний лише 3 випадками його зупинення, що однозначно врегульовано приписами гл. 23 КПК України. У жодних інших випадках досудове розслідування не поновлюється. Слід визнати, що будь-які повноваження слідчого закінчилися в цей момент. Залишається відкритим питання щодо повноважень процесуального керівника, адже ч. 11 ст. 290 КПК України побічно припускає можливість отримання доказів прокурором і після направлення обвинувального акта до суду. Однак залишається відкритим питання щодо процесуальних механізмів такого отримання, гарантій дотримання конституційних прав учасників провадження під час отримання доказів поза строками розслідування, фіксації результатів таких невизначених дій. Не $\epsilon$ однозначно вирішеним питання щодо права прокурора прийняти процесуальне рішення про закриття кримінального провадження після повернення обвинувального акта, змінити кваліфікацію дій винної особи, формулювання обвинувачення тощо.

Проте слід визнати той факт, що iснує певний проміжок часу між поверненням обвинувального акта прокурору та повторним направленням обвинувального акта до суду. Процесуальний закон не надає відповіді на питання щодо обсягу повноважень посадових осіб сторони обвинувачення в цей час. Однак 3 огляду на приписи ст. 3 КПК України цей час не можна вважати таким, що входить у стадію досудового розслідування, отже, можливості звернення до слідчого судді в цей час не iснує.

Підсумовуючи

наведене, констатуємо значні прогалини в законодавстві у сфері правового регулювання контрольної діяльності суду, отже, в цій сфері потрібні подальші теоретичні розробки та практичні зміни. Безумовно, прийняття Кримінального процесуального кодексу України вирішило певні проблеми в цій сфері, які існували до 19 листопада 2012 року, однак лише правозастосовна практика та теоретичні розробки сприятимуть утвердженню законності, оскільки проблеми, які існували до цієї дати, однозначно не вирішені. Подолати цю ситуацію можна шляхом усунення суперечностей $\quad$ у термінології процесуального закону, визначення повноважень посадових осіб сторони обвинувачення на стадії повернення обвинувального акта прокурору тощо.

\section{Література}

1. Словник української

мови.

URL: https://services.ulif.org.ua/expl/Entry/index?wordid=27943\&page=933 (дата звернення: 09.05.2019).

\section{References}

1. Slovnyk ukrainskoi movy [Dictionary of Ukrainian], available at : https://services.ulif.org.ua/expl/Entry/index?wordid=27943\&page=933 (access 09.05.2019). 


\section{Проблемні питання проведення слідчих (розшукових) дій, які супроводжуються вилученням електронних носіїв інформації}

Сна I. B.

Запорізький наџіональний університет, вул. Жуковського, 66, м. Запоріжжся, Україна ena-irina@ukr.net

\section{Ключові слова:}

електронні носії інформації, інформачійне суспільство, інформатизачія, експертна діяльність.

Надійшло до редколегї: 09.09.2019

Прийнято до друку: 17.10.2019
У статті досліджено складнощі, які виникають у практичній діяльності правоохоронних органів під час розслідування комп'ютерних злочинів, зокрема проблеми, які виникають під час проведення слідчих (розшукових) дій, які спрямовані на отримання доказово значущої інформації у провадженні та супроводжуються вилученням електронних носіїв інформації. Запропоновано правила їх ефективного вилучення.

\section{Problems of issues of the investigative (definitive) actions the extraction of electronic media} Yena I. V.

Zaporozhye National University, str. Zhukovski, 66, Zaporizhzhya, Ukraine ena-irina@ukr.net

Key words:

electronic media, evidence, sources of evidence information society, informatization, expert activity.
The article explores the difficulties that law enforcement agencies have in the investigation of computer crimes. Including problems that arise when conducting investigative (investigative) actions that are aimed at obtaining provably meaningful information and are accompanied by the seizure of such a specific source of evidence as electronic media. In addition, rules are proposed that comply with which can ensure the effectiveness of the removal of electronic storage media and the possibility of further use of the data obtained in the process of proof.

Sufficient conditions for further development of the information society have been created in Ukraine. However, there are a number of problems that affect this process, which can be attributed to: unjustifiably low availability of modern computer hardware not only for individual sectors of the economy, but also for entire regions, different sections of the population; poor computer literacy (especially for people over fifty); lagging behind the introduction of e-business technologies, etc.

In addition, there are factors that complicate the investigation of this category of unlawful acts: 1) insufficient logistical support for law enforcement units investigating computer crimes; 2) lack of proper level of cooperation and mutual information with law enforcement agencies of other countries, and this cooperation should be established, as cybercrime is transnational; 3 ) the basis of the national cybersecurity system is a fairly wide range of ministries and agencies and this leads to a lack of coordination of their actions; 4) the complexity of the construction of legal norms, which affects the correct qualification of this type of crime; 5) timeliness of investigative (investigative) actions also poses a 
certain problem, etc.

In this way, we can formulate general rules that can be used to ensure that electronic data retrieval is effective and that the data obtained can be further used in the proofing process. First, the person who removes the electronic storage media must have special knowledge, training and skills. Second, the general criminal procedural and expert provisions must be strictly observed. Third, the removal must be made in such a way that it does not alter, damage, or destroy the electronic medium and the information stored therein. Fourth, all actions that took place when detecting and removing electronic storage media should be fully documented in the procedural documents.

Інформаційна сфера суспільства сьогодні є галуззю людської діяльності, яка найбільш динамічно розвивається. Суспільство стає більш інформаційно насиченим. Ми можемо констатувати формування інформаційного суспільства, якому притаманні такі ознаки, як наявність відкритих можливостей для будь-якої фізичної особи отримувати будь-яку інформацію для вирішення питань особистого чи суспільного характеру; наявність та доступність сучасної інформаційної технології будьякій фізичній чи юридичній особі; розвиненість інформаційної інфраструктури; створення національних інформаційних ресурсів; прискорена автоматизація та роботизація всіх сфер i галузей національного господарства; розширення сфери інформаційної діяльності; зростання кількості зайнятих в інформаційній сфері національного господарства [1, с. 78]. Основною

характеристикою інформаційного суспільства $\epsilon$ його глобальна інформатизація. Інформатизація - це сукупність взаємопов'язаних організаційних, правових, політичних, соціальноекономічних, науково-технічних, виробничих процесів, що спрямовані на створення умов для задоволення інформаційних потреб, реалізацію прав громадян i суспільства на основі формування, розвитку, використання інформаційних систем, мереж, ресурсів та інформаційних технологій, створених на основі застосування сучасної обчислювальної та комунікаційної техніки [2]. Інформатизація $є$ важливою властивістю суспільства та впливає на всі сфери людського життя, оскільки забезпечує підвищення рівня організації праці, освіти, швидкості виконання послуг, поширення інформації серед населення, у виробництво запроваджуються високі технології, 3'являються нові галузі виробництва, полегшується та пришвидшується процес здійснення фінансових операцій тощо.

$$
\text { Про активізацію процесу }
$$

інформатизації в Україні на державному рівні свідчать розроблення та введення в дію Законів України «Про електронні документи та електронний документообіг», «Про електронний цифровий підпис», Концепції Національної програми інформатизації, схваленої Законом України «Про Концепцію Національної програми інформатизації», Закону України «Про Національну програму інформатизації». Задля повноцінного переведення роботи органів виконавчої влади в електронну форму у 2018 році прийнято Постанову КМУ «Деякі питання документування управлінської діяльності», яка визначає електронну форму діловодства як основну для установ i підприємств державного сектору. Відповідно до Закону України «Про місцеве самоврядування в Україні» здійснюється запровадження технологій електронного урядування в місцевих органах виконавчої влади та органах місцевого самоврядування.

Місцева влада також не стоїть осторонь процесу інформатизації, про що свідчить розроблення Програм інформатизації в таких областях України, як Львівська, Вінницька, Одеська, 
Рівненська,

Харківська, Дніпропетровська, тощо, запровадження яких дасть змогу інтегрувати області до загальнодержавного та світового інформаційного простору. Отже, ми можемо стверджувати, що в Україні створені достатні умови для подальшого розвитку інформаційного суспільства, проте існує низка проблем, які впливають на цей процес, до яких можна віднести невиправдано низький рівень забезпеченості сучасною комп'ютерною технікою не тільки окремих галузей економіки, але й цілих регіонів, різних верств населення; низький рівень комп'ютерної грамотності населення (особливо це стосується людей віком старше п'ятдесяти років); відставання запровадження технологій електронного бізнесу.

Сподіваємось на те, що такі перепони будуть усунуті найближчим часом, оскільки у 2017 році за Розпорядженням Кабінету Міністрів України було розроблено Концепцію розвитку електронного урядування, відповідно до якої передбачається до 2020 року вжити заходів за такими трьома ключовими напрямами:

- модернізація публічних послуг (100 найбільш важливих онлайн-послуг для громадян та бізнесу);

- модернізація публічного управління (електронна взаємодія реєстрів);

- управління розвитком еурядування (впровадження міжнародного досвіду роботи з державними актами за принципом "digital by default").

Масштабне формування інформаційного суспільства не тільки має позитивні аспекти, але й виводить на передній план проблему забезпечення безпеки інформації, як наслідок, охорони державних, суспільних, приватних інтересів. Так, Законом України «Про основи національної безпеки України» визначено, що на сучасному етапі основними реальними та потенційними загрозами національній безпеці України, стабільності в суспільстві та інформаційній сфері $є$ прояви обмеження свободи слова та доступу до публічної інформації; поширення засобами масової інформації культу насильства, жорстокості, порнографії; комп'ютерна злочинність та комп'ютерний тероризм; розголошення інформації, яка становить державну таємницю, або іншої інформації 3 обмеженим доступом, спрямованої на задоволення потреб i забезпечення захисту національних інтересів суспільства й держави; намагання маніпулювати суспільною свідомістю, зокрема, шляхом поширення недостовірної, неповної або упередженої інформації (ст. 7) [3].

Як бачимо, нові технології породжують нові глобальні проблеми, однією 3 яких $\epsilon$ поява комп'ютерної злочинності, яка є в переліку, наведеному вище. Саме цей вид злочинної діяльності в сучасних умовах розвитку української державності отримав особливого значення, оскільки Україна живе в той час, коли всі громадяни держави, підприємства, установи, організації $€$ незахищеними перед атаками кіберзлочинців. Ускладняється ситуація також тим, що комп'ютерна злочинність $€$ специфічним різновидом злочинності, якому притаманний високий півень латентності; недостатня увага приділяється дослідженню кримінологічних, криміналістичних, кримінальних процесуальних проблем, пов'язаних 3 визначенням напряму розслідування, висуненням та відпрацюванням версій, особливостям провадження слідчих (розшукових) дій, дослідженням проблемних питань пошуку та закріпленням доказової інформації. Проте дослідження в цьому напрямі здійснюються. Вказана проблематика була в колі наукових досліджень таких учених, як Д.С. Азаров, М.В. Карчевський, Н.А. Розенфельд, П.Д. Біленчук, Н.І. Клименко, А.В. Іщенко, М.С. Вертузаєв, Т.В. Варфоломеєва. Однак досі залишається багато проблем, які впливають на ефективність розслідування цього виду злочинних дій, повноту, всебічність та об'єктивність дослідження обставин справи.

Одним $з$ таких проблемних питань $\epsilon$ питання правильного вилучення електронних носіїв інформації, які були виявлені в рамках розслідування під час проведення слідчих (розшукових) дій. Перш ніж розглядати питання ефективності вилучення електронних 
носіїв інформації, слід приділити увагу з'ясуванню сутності поняття «електронний носій».

Електронний носій - це матеріальний носій, який використовують для записування, зберігання та відтворення інформації, обробленої засобами комп'ютерної техніки. До електронних носіїв належать жорсткі диски, флеш-пам'ять, CD-, DVD-, Blueray-диски, дискети, касети на магнітній стрічці тощо [4, с. 25].

Наведений перелік ми вважаємо неповним, оскільки технічний прогрес не стоїть на місці, запроваджуються нові технології, виготовляються сучасні технічні пристрої, тому ми пропонуємо розширити список, включивши до нього пластикові карти, електронні записники, відеорегістратори, мобільні телефони, планшети. Таке доповнення ми мотивуємо тим, що вказані технічні пристрої виконують специфічні функції завдяки вмонтованим відеокамерам, фотокамерам, можливостям звукозапису, розширенню можливостей користування мережею Інтернет тощо.

Зазначені носії інформації мають суттєве значення для розслідування й розкриття кримінальних правопорушень, будучи таким джерелом доказів, як документи. Відповідно до ст. 99 КПК України матеріали фотозйомки, звукозапису, відеозапису та інші носії інформації (зокрема, електронні) можуть належати до документів, якщо вони спеціально створені задля збереження інформації, містять зафіксовані за допомогою письмових знаків, звуку, зображення відомості, які можуть бути використані як доказ факту чи обставин, що встановлюються під час кримінального провадження [5].

Однак за інших обставин такий носій інформації може виступати в ролі іншого джерела, а саме як речовий доказ. Такий висновок грунтується на тому, що перераховані вище різновиди електронних носіїв загалом $\epsilon$ предметами матеріального світу, тобто речами, які виготовлені для зберігання інформації, іiі використання, трансформації тощо. В цьому разі критерієм, за яким можна відмежувати речові докази від суміжних джерел, є властивості носія інформації. Якщо електронний носій був використаний як знаряддя злочину (наприклад, на флешці зберігалась вірусна програма, за допомогою якої здійснювалася крадіжка інформації, грошових коштів); якщо він зберіг на собі сліди злочину або інші відомості, які мають доказове значення (наприклад, на $\mathrm{CD}$, який має глянцеву поверхню, можуть бути збережені чіткі відбитки пальців); якщо носій був об'єктом злочинного посягання (наприклад, крадіжка мобільного телефону), електронний носій інформації $є$ речовим доказом. Це питання сьогодні є дискусійним, тому докладніше буде розглядатися в рамках іншого дослідження. Проте до якого б із джерел доказів не належали електронні носії інформації, вони повинні бути виявлені й належним чином зафіксовані.

Найбільш результативними в аспекті виявлення доказової інформації, яка міститься саме на електронних носіях, ми вважаємо такі слідчі (розшукові) дії, як обшук та огляд, під час проведення яких слідчий повинен добре розбиратися в особливостях специфічного кіберпростору, володіти спеціальною термінологією тощо. На жаль, ми можемо констатувати, що сьогодні правоохоронні органи мають дефіцит слідчих, співробітників оперативних підрозділів, які $\epsilon$ фахівцями в галузі інформаційнокомунікаційних технологій, а кіберзлочинці, як правило, $\epsilon$ висококваліфікованими програмістами.

Крім того, є такі фактори, які ускладнюють розслідування цієї категорії протиправних діянь:

1) недостатнє матеріальнотехнічне забезпечення підрозділів правоохоронних органів, які розслідують комп'ютерні злочини;

2) відсутність належного рівня співпраці та взаємної поінформованості 3 правоохоронними органами інших держав, а ця співпраця повинна бути налагоджена, оскільки кіберзлочини мають транснаціональний характер;

3) досить широке коло міністерств та відомств, що становить основу національної системи 
кібербезпеки, тому це приводить до не координованості їх дій;

4) складність конструкції правових норм, що впливає на правильну кваліфікацію цього виду злочинів;

5) своєчасність виконання слідчих (розшукових) дій.

Своєчасність виконання слідчих (розшукових) дій також $\epsilon$ певною проблемою, оскільки, 3 одного боку, специфіка цього виду злочинів вказує на те, що будь-яке зволікання $\epsilon$ неприпустимим, а 3 іншого боку, необгрунтований поспіх також може спричинити шкоду, виправити яку може бути складно, а іноді навіть неможливо. Саме тому ми вважаємо, що 3 моменту отримання оперативної інформації про вчинений злочин і впродовж виконання слідчих (розшукових) дій, в результаті проведення яких може бути отримана доказово значуща інформація, має пройти якомога менше часу, що мінімізує спроби зацікавлених осіб вчинити дії, спрямовані на приховування або знищення важливої для слідства інформації та допоможе слідчому сформувати інформаційну базу, яка створить якісну систему доказів.

Однак реалізацію цього положення ускладнює те, що, як правило, на момент прийняття рішення про початок кримінального провадження слідчий ще не має достатнього обсягу інформації, яка допоможе визначити напрям розслідування, тому слідчому необхідно мати певний час на те, щоб отримати та опрацювати певний обсяг інформації.

Найбільш ефективною в цьому разі $\epsilon$ предметна форма фіксації отриманих результатів, яка є вилученням об'єкта в натурі та його консервацією, виготовленням матеріальних моделей (реконструкцією), зокрема макетування, копіювання, одержання відбитків, виготовлення зліпків [6, с. 19]. Отже, ми можемо сформулювати загальні правила, дотримання яких дасть змогу забезпечити ефективність вилучення електронних носіїв інформації та можливість подальшого використання отриманих даних в процесі доказування.

По-перше, особа, яка вилучає електронні носії інформації, повинна мати спеціальні знання, підготовку та навички. По-друге, повинні бути суворо дотримані загальні кримінальні процесуальні та експертні положення. По-третє, вилучення має бути здійснено таким чином, щоб не змінити, не пошкодити або не знищити електронний носій та інформацію, яка на ньому зберігається. По-четверте, всі дії, які мали місце під час виявлення та вилучення електронних носіїв інформації, повинні бути максимально повно задокументовані в процесуальних документах. По-п'яте, експерт, який буде в подальшому проводити дослідження носія інформації, повинен ретельно та акуратно проводити всі необхідні маніпуляції з об'єктом, не допускаючи його змін та несучи за нього відповідальність.

\section{Література}

1. Кахович О. О. Розвиток інформаційного суспільства : загрози для людини і держави. Економічна та інформаційна безпека: проблеми та перспективи: матеріали Всеукраїнської науково-практичної конференції (14 квітня 2017 року, м. Дніпро). Дніпро : Дніпропетровський державний університет внутрішніх справ, 2017. С. 77-79.

2. Про Концепцію Національної програми інформатизації : Закон України від 4 лютого 1998 року. URL : https ://zakon.rada.gov.ua/laws/show/75/98-\%D0\%B2\%D1\%80/print.

3. Про основи національної безпеки України : Закон України від 19 червня 1993 року № 964-I. URL : http ://zakon2.rada.gov.ua/laws/show/964-15.

4. ДСТУ 7448 :2013. Інформація та документація. Бібліотечно-інформаційна діяльність. Терміни та визначення понять [Чинний від 2014]. Київ : Мінекономрозвитку України, 2014. 41 с.

5. Кримінальний процесуальний кодекс України від 13 квітня 2012 року. URL : https ://zakon.rada.gov.ua/laws/main/4651-17. 
6. Лысов Н.Н. Криминалистическое учение о фиксации доказательственной информации в деятельности по выявлению и раскрытию преступлений : автореф. дисс. ... докт. юрид. наук : спец. 12.00.09. Москва, 1995. 31 с.

\section{References}

1. Kahovich O. O. (2017), "Development of the information society: threats to the individual and the state", Ekonomizna ta informaziina bezpeka : problema ta perspektivi [Economic and Information Security: Challenges and Prospects]: materials of the All-Ukrainian Scientific and Practical Conference (April 14, 2017, Dnipro), Dnipro, pp. 77-79.

2. "On the Concept of the National Informatics Program": Law of Ukraine of February 4, 1998, available at: https ://zakon.rada.gov.ua/laws/show/75/98-\%D0\%B2\%D1\%80/print (access November 20, 2019).

3. "On the basics of Ukraine's national security" : Law of Ukraine of June 19, 1993 No. 964I, available at : http ://zakon2.rada.gov.ua/laws/show/964-15 (access November 18, 2019).

4. DSTU 7448 : 2013. Information and documentation. Library and information activities. Terms and definitions [Effective 2014]. Kyiv: Ministry of Economic Development of Ukraine, 2014. $41 \mathrm{p}$.

5. The Criminal Procedure Code of April 13, 2012, available at: https ://zakon.rada.gov.ua/laws/main/4651-17 (access November 20, 2019).

6. Lisov, N. N. (1995), "Forensic doctrine on the fixation of evidentiary information in the activity of detection and disclosure of crimes", Thesis abstract for Doct. Sc. (Jurisprudence), 12.00.09, Moscow, Russia.

УДК 343.132:343.144:329.78-058.53

DOI https://doi.org/10.26661/2616-9444-2019-2-10

\section{Особливості допиту підозрюваного - члена молодіжної неформальної групи (об'сднання) під час досудового розслідування}

\section{Ларкін М. О.}

Запорізький національний університет, вул. Жуковського, 66, м. Запоріжжся, Украӥна malark777@ukr.net

\section{Ключові слова:}

допит, підозрюваний, молодь, неформальна

неформальне об 'єднання.

Надійшло до редколегії:

19.09.2019

Прийнято до друку: 27.10.2019
Стаття присвячена особливостям проведення допиту підозрюваного - члена молодіжної неформальної групи (об’єднання). Завдяки аналізу емпіричного матеріалу запропоновано рекомендації з проведення зазначеної слідчої (розшукової) дії. Наголошено на тому, що неодмінною умовою проведення допиту підозрюваного-неформала стає підготовка до нього, яка має бути вкрай ретельною. Розглянуто окремі тактичні прийоми, що можуть застосовуватися під час допиту зазначеної категорії осіб. Визначено тактичні ризики, з якими може стикнутися слідчий (прокурор). 


\title{
Features of the interrogation of the suspected member youth informal group (association) during the pre-trial investigation
}

\section{Larkin M. A.}

\author{
Zaporizhzhia National University, str. Zhukovskoho, 66, Zaporizhzhia, Ukraine \\ malark777@ukr.net
}

Key words:

interrogation, suspect, youth, informal group, informal association.

The article is devoted to the peculiarities of interrogation the suspected member of a youth informal group (association). Due to the analysis of empirical material, the recommendations for conducting the investigative (search) actions are offered.

An indispensable prerequisite for conducting a suspect-informal interrogation is preparation for him, which may take up to several days and must be extremely thorough. The investigator (prosecutor) should be fully acquainted with the biography of the suspect (including having a psychological portrait of the suspect), the specifics, structure of the youth informal group (association) to which he or she belongs, his place in it. It may be necessary to consult with a specialist who studies the activities of various youth informal entities. Thus, the questionnaire of the investigators showed that they never used the assistance of the said specialist during the preparation for the interrogation. The preparation itself was carried out only in $67 \%$ of cases.

Purposeful study of criminal proceedings materials is of great importance in preparing for the interrogation of a suspected member of a youth informal group (association).

The results of the investigation of investigators show that only $11 \%$ of the cases during the interrogation of the suspect - a member of the youth informal group (association) used the help of a specialist psychologist, which cannot but cause some concern.

If, during the interrogation, the suspect "closes in" and does not wish to answer the question of the investigator (prosecutor), then such tactical technique as "provocation of the suspect's views" may be used. The purpose of this tactical reception is to establish the presence of certain views, beliefs of the suspect. During the interrogation it is necessary to create a situation when a discussion arises and to "touch" the suspect (the investigator may express dissatisfaction with the state's policy; the cultural level of foreigners; disagree with any views of the victim; note that he adheres to the same religious beliefs or cares for the same club etc.). This can cause an emotional outburst on the suspect and cause him/her to express his/her point of view, which will allow the investigator to obtain the necessary information in the end, because, having become fascinated by the conversation, what really bothers $\mathrm{him} / \mathrm{her}$, the interrogator will cease to control himself and show the real motives of his/her behavior and actions.

During the interrogation of the suspect - a member of the youth informal group (association), and especially if he/she is conflicted, the investigator (prosecutor) should foresee tactical risks that may complicate or even negate all the work performed.

Слідчою (розшуковою) дією, проведення якої $є$ обов'язковим під час розслідування злочинів, що вчиняються членами молодіжних неформальних груп (об'єднань), є допит підозрюваного (підозрюваних). Результати його 
проведення без перебільшення мають визначальний характер для всього процесу розслідування.

Фактично допит загалом та підозрюваного зокрема - це «складний акт комунікативної взаємодії» [1, с. 63], який вимагає від слідчого (прокурора) ретельної підготовки, зосередженості, професійності та вміння прораховувати тактичні ризики. В.Л. Васильєв писав: «Слідчий - майстер, що за спрямованістю своєї діяльності схожий на досвідченого хірурга. Обом суспільство дало величезні права. Хірург своїм скальпелем вторгається у святая святих - живе тіло. Ніж хірурга висікає злоякісну пухлину на благо людині, для збереження здорових тканин, для порятунку іiі життя. <...> слідчий в ім'я інтересів суспільства та інтересів самої особистості має право вторгатися в інтимний, душевний світ людини і робить це відповідно до вимог закону. Допит - не менш складна процедура, ніж хірургічна операція. На допиті стикаються два різні світогляди, дві волі, дві тактики боротьби, різні інтереси» [2, с. 488]. 3 цими словами важко не погодитися.

Проблематика

допиту

представників різних молодіжних неформальних течій розглядалася в роботах таких учених-криміналістів, як I.M. Білоус, В.І. Бояров, О.М. Коршунова, В.О. Давидов, В.О. Єршов, В.С. Капіца, Г.В. Костильова,

К.В. Латиш, М.М. Мілованова, О.С. Пудовіков, Д.А. Сафонов,

О.В. Холопов, О.В. Шлегель.

Однак нині відсутні комплексні узагальнення тактико-криміналістичного забезпечення допиту підозрюваних членів молодіжних неформальних груп (об'єднань).

Метою статті $€$ визначення окремих особливостей допиту підозрюваного - члена молодіжної неформальної групи (об’єднання).

Під неформальною молоддю в контексті криміналістичного дослідження слід розуміти молодих людей (14-35 років), об'єднаних сповідуванням певних ідей, теорій, релігій або навіть прослуховуванням певної музики, проведенням вільного часу, які задля пропагування своїх поглядів, інтересів, функціонування неформального утворення вчиняють кримінальні правопорушення.

Неодмінною умовою проведення допиту підозрюваного-неформала $\epsilon$ підготовка до нього [3, с. 86-87], яка може займати до декількох днів та має бути вкрай ретельною. Слідчий (прокурор) повинен максимально повно ознайомитися 3 біографією підозрюваного (зокрема, мати психологічний портрет підозрюваного), специфікою, структурою молодіжної неформальної групи (об’єднання), до якої він входить, його місцем у ній. Може виникнути потреба консультування зі спеціалістом, який вивчає діяльність різних молодіжних неформальних утворень. Так, анкетування слідчих показало, що вони жодного разу не користувалися допомогою зазначеного спеціаліста під час підготовки до допиту. Сама ж підготовка здійснювалися лише у $67 \%$ випадків.

Великого значення під час підготовки до допиту підозрюваного члена молодіжної неформальної групи (об'єднання) набуває цілеспрямоване вивчення матеріалів кримінального провадження, яке передбачає предметну систематизацію матеріалів про факти, події, особу тощо; виявлення суперечностей та прогалин у досліджуваних матеріалах; одержання контрольних відомостей, які можна використовувати на допиті [4, с. 334-335].

$$
\text { В.А. Журавель справедливо }
$$

зазначає, що інформаційний обмін між допитуваним i допитуючим не $\epsilon$ безмежним, а зумовлений та конкретизується предметом допиту [5, c. 17]. Коло тих обставин, які слідчий має намір з'ясувати шляхом допиту, називається предметом допиту [6, с. 188]. Умовно ці обставини можна розділити на такі три групи: ті, що стосуються особи підозрюваного; ті, що стосуються вчинення 
правопорушення (злочину); ті, що стосуються існування та функціонування молодіжної неформальної групи (об'єднання). Задля встановлення відповідних обставин та безпосереднього контактування 3 підозрюваним, який належить до неформального утворення, слідчому (прокурору) необхідно розробити перелік запитань, що мають бути поставлені та можуть коригуватися, уточнятися безпосередньо під час допиту. Окрім цього, виваженим має бути підхід до вибору тактичних прийомів (тактичних комбінацій), що можуть бути використані. Як правило, допит підозрюваного-неформала відбувається в конфліктній ситуації, тому тактика допиту може бути побудована на використанні даних про особу підозрюваного 3 активізацією його позитивних якостей (зокрема, тоді, коли підозрюваний $є$ неповнолітнім); роз'ясненні йому позитивних наслідків співпраці зі слідством, наявних компромісних процедур. Для встановлення психологічного контакту слідчий використовує допомогу спеціалістів-психологів тощо [7, с. 253]. Результати анкетування слідчих свідчать про те, що лише в $11 \%$ випадків під час допиту підозрюваного - члена молодіжної неформальної групи (об'єднання) використовувалася допомога спеціаліста-психолога, що не може не викликати певну стурбованість.

Також ефективним тактичним прийомом, за допомогою якого слідчий отримує від підозрюваного правдиві показання, $\epsilon$ використання вже під час допиту показань співучасників; інформації, отриманої в процесі обшуків, допитів свідків та потерпілих; даних 3 мережі Інтернет, камер зовнішнього відеоспостереження тощо [7, с. 253].

М.М. Букаєв та Ж.В. Вассалатій, досліджуючи злочини терористичного характеру, які можуть вчинятися представниками різних молодіжних неформальних утворень, наголошують на доцільності застосування під час допитів тієї переваги, що члени злочинної групи ізольовані один від одного. У цій ситуації, як правило, обирається найбільш психологічно слабкий учасник (наприклад, наймолодший або той, хто має слабкий характер). При цьому слідчий може оголосити показання інших учасників, у яких містяться відомості про те, що допитуваний $\epsilon$ організатором злочину. У відповідь нерідко підозрюваний може назвати справжнього лідера групи [8, с. 121].

Якщо ж під час допиту підозрюваний «замикається» і не бажає відповідати на запитання слідчого (прокурора), то може бути застосований такий тактичний прийом, як провокація поглядів підозрюваного. Метою цього тактичного прийому $\epsilon$ встановлення наявності певних поглядів, переконань підозрюваного. Під час допиту необхідно створити ситуацію, за якої виникне дискусія, й «зачепити» підозрюваного (слідчий може виказати незадоволеність політикою держави, культурним рівнем іноземців, не погодитися 3 якимось поглядами потерпілого, зазначити, що дотримується таких само релігійних переконань або вболіває за той самий футбольний клуб). Це може викликати емоційний сплеск у підозрюваного та змусить його висловити свою точку зору, що дасть змогу слідчому, зрештою, отримати необхідну інформацію, оскільки, захопившись розмовою, тим, що його дійсно бентежить, допитуваний перестане себе контролювати й розповість про реальні мотиви своєї поведінки та своїх вчинків.

У ході допиту підозрюваного члена молодіжної неформальної групи (об'єднання), особливо тоді, коли він є конфліктним, слідчий (прокурор) має передбачити тактичні ризики, які можуть ускладнити або взагалі звести нанівець усю виконану роботу.

Такими тактичними ризиками можуть бути небажання підозрюваного йти на контакт зі слідством, як наслідок, відмова давати будь-які показання; намагання заплутати, обманути особу, що допитує; спроба здійснення психологічного впливу (погрози, 
залякування) на слідчого (прокурора); спроба втечі під час допиту (з кабінету слідчого, прокурора, під час допиту на місці подіі).

Отже, запропоновані рекомендації мають сприяти тактично грамотному проведенню допиту підозрюваного - члена молодіжної неформальної групи (об'єднання) та полегшити процес підготовки до нього, адже саме результати допиту підозрюваного (підозрюваних) можуть суттєво вплинути на подальший хід розслідування.

\section{Література}

1. Андросюк В. Г. та ін. Психологія слідчої діяльності : навчальний посібник / за заг. ред. Л. І. Казміренко. Київ : Правова єдність, 2009. 200 с.

2. Васильев В.Л. Юридическая психология : учебник для вузов. 5-е изд., доп. и перераб. Санкт-Петербург : Питер, 2008. 656 с.

3. Ларкін М. О. Підготовка до допиту підозрюваного - члена молодіжної неформальної групи (об’єднання). Кримінальне провадження: новації процесуальної теорії та криміналістичної практики : матеріали міжнародної науково-практичної конференції (18-19 квітня 2013 року, м. Сімферополь, Алушта; Таврійський національний університет імені В.І. Вернадського). Сімферополь : ДІАЙПІ, 2013. C. $86-87$.

4. Шепітько В. Ю. та ін. Криміналістика : підручник : у 2 т. Харків : Право, 2019. Т. 1. $456 \mathrm{c}$.

5. Журавель В. А. Допрос потерпевшего и использование его показаний для построения методики расследования отдельных видов преступлений : автореф. дисс. ... канд. юрид. наук : спец. 12.00.09. Харьков, 1983. 17 с.

6. Шепітько В. Ю. та ін. Криміналістика : підручник. 4-е вид., перероб. і доп. Харків : Право, 2008. 464 с.

7. Бояров В. І. Особливості допиту підозрюваних у кримінальних провадженнях про екстремістську діяльність. Підприємництво, господарство $i$ право. 2017. № 5. C. 251-254.

8. Букаев Н. М., Вассалатий Ж. В. Методика расследования преступлений террористического характера : монография. Москва : Юрлитинформ, 2010. 160 с.

\section{References}

1. Androsiuk, V. H. et al. (2009), Psykholohiia slidchoi diialnosti: navchalnyi posibnyk [Psychology of investigative activity: a tutorial], Pravova yednist, Kyiv, Ukraine.

2. Vasylev, V. L. (2008), Yurydycheskaia psykholohyia: uchebnyk dlia vuzov [Legal psychology: high school textbook], Pyter, Sankt-Peterburh, Russia.

3. Larkin, M. A. (2013), "Preparation for interrogation of a suspect - a member of a youth informal group (association)", Kryminalne provadzhennia: novatsii protsesualnoi teorii ta kryminalistychnoi praktyky: materialy mizhnarodnoi naukovo-praktychnoi konferentsii], Simferopol, DIAIPI, May 18-19, 2013, pp. 86-87.

4. Shepitko, V. Yu. et al. (2019), Kryminalistyka: pidruchnyk [Criminalistics: high school textbook], Pravo, Kharkiv, Ukraine.

5. Zhuravel, V. A. (1983), "Interrogation of the victim and the use of his testimony to build methods of investigation of certain types of crimes", Thesis abstract for Cand. Sc. (Criminalistics.), 12.00.09, Kharkov, Ukrainian SSR. 
6. Shepitko, V. Yu. et al. (2008), Kryminalistyka: pidruchnyk [Criminalistics: high school textbook], Pravo, Kharkiv, Ukraine.

7. Boiarov, V. I. (2017), "Features of interrogation of suspects in criminal proceedings about extremist activity". Pidpryiemnytstvo, hospodarstvo i pravo, vol. 5, pp. 251-254.

8. Bukaev, N. M. et al. (2010), Metodyka rassledovanyia prestuplenyi terrorystycheskoho kharaktera : monohrafyia [The methods of investigation of crimes of a terrorist nature : monograph], "Iurlytynform", Moskva, Russia.

УДК 378.4-049.5

DOI https://doi.org/10.26661/2616-9444-2019-2-11

\section{Внутрішні та зовнішні загрози безпеці діяльності вищого навчального закладу: теоретичні та практичні аспекти}

Мельковський О. В.

Запорізькій національний університет, вул. Жуковського, 66, м. Запоріжжя, Украӥна av-melkovskiy@ukr.net

\section{Ключові слова:}

система безпеки, внутрішні та зовнішні загрози, терористичні акти, надзвичайні події, техногенні катастрофи, запобіжні заходи, кримінальні прояви, економічна безпека, ризики безпеки.
У статті здійснено аналіз проблем розвитку та функціонування системи безпеки вищого навчального закладу в умовах сучасних ризиків. Розглянуто пропозиції щодо вдосконалення системи безпеки, запропоновано шляхи іiі реалізації 3 використанням практичних рекомендацій. Розглянуто структуру економічного потенціалу вищого навчального закладу та інші проблемні питання забезпечення економічної безпеки.

Надійшло до редколегії:

19.08.2019

Прийнято до друку: 27.09.2019

\section{Internal and external threats to safety of activity of higher educational establishment: theoretical and practical aspects}

\section{Melkovskiy O. V.}

Zaporizhzhia National University, str. Zhukovskoho, 66, Zaporizhzhia, Ukraine av-melkovskiy@ukr.net

Key words: security system, internal and external threats, terrorist acts, extraordinary events, man-made disasters, preventive measures, criminal manifestations, economic security, security risks.
Higher educational establishment is the basic brunch of the system of recreation of public intellect and state elite, acquisition and distribution of new knowledge, preparation and retraining of staff. In the conditions of development of any state there is a necessity of improvement of quality of higher education.

Nowadays the native system of higher education is currently functioning under the terms of complex system calls, the main of which should include the following: shortage of entrants, connected with the demographic collapse of the late 1980-s - early 1990-s; 
transition to the level system of education, which leads to a decrease in the volume of funding of higher education institutions; increased competitive rivalry in the market of higher education services; outflow of entrants from regions to universities of the capital cities and educational establishments of other states.

Taking into account international practice, it is possible to identify the key threats encountered by most educational establishments, namely:

1) terrorist acts,

2) fires, extraordinary events, man-made disasters,

3) acts of violence by third parties (mentally ill, those who are in the state of alcohol or narcotic intoxication),

4) criminal manifestations (theft, extortion, drug distribution),

5) internal conflicts between persons study or with teachers.

In order to ensure the safety of the higher educational establishment, the following tactical tasks must be implemented:

1) develop security policy of the educational establishment;

2) develop regulations on the security of the establishment;

3) create own security service or conclude an agreement with the security organization;

4) create posts of physical protection on key areas in the educational establishment;

5) implement control regime;

6) implement a system of access control and access management, integrating into it electronic student (pupil) tickets;

7) equip the educational institution with modern systems of security and fire alarm, video surveillance, video analytics and registration.

Вищий навчальний заклад $\epsilon$ основною ланкою системи відтворення громадського інтелекту та державної еліти, отримання й поширення нових знань, підготовки та перепідготовки кадрів. В умовах розвитку будь-якої держави виникає потреба підвищення якості вищої освіти.

Вітчизняна система вищої освіти сьогодні функціонуе в умовах дії комплексу системних викликів, до основних з яких слід віднести:

$$
\text { - дефіцит }
$$

абітурієнтів,

пов'язаний з демографічним спадом кінця 1980-х - початку 1990-х років;

- перехід на рівневу систему освіти, що приводить до зниження обсягів фінансування вищих навчальних закладів;

\section{- посилення конкурентного}

суперництва на ринку послуг вищої освіти, відтік абітурієнтів з регіонів до
ВН3 столичних міст та навчальних закладів інших держав.

У сучасному світі питання створення системи безпеки у навчальних закладах $€$ досить актуальними. Інформація, що надходить зі ЗМІ про випадки безпрецедентної жорстокості по відношенню до учнів i персоналу як 3 боку терористів і кримінальних елементів, так і з боку самих учнів, іноді шокує.

Численні випадки, наприклад масові вбивства в школах і ВНЗ США, Росії та низки інших держав світу, вимагає професійного аналізу стану системи забезпечення безпеки навчальних закладів. У сучасний період Україна намагається стати активною частиною європейського та світового товариства, у зв'язку з чим зазначені проблеми $\epsilon$ актуальними для нашої держави.

3 урахуванням міжнародної практики можна визначити ключові 
загрози, 3 якими стикається більшість навчальних закладів. Отже, ними є:

- терористичні акти;

- пожежі, надзвичайні події, техногенні катастрофи;

- акти насильства 3 боку третіх осіб (психічно хворих, таких, що перебувають у стані алкогольного або наркотичного сп'яніння);

- кримінальні

прояви

(розкрадання, вимагання, поширення наркотичних речовин);

- внутрішні конфлікти між особами, що навчаються, або 3 викладачами.

При цьому статистика свідчить про те, що 90\% проблем, пов'язаних 3 безпекою у навчальних закладах, викликані особами, що навчаються, i лише 10\% - сторонніми особами.

Аналізуючи міжнародний досвід забезпечення безпеки навчальних закладів, зазначаємо, що у більшості країн цьому питанню приділяється особлива увага. Найбільш серйозний підхід до питань забезпечення безпеки існує у США.

Після трагедіï 11 вересня 2001 року були створені національні програми комплексної підготовки у сфері безпеки, які включають роботу не тільки 3 охоронцями навчальних закладів, але й 3 батьками, учнями, викладачами та співробітниками. Усі, хто так чи інакше належить до навчального процесу, повинні вміти розпізнавати тривожні сигнали в поведінці учнів, знати, куди можна звернутися по допомогу.

При цьому є досить вагомою діяльність психологічних служб, зобов'язаних створити умови, за яких особи, які страждають на психічні відхилення, не почувалися б відірваними від суспільства.

Крім того, учнів захищають не тільки від загрози нападу терористами, пожеж або крадіжок, але й від самих себе. Як правило, в районах 3 небезпечною криміногенною ситуацією кожен вхід до будівлі навчального закладу обладнаний кулезахисним пунктом 3 металошукачем, чергують поліцейські, а учні контрольовано, один за одним проходять на уроки.

Якщо навчальний заклад розташований в тихому районі (або фешенебельному, як Беверлі Хіллз), то правила безпеки для учнів тут помітно знижені. Працюють кілька охоронців, які регулярно пересуваються шкільною будівлею та прилеглою територією, а допомагає їм контролювати ситуацію мережа відеокамер. За відеокамерами оператори стежать переважно в нічний час.

Після декількох трагічних випадків була переглянута політика безпеки в навчальних закладів Китаю. Зокрема, керівники народної освіти 14 провінцій, регіонів та муніципальних утворень провели конференції для обговорення шляхів підвищення безпеки. Старші посадові особи Пекіна, Тяньцзіня, Тибету, Хебей, Хубей, Шаньдун, Хенаня й багатьох інших областей та регіонів періодично особисто інспектують місцеві навчальні заклади й перевіряють, які заходи безпеки вжито. Крім того, створюються постійно діючі робочі комітети, що стежать за станом безпеки в школах i дитячих садах. Провінційні уряди вирішили направити більше поліцейських патрулів до шкіл для цілодобової перевірки документів.

Деякі великі міста вжили ще жорсткіших заходів. У Чунціні, на південному заході Китаю, в школах i дитячих садках цілодобово перебувають професійні охоронці 3 кийками, наручниками й балончиками 3 перцевим газом. У багатьох провінційних столицях, відповідно до заяв муніципальних органів влади, посилені заходи безпеки, встановлені відеокамери, охоронці забезпечені більш досконалим устаткуванням.

Разом 3 кримінальними загрозами велика увага в навчальних закладах передових держав світу приділяється пожежній безпеці. Так, за європейськими та американськими стандартами будівля 
школи повинна мати не більше двох поверхів. На випадок пожежі ця вимога полегшить евакуацію дітей i доступ пожежників до палаючих приміщень.

Крім цього, школи обов'язково повинні бути оснащені системами пожежної сигналізації, а іноді пристроями автоматичного гасіння вогню.

Водночас у пострадянських країнах, де рівень загроз традиційно високий, безпеці навчальних закладів не приділяється достатньої уваги.

Аналогічна ситуація склалася в Російській Федерації, де, незважаючи на неодноразові випадки кримінальних i терористичних посягань на учнів, питання безпеки навчального закладу залишається в компетенції його керівника.

Аналізуючи ситуацію в Республіці Молдова, ми можемо дійти невтішних висновків про те, що безпеці навчальних закладів не приділяється увага. Зокрема, не існує єдиної політики безпеки в цій галузі. Більшість шкіл і ВНЗ вирішує це питання за рахунок позабюджетних коштів, при цьому рівень підготовки осіб, зайнятих у сфері забезпечення безпеки, залишає бажати кращого.

Аналогічна ситуація існує в Україні. На практиці наявність сучасних систем охоронно-пожежної сигналізації, відеоспостереження та інших охоронних системи $\epsilon$ скоріше виключенням, ніж правилом, тому це питання обов'язково має розглядатися на рівні Міністерства освіти і науки, а навчальні заклади мають бути забезпечені фізичною охороною за рахунок державного бюджету.

Задля забезпечення безпеки навчальних закладів необхідно реалізувати такі тактичні завдання:

1) розробити політику безпеки навчального закладу;

2) виробити положення про безпеку навчального закладу;

3) створити власну службу безпеки або укласти договір 3 охоронною організацією;
4) створити пости фізичної охорони на ключових ділянках у навчальному закладі;

5) реалізувати

контрольнопропускний режим;

6) впровадити систему контролю й управління доступом шляхом інтегрування в неї електронних студентських (учнівських) квитків;

7) встановити

системи відеоспостереження та реєстрації, оснащені системами відеоаналітики;

8) оснастити навчальний заклад сучасними системами охоронно-пожежної сигналізації.

Охорона навчальних закладів - це складний комплекс заходів, який повинні організовувати тільки професійні охоронні компанії, де підібраний професійний склад працівників.

Впровадження комплексної системи безпеки в навчальних закладах має цілий комплекс технічних рішень. Задля цього реалізується технічна система контролю й управління доступом (СКУД), яка включає обмеження доступу до навчального закладу тільки авторизованими особами за спеціальними ключ-картами. Студенти отримують ідентифікаційну картку (на ній записані інформація про особу й телефон навчального закладу, за яким можна зв'язатися в разі будь-якої події). Одночасно картка $\epsilon$ пропуском для доступу до навчального закладу.

Завдяки цій системі застосування подібних карт дасть змогу вести облік відвідування студентів, зокрема формувати спеціальну електронну базу, доступ до якої віддалено за спеціальним паролем зможуть отримувати батьки.

Запобіжним заходом $\epsilon$ встановлення на вході до навчального закладу системи рентгеноскопічного контролю, яка допоможе виявити зброю в осіб, що мають намір іï використання. Устаткування для рентгеноскопічного контролю випускається в портативному варіанті, пристосованому для використання в маленьких приміщеннях, а 
також вузьких коридорах i дверних отворах. Огляд може проводити як співробітник охорони, так і підготовлений співробітник навчального закладу. Водночас можуть застосовуватися арочні металодетектори.

Наступним рівнем системи безпеки $€$ відеоспостереження. Ці системи налаштовані таким чином, що дають змогу камерам, розташованим у різних місцях, одночасно передавати відеозображення співробітникам служб екстреного реагування прямо в патрульні автомобілі, що забезпечує швидке й ефективне реагування патрульних екіпажів на складну ситуацію. Камери нічного бачення широко використовуються, наприклад, в американських школах i дають змогу співробітникам охорони спостерігати за тим, що відбувається в школі після закінчення занять.

Разом 3 інфрачервоною камерою системи нічного бачення забезпечують відеоспостереження за периметром навчального закладу незалежно від розмірів і погодних умов. Використання камер відеоспостереження в навчальних закладах має деяку специфіку. Як спосіб запобігання злочинам відеозйомка дає змогу ефективно боротися 3 крадіжками та вандалізмом. Встановлені камери повинні бути вандалостійкими, мати вбудований механізм, що дає змогу автоматично виявляти вандалізм за допомогою сигналу тривоги, який подається в разі закриття або переміщення камери.

Особливо

застосування відеоаналітики, налаштовувати відеоспостереження під різні завдання. Наприклад, за допомогою подібних алгоритмів можна визначати у великих аудиторіях студентів, які списують.

Крім того, сучасні системи відеоспостереження завдяки дистанційному виміру температури тіла можуть визначати серед потоку осіб, що прибувають до навчального закладу хворими.

Якщо для надійного запобігання й контролю наявних загроз фізичної присутності охоронця не вистачає або воно неможливо, в навчальному закладі може бути використана система дистанційного контролю. Сигнали, що надходять 3 відеокамер під час виявлення об'єктів, які рухаються, записуються, підтверджуються й надходять у центр віддаленого відеоконтролю, де оператор аналізує ситуацію й приймає рішення щодо ії локалізації.

Нині існують спеціальні програми, за допомогою яких служби екстреного реагування можуть швидко ознайомитися 3 поверховими планами та фотографіями будівлі, шляхами евакуації, приміщеннями, в яких зберігаються небезпечні матеріали, оцінити обстановку й визначити місце зосередження спецтехніки.

Таким чином, співробітники служб екстреного реагування матимуть уявлення про об'єкт, коли прибудуть на місце події. Це особливо важливо в навчальних закладах, оскільки вони, як правило, розташовуються у великих будинках 3 великою кількістю приміщень, кабінетів.

Завершує комплекс основних заходів безпеки «тривожна кнопка» для екстреного зв'язку 3 підрозділами Національної поліції, встановлена у співробітника охорони та чергового.

Перехід до ринкових відносин i загострення конкурентної боротьби між ВНЗ привели до необхідності посилення уваги до проблеми економічної безпеки, під якою розуміється економічна захищеність ВН3 та інтересів його працівників від зовнішніх i внутрішніх загроз, що дає змогу зберегти та ефективно використати свій економічний потенціал.

Економічний потенціал, що формується у ВН3, визначається сукупністю та рівнем розвитку таких факторів: 
- кадровий потенціал, який здійснює освітню й науково-дослідну діяльність;

- матеріально-технічна база, перш за все забезпечення виробничими площами;

- соціальна база як одна 3 умов підтримки працездатності та стабілізації трудового колективу;

- організаційно-економічний

механізм управління ВН3 та фінансовими потоками;

- результативність фінансовоекономічної діяльності.

Розгляд структури економічного потенціалу ВНЗ дає змогу визначити основні напрями забезпечення економічної безпеки. До них належать:

- розвиток інтелектуальновиробничого потенціалу, який здійснює освітню й науково-дослідну діяльність;

- ресурсозабезпечення, що включає стан власних виробничих площ, оснащення лабораторій необхідним обладнанням, їх збереження й розвиток;

- наявність соціальної бази та ефективність її використання;

- управлінська діяльність (те, які управлінські рішення щодо економічної безпеки будуть, прийняті керівництвом ВH3);

$\begin{array}{ccc}- & \text { економічна } & \text { ефективність } \\ \text { діяльності } & \text { ВН3, що } & \text { оцінюється }\end{array}$ фінансовим результатом та ефективністю використання економічних ресурсів, власних i залучених коштів, а також виконанням фінансових зобов'язань.

Загалом можна виділити такі фактори формування загроз економічній безпеці будь-якого ВНЗ:

- політичні фактори (загальна політична ситуація в країні);

$\begin{array}{rcr}- & \text { демографічні та } \\ \text { фактори } & \text { (зменшення } & \text { чисельнольні }\end{array}$ місцевого населення в регіоні або державі);

- правові фактори (наявність правового забезпечення системи вищої освіти);
- соціально-культурні

та

морально-етичні фактори (загальний запит суспільства на привабливість вищої освіти);

- фінансово-економічні фактори (наявність економічної можливості населення на отримання вищої освіти).

Для створення механізмів запобігання негативним наслідкам впливу різних факторів на економічний стан вищої освіти необхідне їх детальне вивчення.

Необхідним $\epsilon$ розроблення інструментарію оцінювання, моніторингу та забезпечення економічної безпеки, причому сама категорія «економічна безпека господарюючого суб'єкта» повинна визначатися 3 урахуванням специфіки функціонування цього господарюючого суб'єкта. Стосовно вищого навчального закладу економічна безпека трактується як економічна захищеність ВНЗ та інтересів його працівників від зовнішніх і внутрішніх загроз, що дає змогу зберегти й ефективно використовувати свій економічний потенціал.

Під загрозою тут розуміються зміни в зовнішніх та внутрішніх компонентах середовища функціонування господарюючого суб'єкта, які можуть привести до таких змін, що проблематичним стануть функціонування й навіть існування суб'єкта.

Деякі науковці визначають економічну безпеку освітнього закладу як стан наявності необхідних ресурсів i системи взаємовідносин між агентами ресурсообігу, що дають змогу якісно здійснювати функції організації та створюють стан іiі захищеності в економічних, соціальних i політичних умовах.

Очевидно, що для забезпечення високого рівня економічної безпеки й підтримання вищого навчального закладу в нормальному стані необхідна об'єктивна й оперативна інформація про зміни, що відбуваються в керованому об'єкті. У зв'язку 3 цим необхідно організувати 
систему регулярного моніторингу, що надає менеджерам ВН3 релевантну інформацію для прийняття своєчасних та ефективних управлінських рішень, пов'язаних із забезпеченням економічної безпеки.

Отже, проблема економічної безпеки ВНЗ у сучасних умовах набуває особливої актуальності. Цьому сприяють економічна нестабільність суспільства, скорочення бюджетного фінансування низки ВНЗ, незрозумілість умов виживання за відсутності бюджетного фінансування, недосконалість законодавства (зокрема, розбіжність нормативних правил податкового та бюджетного обліку), відсутність механізму страхування ризику прийняття управлінських рішень у сфері освіти, різноспрямованість інтересів традиційно наявних у ВНЗ структурних підрозділів, наявність утриманських настроїв у працівників.

Проблема забезпечення безпеки вищих навчальних закладів зараз є досить актуальною, оскільки число небезпек i загроз регулярно зростає, таких як тероризм, пожежі, кримінальні дії окремих осіб, економічна конкуренція. Рівень забезпечення безпеки більшості вищих навчальних закладів перебуває на вкрай низькому рівні й вимагає модернізації. Основною проблемою $\epsilon$ відсутність єдиної політики в цьому питанні, а також недостатня увага відповідних державних органів. Задля підвищення безпеки вищих навчальних закладів слід вжити комплексних заходів безпеки, які включать як встановлення постів фізичної охорони, так i застосування сучасних технічних засобів безпеки. Це дасть змогу звести до мінімуму число можливих негативних проявів щодо студентів та працівників ВН3. У сучасних умовах питання економічної безпеки мають бути основними у зв'язку 3 тим, що економічний стан будь якої структури держави $є$ головним фактором загальної стабільності та забезпечення системи безпеки, зокрема ВНЗ.

\section{Втручання в діяльність судових органів як спроба посягання на принцип незалежності судової гілки влади в Україні}

\section{Сінсльнік Р. В.}

Запорізький національний університет, вул. Жуковського, 66, м. Запоріжюся, Украӥна ruslan_sinelnik@ukr.net

\section{Ключові слова:}

судова влада, суддя, правосуддя, незалежність, недоторканність, втручання в діяльність судових органів.

Надійшло до редколегії: 19.09.2019

Прийнято до друку: 28.10.2019
У статті розглянуто вплив реформаційних процесів у сфері судової влади України на втручання у діяльність судових органів. Автором проаналізовано засади судочинства, засади забезпечення незалежності судді, акцентовано увагу на важливості дотримання принципів незалежності та недоторканності судді. Наведено приклади категорій ситуацій, описаних у повідомленнях суддів про втручання в їхню діяльність, розглянутих Вищою радою правосуддя. Здійснено дослідження правових способів захисту від протиправного впливу на неупередженість носіїв судової влади. Автор розкриває наслідки скоєння злочинів проти правосуддя, обгрунтовує їх вплив на процес судового розгляду справи та 
винесення справедливого рішення, незалежність судової влади, а також рівень довіри громадян до суду.

\title{
Intervention in the activities of judicial authorities how to take achievement of the independence of the judicial branch of power in Ukraine
}

Sinielnik R. V.

\author{
Zaporizhzhya National University, str. Zhukovskogo, 66, Zaporizhzhya, Ukraine \\ ruslan_sinelnik@ukr.net
}

Key words: judiciary, judge, justice, independence, inviolability, interference with the activities of the judiciary.

The article deals with the influence of the reform processes in the sphere of the judicial power of Ukraine on the interference with the activity of the judicial bodies. The author analyzes the principles of the judiciary, the principles of ensuring the independence of the judge, and emphasizes the importance of observing the principles of independence and integrity of the judge Examples of the categories of situations described in the Judges' reports of interference with their activities were reviewed by the High Judicial Council. The legal ways of protection against unlawful influence on the impartiality of the judiciary are carried out.

Guaranteeing the independence of the judiciary in our country is a pledge of fair and impartial administration of justice. The Basic Law of Ukraine stipulates that the independence and integrity of a judge are guaranteed by the Constitution and laws of Ukraine. The judge, in the administration of justice, is independent and governed by the rule of law.

Unfortunately, despite numerous reforms process in the judiciary, every year the interference in judges is not terminated, but rather becomes threatening and is the basis for the consideration of the High Council of Justice reports of interference in judicial activities concerning the administration of justice. In particular, interference with the work of judges is carried out by law enforcement agencies, citizens and their associations, the media, and often by lawyers.

On the way to Ukraine to ensure the independence of the judiciary, rule of law, the right to a fair trial and authorized in accordance with European standards of justice priority is to resolve on combating crime against justice and personal security of life and health carriers judiciary, members of their families and their homes and property.

Гарантія незалежності судової гілки влади у нашій державі є запорукою справедливого та неупередженого відправлення правосуддя. Основним Законом України передбачено, що незалежність i недоторканність судді гарантуються Конституцією та законами України. Суддя, здійснюючи правосуддя, $\epsilon$ незалежним та керується верховенством права [3].

Стаття 129 Конституції України
визначає, що основними засадами

судочинства $є$ такі:

1) рівність усіх учасників судового процесу перед законом і судом;

2) забезпечення доведеності вини;

3) змагальність сторін та свобода щодо надання ними суду своїх доказів і доведення перед судом їх переконливості;

4) підтримання публічного обвинувачення в суді прокурором;

5) забезпечення обвинуваченому права на захист;

6) гласність судового процесу та 
його повне фіксування технічними засобами;

7) розумні строки розгляду справи судом;

8) забезпечення права на апеляційний перегляд справи, a y визначених законом випадках - на касаційне оскарження судового рішення;

9) обов'язковість судового рішення.

Законом можуть бути визначені також інші засади судочинства.

Судочинство провадиться суддею одноособово, колегією суддів чи судом присяжних. За неповагу до суду чи судді винні особи притягаються до юридичної відповідальності [3].

Норма статті 126 Конституції України чітко визначає, що вплив на суддю у будь-який спосіб забороняється [3].

У 2004 році Конституційний Суд України у своєму рішенні про офіційне тлумачення положення частини першої статті 126 Конституції України (254к/96ВР) визначив, що незалежність i недоторканність суддів гарантуються Конституцією та законами України у взаємозв'язку 3 іншими положеннями розділу VIII Основного Закону України, а також вирішив, що незалежність суддів $\epsilon$ невід'ємною складовою їхнього статусу. Вона $€$ конституційним принципом організації та функціонування судів, а також професійної діяльності суддів, які, здійснюючи правосуддя, підкоряються лише закону. Незалежність суддів забезпечується насамперед особливим порядком їх обрання або призначення на посаду та звільнення з посади; забороною будь-якого впливу на суддів; захистом їх професійних інтересів; особливим порядком притягнення суддів до дисциплінарної відповідальності забезпеченням державою особистої безпеки суддів та їхніх сімей; гарантуванням фінансування та належних умов для функціонування судів i діяльності суддів, їх правового та соціального захисту; забороною суддям належати до політичних партій та профспілок, брати участь у будь-якій політичній діяльності, мати представницький мандат, займатися за сумісництвом певними видами діяльності; притягненням до юридичної відповідальності винних осіб за неповагу до суддів і суду; суддівським самоврядуванням [7].

Недоторканність суддів - це один iз елементів їхнього статусу. Вона не $є$ особистим привілеєм, а має публічноправове призначення, що полягає $\mathrm{y}$ забезпеченні здійснення правосуддя неупередженим, безстороннім та справедливим судом. Положення частини другої статті 126 Конституції України (254к/96-ВР) «вплив на суддів у будь-який спосіб забороняється» треба розуміти як забезпечення незалежності суддів у зв'язку зі здійсненням ними правосуддя, а також як заборону щодо суддів будь-яких дій незалежно від форми їх прояву з боку державних органів, установ та організацій, органів місцевого самоврядування, їх посадових i службових осіб, фізичних та юридичних осіб задля перешкоди виконанню суддями професійних обов'язків або схилення їх до винесення неправосудного рішення тощо [7].

Незалежність суду також закріплена у статті 6 Закону України «Про судоустрій і статус суддів» (далі - Закон). Так, частина перша статті визначає, що, здійснюючи правосуддя, суди $\epsilon$ незалежними від будь-якого незаконного впливу, суди здійснюють правосуддя на основі Конституції та законів України, а також на засадах верховенства права [2].

Відповідно до частини другої статті 6 Закону звернення до суду громадян, організацій чи посадових осіб, які, відповідно до закону, не є учасниками судового процесу, щодо розгляду конкретних справ судом не розглядаються, якщо інше не передбачено законом [2].

Iз положення частини 3 статті 6 Закону випливає, що втручання у 
здійснення правосуддя, вплив на суд або суддів у будь-який спосіб, неповага до суду чи суддів, збирання, зберігання, використання та поширення інформації усно, письмово або в інший спосіб задля дискредитації суду або впливу на безсторонність суду, заклики до невиконання судових рішень забороняються й мають наслідком відповідальність, установлену законом [2].

Частина 4 статті 6 Закону прямо відсилає до обов'язку органів державної влади та органів місцевого самоврядування, їх посадових осіб утримуватися від заяв та дій, що можуть підірвати незалежність судової влади [2].

Частина 5 статті 6 Закону визначає діяльність суддівського самоврядування як органу, на який покладено функцію захисту професійних інтересів суддів та вирішення питань внутрішньої діяльності судів [2].

Суддя як особа, наділена повноваженнями щодо здійснення правосуддя, має особливі засади незалежності, які містить стаття 48 Закону.

1) Суддя у своїй діяльності щодо здійснення правосуддя є незалежним від будь-якого незаконного впливу, тиску або втручання.

2) Суддя здійснює правосуддя на основі Конституції та законів України, керуючись принципом верховенства права. Втручання у діяльність судді щодо здійснення правосуддя забороняється й має наслідком відповідальність, установлену законом.

3) Суддя не зобов'язаний давати жодних пояснень щодо суті справ, які перебувають у його провадженні, крім випадків, установлених законом.

4) Суддя зобов'язаний звернутися 3 повідомленням про втручання в його діяльність як судді щодо здійснення правосуддя до Вищої ради правосуддя та до Генерального прокурора [2].

Отже, вплив на здійснення правосуддя в будь-якій формі здатен поставити під сумнів неупередженість судового розгляду, як наслідок, справедливість винесеного судом судового рішення в конкретній справі.

Суддя як носій судової влади, здійснюючи правосуддя відповідно до пунктів 1, 2 частини 7 статті 56 Закону, зобов'язаний справедливо, безсторонньо та своєчасно розглядати й вирішувати судові справи відповідно до закону 3 дотриманням засад і правил судочинства; дотримуватися правил суддівської етики, зокрема виявляти та підтримувати високі стандарти поведінки в будь-якій діяльності задля укріплення суспільної довіри до суду, забезпечення впевненості суспільства в чесності та непідкупності суддів [2].

В.В. Городовенко у своїх працях розрізняе зовнішню та внутрішню незалежність судової влади. Слушною $є$ його думка про те, що до зовнішньої незалежності слід відносити відокремлення судової влади від законодавчої влади та виконавчої влади; визначення незалежності (самостійності) судової влади всіма іншими гілками влади як основної та обов'язкової іiї ознаки, що полягає в неможливості існування в державі будь-яких форм стороннього впливу, політичними партіями та іншими об'єднаннями громадян, а також громадянами; законодавче закріплення незалежності суду і суддів як їі носіїв; підкорення суддів тільки закону; єдність і цілісність структури судових органів; стабільний характер формування судової системи; безстроковість повноважень суддів, їх незмінність; повнота судової влади у сфері здійснення правосуддя; виконання судових рішень всіма без винятку посадовими особами держави. Внутрішню незалежність судової влади забезпечують бездоганні особистісні якості суддів, високий професіоналізм, виключення 3 практики неправосудних судових рішень, соціально-побутові, матеріальні умови життя суддів, авторитет кожного судді як суб'єкта судової влади [9, с. 46-47]. 
Засади забезпечення незалежності судді прописані у частині 5 статті 48 Закону. Так, ними є:

- особливий

порядок

призначення судді, притягнення до відповідальності, звільнення та припинення повноважень;

$\begin{aligned} \text { судді; } & \text { недоторканність та імунітет } \\ & - \\ - & \text { незмінюваність судді; } \\ - & \text { порядок здійснення }\end{aligned}$ правосуддя, визначений процесуальним законом, таємницею ухвалення судового рішення;

- заборона втручання у здійснення правосуддя;

- відповідальність за неповагу до суду чи судді;

- окремий порядок фінансування та організаційного забезпечення діяльності судів, установленим законом;

- належне матеріальне та соціальне забезпечення судді;

- функціонування органів

суддівського врядування та самоврядування;

- визначені законом засоби забезпечення особистої безпеки судді, членів його сім'ї, майна, а також інші засоби їх правового захисту;

- $\quad$ право судді на відставку [2].

Окрім цього, Закон зобов'язує органи державної влади, органи місцевого самоврядування, їх посадових та службових осіб, а також фізичних i юридичних осіб та ї об'єднання поважати незалежність судді й не посягати на неї (частина 6 статті 48 Закону) [2].

Під час прийняття нових законів або внесення змін до чинних законів не допускається звуження змісту та обсягу визначених Конституцією України та законом гарантій незалежності судді (частина 7 статті 48 Закону) [2].

Постанова Пленуму Верховного Суду України «Про незалежність судової влади» від 13 червня 2007 року № 8 визначає, що гарантії самостійності судів та незалежності суддів в Україні належним чином не забезпечені. На практиці законодавчим органом, органами виконавчої влади, їх посадовими особами нерідко ігнорується конституційний принцип поділу влади на законодавчу, виконавчу та судову. Мають місце спроби втручання в організацію діяльності судів, вирішення конкретних судових справ, перешкоджання здійсненню судами правосуддя на визначених законом засадах, тиск на суддів шляхом погроз, шантажу та іншого протиправного впливу, зокрема, у формі прийняття незаконних нормативно-правових актів та правових актів індивідуальної дії, неправомірного використання суб' єктами влади наданих їм повноважень, а також незаконного наділення деяких державних органів відповідними повноваженнями, що посилює залежність від них судів та суддів. Останнім часом факти тиску на суддів і втручання в діяльність судів набули системного та відвертого характеру, зокрема під час розгляду судами справ, формування суддівського корпусу, призначення суддів на адміністративні посади, вирішення питань про відповідальність суддів. Грубо порушується визначений законом порядок притягнення суддів до відповідальності щодо встановлення ii підстав, строків притягнення до неї, забезпечення суддям, стосовно яких вирішується питання про відповідальність, можливості вжити передбачених законом заходів щодо свого захисту [6].

Правовим способом захисту від протиправного впливу на неупередженість носіїв судової влади, відповідно до положення пункту 9 частини 7 статті 56 Закону, є обов'язок судді звертатися 3 повідомленням про втручання в його діяльність як судді щодо здійснення правосуддя до Вищої ради правосуддя та Генерального прокурора впродовж п'яти днів після того, як йому стало відомо про таке втручання [2].

На жаль, попри численні реформаційні процеси у сфері судової влади, 3 кожним роком втручання $\mathrm{y}$ 
діяльність суддів не припиняється, а набуває загрозливого характеру та стає підставою для розгляду Вищою радою правосуддя повідомлень суддів про втручання в діяльність щодо здійснення правосуддя. Зокрема, втручання у діяльність суддів відбувається 3 боку правоохоронних органів, громадян та їх об'єднань, засобів масової інформації та нерідко з боку адвокатів.

Відповідно до інформації, яка міститься на офіційному веб-сайті Вищої ради правосуддя «Про результати діяльності Вищої ради правосуддя за 2018 рік», у 2018 році українські судді зверталися 3 повідомленнями про втручання в діяльність судді 436 разів, що на $32 \%$ більше, ніж у 2017 році (330 заяв) [14]. Ця статистика підтверджує зростання негативних явищ впливу на неупередженість судового розгляду та справедливого вирішення судового спору.

Кримінальний кодекс України (далі - ККУ) встановлює відповідальність за втручання в діяльність судових органів. Так, відповідно до статті 376 ККУ, втручанням $\epsilon$ втручання в будь-якій формі в діяльність судді задля перешкоди виконанню ним службових обов'язків або винесення неправосудного рішення; ті ж самі дії, якщо вони перешкодили запобіганню злочину чи затриманню особи, яка його вчинила, або вчинені особою 3 використанням свого службового становища [4].

Науково-практичний коментар

ККУ під втручанням розуміє вплив на свідомість і волю судді, а для кваліфікації цього діяння за статтею 376 ККУ не має значення, у який спосіб і за допомогою яких засобів здійснюється такий вплив (прохання, рекомендація, вказівка, вимога, критика судді в засобах масової інформації до вирішення справи, обіцянка всіляких вигід, залякування судді чи його близьких тощо) [13, с. 853].

Втручання може здійснюватися в усній чи письмовій формі; під час безпосереднього контакту із суддею або через посередників чи за допомогою технічних засобів; шляхом впливу на самого суддю чи його близьких. Проте склад злочину відсутній, якщо втручання в діяльність судових органів здійснюється не у формі впливу на свідомість і волю судді, а в інший спосіб (наприклад, шляхом викрадення чи знищення матеріалів справи, підміни речових доказів, примушування свідків до давання неправдивих показань). Такі дії слід кваліфікувати за відповідними статтями ККУ (наприклад, за статтями 357, 386 ККУ). Якщо втручання в діяльність судді здійснюється шляхом пропозиції чи давання йому хабаря, вчинене кваліфікується за сукупністю злочинів (за статтями 369 і 376 ККУ), бо в цих випадках шкоди зазнають два об'єкти: як діяльність державного апарату, так й інтереси правосуддя [13, с. 854].

Окрім

кримінальної відповідальності за втручання в діяльність судових органів, ККУ містить такі злочини проти правосуддя:

- погроза або насильство щодо судді, народного засідателя чи присяжного, а також щодо їх близьких родичів у зв'язку 3 їх діяльністю, пов'язаною зі здійсненням правосуддя (стаття 377);

- умисне знищення або пошкодження майна, що належить судді, народному засідателю чи присяжному або ïх близьким родичам, у зв'язку 3 їх діяльністю, пов'язаною зі здійсненням правосуддя (стаття 378);

- посягання на життя судді, народного засідателя чи присяжного у зв'язку 3 їх діяльністю, пов'язаною зі здійсненням правосуддя (стаття 379) [4].

Виключається кваліфікація як втручання в діяльність судових органів i таких дій винного, які вчинюються ним із мотивів помсти вже після виконання суддею своїх обов'язків щодо здійснення правосуддя. За інших необхідних умов такі дії можуть містити ознаки одного зі злочинів, передбачених статтями 377-379 ККУ. Проте якщо в такому разі винний не 
вчинює свої дії з помсти, а спрямовує їх на схиляння судді до зміни (призупинення, припинення, скасування, перегляду) прийнятого рішення, то вчинене слід кваліфікувати за статтею 376 ККУ [4].

Як правило, факт скоєння злочинів проти правосуддя підриває незалежність судової влади та знижує рівень довіри громадян до суду, що негативно впливає на процес судового розгляду справи та винесення справедливого рішення.

$$
\text { Цю позицію підтримує }
$$

В.В. Городовенко, який вважає, що поняття незалежності судової влади й незалежності суддів взаємопов'язані, адже говорити про незалежність суддів поза поняттям незалежності судової влади неможливо. На його думку, не може бути залежної судової влади й незалежного судді (не мається на увазі ії залежність від закону). Незалежність суддів $\epsilon$ легітимною тільки в процесуальній діяльності носіїв судової влади, під час виконання ними обов'язків зі здійснення правосуддя та не виходить за цю сферу. Таким чином, поза судом і процесуальною формою принцип незалежності судді не існує [9, с. 47].

Аналізуючи звернення суддів до ВРП із повідомленнями про втручання, експерти-правники ГО «Фундація DEJURE» виокремили такі правові позиції ВРП за категоріями відповідно до ситуацій, описаних у повідомленнях.

Звернення до суду осіб, які не $є$ учасниками судових справ, які визнано втручанням у здійснення правосуддя:

- звернення комітетів Верховної Ради (ВР) України щодо вжиття судом заходів індивідуального характеру стосовно запобігання порушення прав певної особи;

- звернення депутатів ВР, місцевих рад до суду, котрі стосуються розгляду конкретних справ, учасниками яких вони не $\epsilon$;

- дзвінки чи SMS судді, у яких висловлюються заклики прийняти певне рішення та містяться погрози.
Не визнавалося втручанням $\mathrm{y}$ рішення правосуддя:

i3 $\quad-\quad$ пвернення законодавства під час розгляду справи або звернення, у яких висловлюються непогодження з рішеннями суддів;

- звернення

громадських

організацій до суддів 3 повідомленнями про взяття на громадський контроль розгляду певної справи;

- звернення громадян, у яких суддю запрошують на зустріч для надання пояснень щодо вже прийнятого ним рішення.

Звернення до суду осіб, які беруть участь у судовій справі, які не визнавалися втручанням у рішення правосуддя:

- заявлення судді відводів, зокрема безпідставних;

- звернення до суду з проханням вжити організаційних заходів щодо призначення справи до розгляду;

- звернення до голови суду із заявою про передачу справи на розгляд іншій колегії суду;

- звернення, у яких відображено ставлення учасника справи до судді чи ходу провадження у справі;

- клопотання про відкладення судового розгляду у зв'язку 3 участю особи в тестуванні в межах конкурсу на посаду в Національному антикорупційному бюро України (НАБУ);

- звернення сторони у справі до судді по мобільному телефону 3 проханням об'єктивно розглядати справу, що перебуває у провадженні;

- звернення присяжного до судді 3 проханням прийняти рішення на користь сторони у справі;

- дзвінки/SMS на мобільний телефон судді з проханнями допомогти у вирішенні судової справи, що перебуває у провадженні іншого судді того ж суду;

- спроба захисника сторони потрапити до голови суду, який здійснює провадження в його справі, на прийом 3 відмовою назватися. 
Поведінка у залі судових засідань, яка визнана втручанням у здійснення правосуддя:

- блокування залів судових засідань/приміщень судів;

- акт фізичного насильства щодо судді, пов'язаного 3 iï рішенням у нерозглянутій справі;

- заявлення відводів суддям під загрозою бойкоту судових засідань у разі їх незадоволення;

- порушення правил поведінки в судовому засіданні (висловлювання негативного характеру стосовно особи судді, нахабна поведінка, ігнорування вимог головуючого, безперервне заявлення безпідставних клопотань тощо); - постійна згадка учасників у справі про те, що вони подали заяву про вчинення злочину/дисциплінарну скаргу щодо суддів.

Звернення учасників судових справ до державних органів щодо суддів, що не визнавалося втручанням у рішення правосуддя:

- звернення 3 дисциплінарними скаргами до Вищої ради правосуддя щодо суддів;

- $\quad$ звернення із заявами до органів правопорядку щодо вчинення злочинів суддями;

- відносини суддів 3 іншими державними органами.

Визнано втручанням у здійснення правосуддя:

- звернення народного депутата до ВРП з дисциплінарною скаргою щодо судді без достатніх на те підстав;

- відкриття кримінального провадження щодо судді на підставі частини 1 статті 375 КК України як реакція на повернення суддею клопотання слідчого без розгляду;

- системний допит судді як свідка щодо справи, яка перебуває у його провадженні;

- обшук житла/кабінету судді у час, який збігається 3 часом розгляду суддею справи, пов'язаної з органом або посадовими особами органу, який здійснює обшук;

- $\quad$ тривале здійснення досудового розслідування за фактом вчинення суддею кримінального правопорушення без повідомлення останньому про підозру;

- виклик судді на допит як свідка у кримінальному провадженні щодо винесення ним завідомо неправосудного рішення через тривалий час після відкриття провадження;

- витребування від судді пояснень щодо невиконання суддею вимог норм законодавства про самовідвід у нерозглянутій справі.

$\mathrm{He}$ визнавалося втручанням у рішення правосуддя:

- надсилання прокуратурою до суду запиту щодо перебування в його провадженні певних нерозглянутих справ;

- вилучення детективами в процесі обшуку в кабінеті судді матеріалів справи, дозвіл на вилучення яких не надавався ухвалою слідчого судді;

- внесення

органами

правопорядку відомостей в Сдиний реєстр досудових розслідувань (СРДР) щодо вчинення суддею злочину, передбаченого статтею 375 КК України за заявами громадян;

- вручення судді протоколів про вчинення корупційних адміністративних правопорушень щодо дій судді в уже розглянутій справі;

- відкриття провадження за позовом особи до судді про скасування постанови про притягнення до адміністративного правопорушення (неповага до суду).

Публічні мітинги перед судом, які визнано втручанням у здійснення правосуддя:

- проведення тривалої масової акції з використанням гучної музики біля приміщення суду.

$\mathrm{He}$ визнавалося втручанням у рішення правосуддя:

- проведення

членами громадської організації акцій протесту 
біля приміщення суду.

Публікації щодо суддів у ЗМІ та Інтернеті, які не визнавалися втручанням у рішення правосуддя:

- публікації

про можливе

вчинення суддею неправомірних дій/правопорушень;

- критика професійної діяльності судді та прийнятих ним рішень;

- недобросовісне використання контактних даних судді.

Види втручання, про які в рішеннях ВРП не йдеться, а мало би:

- тиск голів судів на суддів;

- заходи із забезпечення незалежності суддів [15].

Бангалорські принципи поведінки суддів першим показником визначають незалежність судових органів, яка $\epsilon$ передумовою забезпечення правопорядку та основною гарантією справедливого вирішення справи в суді. Отже, суддя має відстоювати та втілювати в життя принцип незалежності судових органів в його індивідуальному та колективному аспектах. Застосовуючи цей принцип, суддя повинен здійснювати свою судову функцію незалежно, виходячи виключно 3 оцінювання фактів, відповідно до свідомого розуміння права, незалежно від стороннього впливу, спонукання, тиску, загроз чи втручання, прямого чи опосередкованого, що здійснюється 3 будь-якої сторони та з будь-якою метою; дотримуватися незалежної позиції як щодо суспільства загалом, так і щодо конкретних сторін судової справи, у якій він повинен винести рішення; не тільки виключає будь-які взаємовідносини, що не відповідають посаді, чи втручання 3 боку органів законодавчої та виконавчої влади, але й робить це так, щоб це було зрозуміло навіть сторонньому спостерігачу; коли рішення у справі має бути прийняте ним одноособово, він діє незалежно від своїх колег по суду; відстоює та підтримує гарантії виконання суддями своїх обов'язків задля збереження та підвищення інституціональної та оперативної відповідальності суддів; виявляє та підтримує високі стандарти поведінки суддів задля укріплення суспільної довіри до судових органів, що має першочергове значення для підтримки незалежності судових органів [8].

Незалежність суддів не є привілеєм чи прерогативою окремого судді. Це обов'язок, який покладається на кожного суддю для того, щоби дати йому можливість чесно та неупереджено розглядати справу на основі законів i доказів, без зовнішнього тиску чи впливу та побоювання будь-якого втручання. Основою принципу незалежності суддів $\epsilon$ повна свобода судді у розгляді справ, які надходять до суду; жоден зовнішній суб'єкт (уряд, групи впливу, окремі особи чи навіть інший суддя) не може втручатися чи здійснювати спробу втручання у ведення суддею справи i прийняття щодо неї рішення (Справа R v Beauregard, Верховний Суд Канади (1987 рік) LRC (Const) 180 at 188, виголошено Головним суддею Діксоном) [12].

Важливим у розгляді справи $\epsilon$ дотримання суддею принципу об'єктивності, який є необхідною умовою належного виконання ним своїх обов'язків. Об'єктивність проявляється не тільки у змісті винесеного рішення, але й в усіх процесуальних діях, що супроводжують його прийняття. Застосування відбувається таким чином:

- під час виконання своїх обов'язків суддя вільний від будь-яких схильностей, упередженості чи забобонів;

- поведінка судді в процесі засідання та за стінами суду має сприяти підтримці та зростанню довіри суспільства, представників юридичної професії та сторін у справі до об'єктивності суддів та судових органів;

- суддя за можливості обмежує себе у здійсненні дій, що можуть стати приводом для позбавлення його права брати участь у судовому засіданні та виносити рішення у справах;

- перед розглядом справи (про який відомо, що він відбудеться, або це 
тільки передбачається) суддя утримується від будь-яких коментарів, що могли би 3 огляду на розумне оцінювання ситуації якимось чином вплинути на перебіг цієї справи чи поставити під сумнів справедливе ведення процесу; суддя утримується від публічних та інших коментарів, оскільки це може перешкодити неупередженому розгляду справи стосовно певної особи чи питання;

- суддя заявляє про самовідвід від участі в розгляді справи в тому випадку, якщо для нього не є можливим винесення об'єктивного рішення у справі, або в тому випадку, коли у стороннього спостерігача могли б виникнути сумніви щодо неупередженості судді.

Нижче наведені приклади таких випадків:

- у судді склалося реальне упереджене ставлення до якоїсь зі сторін або судді 3 його власних джерел стали відомі певні докази чи факти стосовно справи, яка розглядається;

- раніше під час розгляду цього ж самого предмета спору суддя виступав як адвокат чи долучався до справи як важливий свідок;

- суддя чи члени його родини матеріально зацікавлені в рішенні у відповідній справі.

Суддя не може бути відсторонений від участі у розгляді справи тоді, коли жодний інший суд не може бути призначений для розгляду цієї справи або через терміновий характер справи, коли зволікання її вирішення може привести до серйозної судової помилки [8].

Стаття 75 Кримінального процесуального кодексу України (далі КПК) містить перелік обставин, що виключають участь слідчого судді, судді або присяжного в кримінальному провадженні, а саме пунктом 4 частини 1 статті 75 КПК визначено, що слідчий суддя, суддя або присяжний не може брати участь у кримінальному провадженні за наявності інших обставин, які викликають сумнів щодо його неупередженості [5].

Проте, на нашу думку, сумніви в неупередженості не варто порівнювати зі втручанням у судову діяльність як з боку сторін по справі, так i 3 боку 3MI, громадських організацій або окремих громадян. Тим більше, що в жодному нормативно-правому акті України не міститься посилання на заборону судді брати участь у розгляді справи, стосовно якої суддею було подано до ВРП або Генерального прокурора повідомлення про втручання в його діяльність як судді щодо здійснення правосуддя. Цей факт підкреслюе принцип забезпечення незмінюваності судді та/або складу суду як дотримання основної засади судочинства.

Щодо цього слушною слід вважати думку Голови Ради Суддів України О.С. Ткачука, який підкреслив, що Коментарем до Кодексу суддівської етики, затвердженим Рішенням Ради суддів України від 4 лютого 2016 року № 1, роз'яснено, що суддя має право заявити про самовідвід у випадках, передбачених процесуальним законодавством, за наявності упередженості щодо одного 3 учасників процесу. Відчуття упередженості - це формування у судді до тієї чи іншої людини, яка $є$ учасником судового розгляду, власного ставлення, заснованого не на об'єктивному критерії, а на особистих симпатіях або антипатіях. Проте він наголосив на тому, що слід розуміти, що зловживання самовідводом не допускається і може потягнути до застосування дисциплінарної відповідальності. У цьому контексті зловживання правом на самовідвід означає недобросовісне використання суддею незначного приводу для того, щоб уникнути розгляду справи, тому заявлення суддею самовідводу $\epsilon$ допустимим лише за неможливості ухвалення суддею об'єктивного рішення у справі [11].

Після факту втручання у діяльність суду, погроз, спроб впливу на суддю в різних проявах виникає гостра необхідність захисту судді, працівників 
суду, а також їх близьких та родичів.

Право на державний захист суддів та членів їхніх сімей закріплене статтею 140 ЗУ «Про судоустрій і статус суддів», яка визначає таке:

1) судді, члени їхніх сімей та їхнє майно перебувають під особливим захистом держави; Служба судової охорони, органи правопорядку зобов'язані вживати необхідних заходів для забезпечення безпеки судді, членів його сім'ї, збереження їхнього майна, якщо від судді надійде відповідна заява;

2) вчинені у зв'язку зі службовою діяльністю судді посягання на його життя й здоров'я, знищення чи пошкодження його майна, погроза вбивством, насильством чи пошкодженням майна судді, образа чи наклеп на нього, а також посягання на життя й здоров'я членів його сім'ї (батьків, дружини, чоловіка, дітей), погроза їм вбивством, пошкодженням майна мають наслідком відповідальність, установлену законом;

3) суддя має право на забезпечення засобами захисту, які йому надаються Службою судової охорони, утвореною відповідно до цього Закону [2].

Також державний захист суддів Конституційного Суду України, суддів та працівників апаратів судів, працівників правоохоронних органів здійснюється на підставі ЗУ «Про державний захист працівників суду і правоохоронних органів», який містить систему особливих заходів державного захисту від перешкоджання виконанню покладених на працівників суду та правоохоронних органів законом обов'язків і здійсненню наданих прав, а також від посягань на життя, здоров'я, житло й майно зазначених осіб та їх близьких родичів у зв'язку зі службовою діяльністю цих осіб [1].

Однак практика свідчить про недосконалість забезпечення носіїв судової влади безпечними умовами під час професійної діяльності та поза межами робочого місця, такими як особиста охорона, охорона житла та майна; видача зброї, засобів індивідуального захисту й сповіщення про небезпеку від протиправних дій, пов'язаних із судовою діяльністю.

Підтвердженням цієї проблеми стала доповідь члена ВРП А.А. Овсієнко, який підкреслив таке: «На жаль, досвід розгляду таких повідомлень протягом двох років діяльності ВРП засвідчує, що Генеральна прокуратура України та Національна поліція України i підпорядковані їм підрозділи не вживають достатньо ефективних заходів для швидкого досудового розслідування кримінальних проваджень за фактами втручання у здійснення правосуддя, адже дієве досудове розслідування $є$ найбільш ефективним засобом протидіï та попередження випадків втручання» [10].

На шляху до забезпечення в Україні незалежності судової гілки влади, верховенства права, права на справедливий та повноважний суд відповідно до європейських стандартів судочинства першочерговим завданням $€$ вирішення питань протидії злочинам проти правосуддя та забезпечення особистої безпеки життя та здоров'я носіїв судової влади, членів їхніх сімей, а також їхнього житла, майна. Дотримання державою цих умов під час здійснення правосуддя дало б змогу не лише вберегти суддів від фізичних посягань на їхне життя та здоров'я, але й захистити від розумового та психологічного навантаження, емоційної напруги, стресів та нервових зривів у разі незаконного впливу, тиску або втручання в їхню професійну діяльність.

\section{Література}

1. Про державний захист працівників суду і правоохоронних органів : Закон України від 23 грудня 1993 року № 3781-XII. URL : https ://zakon.rada.gov.ua/laws/show/3781-12.

2. Про судоустрій і статус суддів : Закон України від 2 червня 2016 року № 1402-VIII. URL : http ://zakon3.rada.gov.ua/laws/show/1402-19. 
3. Конституція України від 28 червня 1996 року. URL : http ://zakon.rada.gov.ua/laws/show/254к/96-вр.

4. Кримінальний кодекс України від 5 квітня 2001 року. URL : http ://zakon.rada.gov.ua/laws/show/2341-14.

5. Кримінальний процесуальний кодекс України від 13 квітня 2012 року. URL : http ://zakon5.rada.gov.ua/laws/show/4651-17.

6. Про незалежність судової влади : Постанова Пленуму Верховного Суду України від 13 червня 2007 року № 8. URL : https ://zakon.rada.gov.ua/laws/show/v0008700-07.

7. Рішення Конституційного Суду України у справі за конституційним поданням Верховного Суду України про офіційне тлумачення положень частин першої, другої статті 126 Конституції України та частини другої статті 13 Закону України «Про статус суддів» (справа про незалежність суддів як складову їхнього статусу). URL : https ://zakon.rada.gov.ua/laws/show/v019p710-04/ed20140302.

8. Бангалорські принципи поведінки суддів від 19 травня 2006 року, схвалені резолюцією економічної та соціальної Ради ООН 27 липня 2006 року. URL: https ://zakon.rada.gov.ua/laws/main/995_j67.

9. Городовенко В. В. Проблеми становлення незалежної судової влади в Україні : монографія. Київ : Фенікс, 2007. 224 с.

10. ГПУ та Нацполіція не вживають достатньо ефективних заходів для швидкого розслідування фактів втручання у здійснення правосуддя / Офіційний веб-сайт Вищої ради правосуддя. 2019. URL : http ://www.vru.gov.ua/news/4906.

11. Зловживання процесуальним правом на самовідвід може бути свідченням порушення вимог Кодексу суддівської етики / Офіційний веб-сайт Ради суддів України. 2019. URL : http ://rsu.gov.ua/ua/news/zlovzivanna-procesualnim-pravom-nasamovidvid-moze-buti-svidcennam-porusenna-vimog-kodeksu-suddivskoi-etiki.

12. Коментарі щодо Бангалорських принципів поведінки суддів. 2007. URL : http ://rsu.gov.ua/uploads/article/komentari-bangalorski-9818bfbb11.pdf.

13. Баулін Ю. В., Борисов В. І., Тютюгін В. І. та ін. Кримінальний кодекс України. Науково-практичний коментар : у 2 т. Т. 2 : Особлива частина. Київ, 2013. 1040 с.

14. Про результати діяльності Вищої ради правосуддя за 2018 рік / Вища рада правосуддя. 2018. URL : https ://hcj.gov.ua/statistics/informaciya-pro-rezultatydiyalnosti-vyshchoyi-rady-pravosuddya-za-2018-rik.

15. Химук А. В., Колотило М. О. Що $є$ і що не є втручанням у здійснення правосуддя? Фундація DeJuRe. URL : https ://dejure.foundation/longread/obstruction-of-justice-20162017.

\section{References}

1. "On state protection of court employees and law enforcement agencies": Law of Ukraine of 23.12.1993 No. 3781-XII. available at : https ://zakon.rada.gov.ua/laws/show/3781-12.

2. "On the Judiciary and Status of Judges" : Law of Ukraine of 02.06.2016 No. 1402-VIII. available at : http ://zakon3.rada.gov.ua/laws/show/1402-19.

3. "The Constitution of Ukraine of 28.06.1996", available at : http ://zakon.rada.gov.ua/laws/show/254k/96-ver. 
4. "The Criminal Code of Ukraine of April 05, 2001", available at : http ://zakon.rada.gov.ua/laws/show/2341-14.

5. "The Criminal Procedure Code of Ukraine of April 13, 2012", available at: http ://zakon5.rada.gov.ua/laws/show/4651-17.

6. "On the Independence of the Judiciary" : Resolution of the Plenum of the Supreme Court of Ukraine No. 8 of 13.06.2007, available at : https ://zakon.rada.gov.ua/laws/show/v0008700-07.

7. Decision of the Constitutional Court of Ukraine in the case on the constitutional submission of the Supreme Court of Ukraine on the official interpretation of the provisions of the first, second Article 126 of the Constitution of Ukraine and the second Article 13 of the Law of Ukraine "On the Status of Judges" (the case of the independence of judges as a component of their status), available at : https ://zakon.rada.gov.ua/laws/show/v019p71004/ed20140302.

8. "Bangalore Principles of Judicial Conduct of 19 May 2006", endorsed by UN Economic and Social Council resolution of 27 July 2006, available at : https ://zakon.rada.gov.ua/laws/main/995_j67.

9. Gorodovenko, V. V. (2007). Problemy stanovlennia nezalezhnoi sudovoi vlady v Ukraini : Monohrafiia [Problems of Independent Judiciary in Ukraine: Monograph]. Kyiv : Phoenix.

10. "The GPU and the National Police do not take sufficiently effective measures to promptly investigate the interference with the administration of justice", The official website of the High Council of Justice. 22.04.2019, available at : http ://www.vru.gov.ua/news/4906.

11. "Abuse of the right of recourse may be evidence of a violation of the requirements of the Code of Judicial Ethics", 06.12.2019, Official Website of the Council of Judges of Ukraine. available at : http ://rsu.gov.ua/en/news/zlovzivanna-procesual-pravu-nasamovidvid-moze-buti-svidcennam-porusenna-vimog-kodexsu-suddivskoi-etiki.

12. "Comments on Bangalore Principles of Judicial Conduct", 2007, available at: http ://rsu.gov.ua/uploads/article/comments-bangalore-9818bfbb11.pdf.

13. Baulin, Yu. V., Borisov, V. I., Tyutyugin V. I. Et al. (2013), Kryminalnyi kodeks Ukrainy. Naukovo-praktychnyi komentar: u 2 t. T. 2 : Osoblyva chastyna [The Criminal Code of Ukraine. Scientific and practical commentary : in 2 volumes], Vol. 2 : Special part, Kyiv, Ukraine.

14. "On the results of the activities of the High Council of Justice for 2018", Supreme Council of Justice. 2018, available at: https ://hcj.gov.ua/statistics/informaciya-pro-rezultatydiyalnosti-vyshchoyi-rady-pravosuddya-za-2018-rik.

15. Khimuk, A. V. and Kolotilo, M. O. "What is and is not an interference with the administration of justice?", DeJuRe Foundation, available at : https ://dejure.foundation/longread/obstruction-of-justice-2016-2017. 


\section{ІНФОРМАЦІЙНА ДОВІДКА ПРО АВТОРІВ}

Алімов Кирило Олександрович - к.ю.н., доцент, доцент кафедри цивільного права юридичного факультету Запорізького національного університету

Бондар Олександр Григорович - д.ю.н, доцент, професор кафедри цивільного права юридичного факультету, Перший проректор Запорізького національного університету

Войтович Свгеній Миколайович - к.ю.н., доцент, доцент кафедри кримінального права та правосуддя юридичного факультету Запорізького національного університету

Сна Ірина Вікторівна - к.ю.н., доцент кафедри кримінального права та правосуддя юридичного факультету Запорізького національного університету

Коломосць Тетяна Олександрівна - д.ю.н., професор, член-кореспондент НАПрН України, Заслужений юрист України, професор кафедри адміністративного та господарського права, декан юридичного факультету Запорізького національного університету

Кушнір Сергій Миколайович - д.ю.н., доцент, професор кафедри конституційного та трудового права юридичного факультету, проректор з навчально-виробничої роботи та матеріально-технічного забезпечення Запорізького національного університету

Ларкін Михайло Олександрович - к.ю.н., доцент, доцент кафедри кримінального права та правосуддя юридичного факультету Запорізького національного університету

Луц Дмитро Миколайович - к.ю.н., доцент кафедри цивільного права юридичного факультету Запорізького національного університету

Мельковський Олександр Вікторович - к.ю.н., доцент, доцент кафедри кримінального права та правосуддя юридичного факультету Запорізького національного університету

Пирожкова Юлія Володимирівна - д.ю.н., доцент, завідувач кафедри кримінального права та правосуддя юридичного факультету Запорізького національного університету

Самойленко Георгій Валерійович - к.ю.н., доцент, доцент кафедри цивільного права юридичного факультету Запорізького національного університету

Середа Анжела Миколаївна - к.і.н., доцент, доцент кафедри історії і теорії держави та права юридичного факультету Запорізького національного університету

Сінєльнік Руслан Васильович - к.ю.н., доцент, доцент кафедри кримінального права та правосуддя юридичного факультету Запорізького національного університету, суддя заводського району м. Запоріжжя

Ткалич Максим Олегович - к.ю.н., доцент, доцент кафедри цивільного права юридичного факультету Запорізького національного університету

Щипанова Ольга Олександрівна - к.ю.н., доцент, доцент кафедри цивільного права юридичного факультету Запорізького національного університету

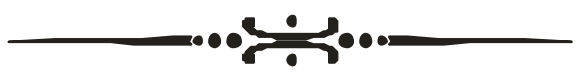


УДК

\section{ВИМОГИ ДО ОФОРМЛЕННЯ СТАТЕЙ У "ВІСНИК ЗАПОРІЗЬКОГО НАЦІОНАЛЬНОГО УНІВЕРСИТЕТУ" (СЕРІЯ „ЮРИДИЧНІ НАУКИ”)}

До друку приймаються наукові статті, де присутні такі необхідні елементи, передбачені п.3 Постанови президії ВАК України № 7-05/1 від 15 січня 2003 р. (Бюлетень ВАК України, № 1, 2003)

- Постановка проблеми у загальному вигляді та її зв'язок із важливими науковими чи практичними завданнями;

- Аналіз останніх досліджень і публікацій, в яких започатковано розв'язання даної проблеми і на які спирається автор;

- Виділення невирішених раніше частин загальної проблеми, котрим присвячується дана стаття;

- Формулювання цілей статті (постановка завдання);

- Виклад основного матеріалу дослідження 3 повним обгрунтуванням отриманих наукових результатів;

- Висновки з даного дослідження і перспективи подальших розвідок у даному напрямку.

\section{1. МАКЕТ СТОРІНКИ}

Для оригінал-макета використовується формат А4 з такими полями:

Верхнє та нижнє поля - 2 см, ліве поле -3 см, праве поле - 2 см, шрифт набору - “Times New Roman”,

14 кегль, міжрядковий інтервал - полуторний.

\section{2. ТИПОГРАФСЬКІ ПОГОДЖЕННЯ ТА СТИЛІ}

УДК набирається в першому рядкові сторінки і вирівнюється за лівим краєм. Заголовок статті набирається в наступному за УДК рядкові і вирівнюється посередині. Потім указують: прізвища, ініціали авторів, їх посади, учені ступені, звання, нижче - місие роботи (курсивом), адресу електронної пошти всіх або одного автора. Далі розташовуються анотації українською (3-5 речень) та англійською (1,5 сторінки) і ключові слова (також двома мовами). Анотації повинні також містити: прізвища, ініціали авторів, назву статті, місце їх роботи або навчання. Усі таблиці розташовуються у відповідних місцях тексту (по можливості угорі сторінки). Вони повинні бути послідовно пронумеровані: Таблиця 1, Таблиця 2, ... (слід використовувати арабську нумерацію). Надписи розташовуються над таблицями.

Посилання на літературні джерела подаються у квадратних дужках i послідовно нумеруються (слід використовувати арабську нумерацію) у порядку появи виноски в тексті статті [1, с. 1]. Перелік літературних джерел розташовується в порядку ї нумерації, в останньому розділі статті 3 підзаголовком: ЛІТЕРАТУРА, який розташовується по центру сторінки. Бібліографічний опис оформлюється згідно з ДСТУ 8302:2015 “інформація та документація. Бібліографічні посилання. Загальні положення та правила складання”. 3 наступного абзацу подається перелік літературних джерел латиницею (транслітерація) з підзаголовком REFERENCES, який вирівнюється по центру.

Для опублікування необхідно направити на адресу редакції юридичного факультету:

1. Роздрукований текст статті з анотаціями та ключовими словами українською та англійською мовами;

2. Відомості про авторів;

3. Витяг із протоколу засідання вченої ради факультету та рецензію наукового керівника (для аспірантів та здобувачів);

4. Диск, на якому повинно бути два файли: 1) із текстом статті та анотацій з ключовими словами; 2) iз відомостями про авторів (прізвище, ім'я, по батькові; посада; вчений ступінь; вчене звання; місце роботи або навчання; адреса електронної пошти; дом. адреса; номери контактних телефонів).

\section{Нагадуємо:}

До публікації приймаються статті, що відзначаються високим науковим рівнем підготовки, містять глибокий самостійний аналіз сучасних проблем розвитку науки та законодавства.

У статтях і повідомленнях висловлені погляди їхніх авторів, які не завжди збігаються з поглядами редакції.

Автор несе відповідальність за достовірність фактичних даних та інформації, що містяться в статтях, чіткість викладу тексту, цитування, а також за мовностилістичний рівень написання матеріалів.

Адреса редакції: Україна, 69600, м. Запоріжжя, МСП-41, вул. Жуковського, 66

Довідки за телефонами:

Відповідальний редактор - Лютіков Павло Сергійович - (061) 228-75-28

Відповідальний секретар - Шиванова Марина Григорівна - (061) 228-75-26

Електронна пошта: law_faculty_znu@ukr.net

Офіційний сайт: law.journalsofznu.zp.ua

Місце знаходження редакційної ради юридичного факультету: пр. Соборний, 74, Vкорпус, к. 101 
Збірник наукових праць

\section{Вісник Запорізького національного університету}

\section{Юридичні науки}

\section{№ 2, 2019}

Технічний редактор - М.Г. Шиванова

Підписано до друку 20.03.2014. Формат 60 x 90/8.

Папір Data Copy. Гарнітура “Таймс”.

Умовн.-друк. арк. 28,60

Замовлення №. 66 Наклад 100 прим.

Запорізький національний університет

69600, м. Запоріжжя, МСП-41

вул. Жуковського, 66

Свідоцтво про внесення суб' єкта видавничої справи до Державного реєстру видавців, виготівників

і розповсюджувачів видавничої продукції

ДК № 2952 від 30.08.2007 p. 